\title{
PIE on Safety-Tested AGR-1 Compact 5-1-1
}

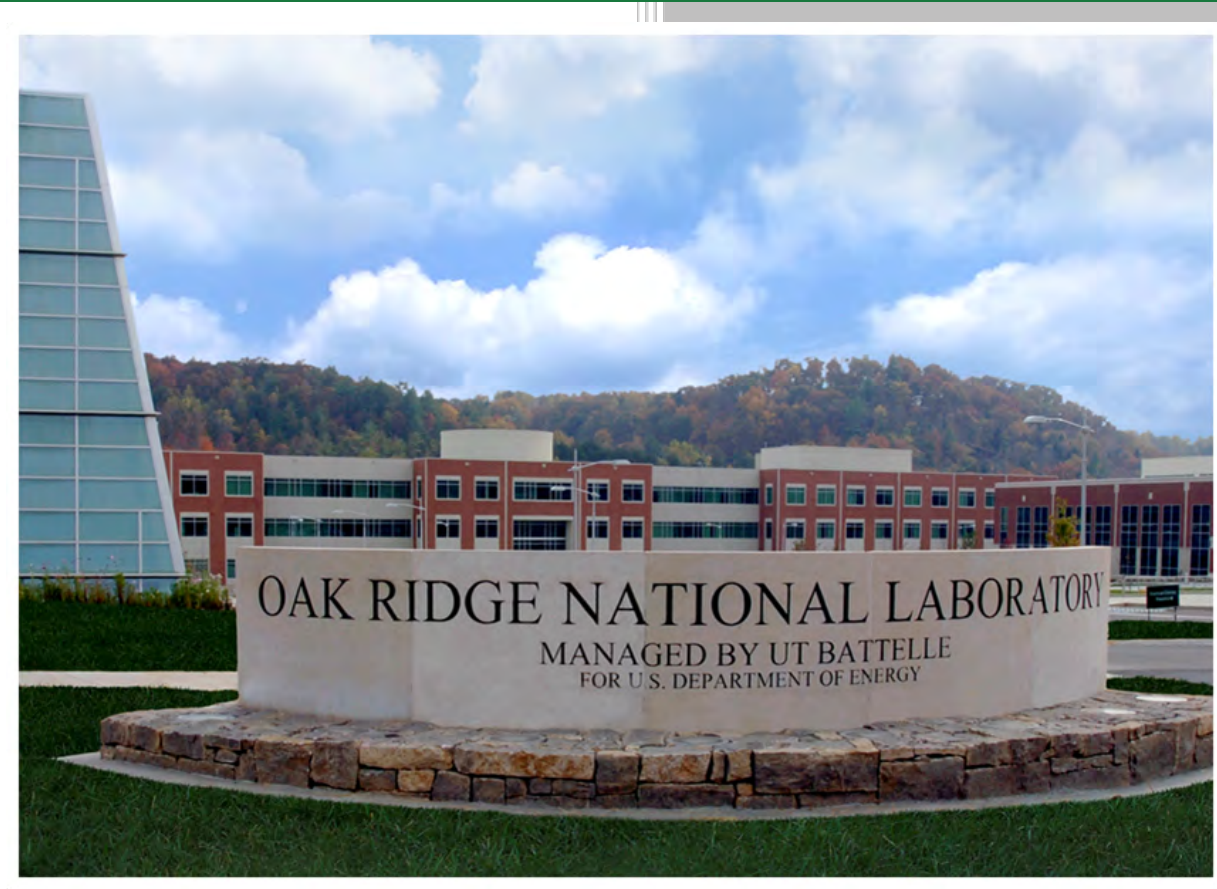

John D. Hunn

Robert N. Morris

Charles A. Baldwin

Fred C. Montgomery

Tyler J. Gerczak

August 2015

Approved for public release.

Distribution is unlimited. 


\title{
DOCUMENT AVAILABILITY
}

Reports produced after January 1, 1996, are generally available free via US Department of Energy (DOE) SciTech Connect.

\section{Website http://www.osti.gov/scitech/}

Reports produced before January 1, 1996, may be purchased by members of the public from the following source:

\author{
National Technical Information Service \\ 5285 Port Royal Road \\ Springfield, VA 22161 \\ Telephone 703-605-6000 (1-800-553-6847) \\ TDD 703-487-4639 \\ Fax 703-605-6900 \\ E-mail info@ntis.gov \\ Website http://www.ntis.gov/help/ordermethods.aspx
}

Reports are available to DOE employees, DOE contractors, Energy Technology Data Exchange representatives, and International Nuclear Information System representatives from the following source:

Office of Scientific and Technical Information

PO Box 62

Oak Ridge, TN 37831

Telephone 865-576-8401

Fax 865-576-5728

E-mail reports@osti.gov

Website http://www.osti.gov/contact.html

This report was prepared as an account of work sponsored by an agency of the United States Government. Neither the United States Government nor any agency thereof, nor any of their employees, makes any warranty, express or implied, or assumes any legal liability or responsibility for the accuracy, completeness, or usefulness of any information, apparatus, product, or process disclosed, or represents that its use would not infringe privately owned rights. Reference herein to any specific commercial product, process, or service by trade name, trademark, manufacturer, or otherwise, does not necessarily constitute or imply its endorsement, recommendation, or favoring by the United States Government or any agency thereof. The views and opinions of authors expressed herein do not necessarily state or reflect those of the United States Government or any agency thereof. 


\title{
PIE ON SAFETY-TESTED AGR-1 COMPACT 5-1-1
}

\author{
John D. Hunn \\ Robert N. Morris \\ Charles A. Baldwin \\ Fred C. Montgomery \\ Tyler J. Gerczak
}

Date Published: August 2015

\author{
Work sponsored by \\ US DEPARTMENT OF ENERGY \\ Office of Nuclear Energy - Advanced Reactor Technologies \\ under the \\ Advanced Gas Reactor Fuel Development and Qualification Program
}

Prepared by
OAK RIDGE NATIONAL LABORATORY

Oak Ridge, TN 37831-6283

managed by

UT-BATTELLE, LLC

for the

US DEPARTMENT OF ENERGY

under contract DE-AC05-00OR22725 



\section{TABLE OF CONTENTS}

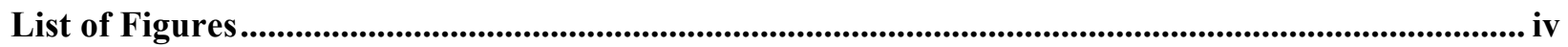

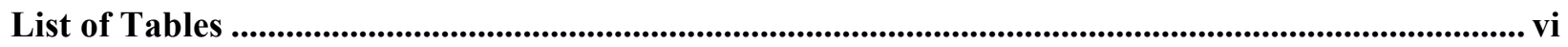

List of Acronyms ................................................................................................................................................... vii

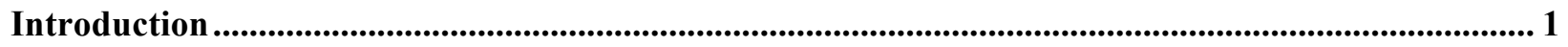

Safety Testing Results ...................................................................................................................................... 3

DLBL Results ................................................................................................................................................... 6

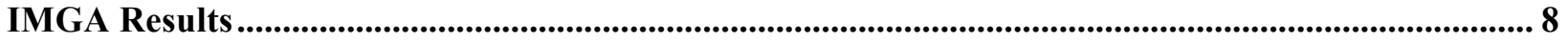

Microstructural Analysis of Individual Particles........................................................................................ 13

Analysis of particles that released cesium during safety testing ...................................................... 13

Analysis of particles specially-selected from the low-end tail of the $\mathrm{Cs} / \mathrm{Ce}$ distribution ...................... 23

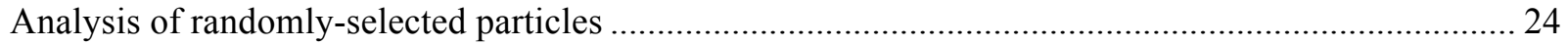

Enumeration of Particles with Failed SiC ...................................................................................................... 29

Summary and Conclusions.................................................................................................................................... 30

Acknowledgments ............................................................................................................................................... 31

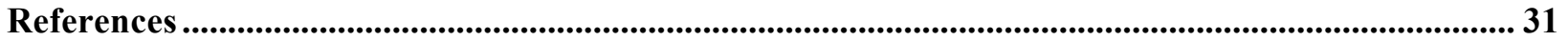




\section{LIST OF FIGURES}

Figure 1. Release of fission products from Compact 5-1-1 during safety testing to $1700^{\circ} \mathrm{C}$, plotted on a logarithmic scale.

Figure 2. Release of fission products from Compact 5-1-1 during safety testing to $1700^{\circ} \mathrm{C}$, plotted on a linear scale.

Figure 3. Release rates of fission products from Compact 5-1-1 during safety testing to $1700^{\circ} \mathrm{C}$.............. 4

Figure 4. Normalized ${ }^{144} \mathrm{Ce}$ activity in particles from Compact 5-1-1. Arrows show location of particles of interest.....

Figure 5. Normalized ${ }^{137} \mathrm{Cs}$ activity in particles from Compact 5-1-1. Arrows show location of particles of interest.

Figure 6. Estimated fraction of ${ }^{137} \mathrm{Cs}$ retained in particles from Compact 5-1-1, based on calculated inventory and adjusted for variation in fissionable material and burn-up using the measured ${ }^{144} \mathrm{Ce}$ activity. Arrows show location of particles of interest.

Figure 7. Ratio of ${ }^{110 \mathrm{~m}} \mathrm{Ag}$ retained in 45 particles randomly-selected from Compact 5-1-1. Note that the ${ }^{110 \mathrm{~m}} \mathrm{Ag}$ activity in these particles was very low at the time of analysis and uncertainty in peak analysis ranged from $30 \%$ for particles with more silver to $78 \%$ for particles with barely detectable silver. The 26 particles with undetectable inventory contained less than a minimum detectable $\mathrm{M} / \mathrm{C}$ of $<0.59-0.75$.

Figure 8. Low Cs/Ce Particle 3 (511-SP02): oblique orthogonal x-ray tomographs showing a gross $\mathrm{SiC}$ inclusion (pre-irradiation defect), and only residual kernel material remaining after preburn leaching.

Figure 9. Low-Cs/Ce Particle 1 (511-SP03): optical micrographs showing buffer and IPyC fracture, $\mathrm{IPyC} / \mathrm{SiC}$ delamination, kernel protrusion reaching the $\mathrm{SiC}$, and localized $\mathrm{SiC}$ degradation by palladium.

Figure 10. Low-Cs/Ce Particle 1 (511-SP03): optical micrograph showing same region as Figure 9 after additional polishing; a significant concentration of fission products can be seen in the OPyC layer, adjacent to the degraded SiC.

Figure 11. SEI/BEC-paired images of Low-Cs/Ce Particle 1 (511-SP03): a) particle overview, b) kernel protrusion adjacent to $\mathrm{SiC}$ degradation, and c) fission products filling IPyC crack.

Figure 12. Low-Cs/Ce Particle 1 (511-SP03): EDS elemental-intensity maps overlaid on SEI reference images of a) the large kernel protrusion near the degraded $\mathrm{SiC}$ region (Figure $11 \mathrm{~b}$ and e), and b) fission products in the IPyC crack shown in Figure 11c. U is not shown in (a) as its intensity limits observable details in $\mathrm{Mo}, \mathrm{Ru}$, and $\mathrm{Zr}$ distributions.

Figure 13. Low-Cs/Ce Particle 1 (511-SP03): EDS map of the IPyC crack with high-Z lining shown in Figure 11d.

Figure 14. Low-Cs/Ce Particle 1 (511-SP03): EDS maps of SiC degradation area (Figure 11d) showing distributions of the higher-concentration fission products.

Figure 15. Low-Cs/Ce Particle 2 (511-SP04): oblique orthogonal x-ray tomographs showing fractured buffer, kernel protrusion, partial buffer/IPyC delamination, and $\mathrm{SiC}$ degradation (identified by arrows).

Figure 16. Low-Cs/Ce Particle 2 (511-SP04): a) optical micrograph taken during grinding showing buffer fracture, incomplete buffer/IPyC delamination, IPyC crack at the edge of buffer/IPyC delamination, and localized $\mathrm{SiC}$ degradation; and b) optical micrograph of fully-polished plane showing same region, but just beyond point where the $\mathrm{SiC}$ degradation penetrated the layer.

Figure 17. SEI/BEC-paired images of Low-Cs/Ce Particle 2 (511-SP04): a) IPyC crack and SiC degradation area overview and b) closeup of the $\mathrm{SiC}$ degradation area.

Figure 18. Low-Cs/Ce Particle 2 (511-SP04) EDS map of SiC degradation area, element intensity is color coded and overlaid on the SEI reference image.

Figure 19. Orthogonal x-ray tomographs near midplane of Particle 511-SP17 (a and b), Particle 511-SP18 (c and d), and Particle 511-SP20 (e and f) showing typical buffer shrinkage and delamination from IPyC. 
Figure 20. Orthogonal tomographs near midplane of Particle 511-RS03 (a and b) and Particle 511RS05 (c and d) showing typical buffer shrinkage and delamination from IPyC.

Figure 21. Optical micrograph near midplane of Particle 511-RS09 showing typical buffer shrinkage and delamination from IPyC. Backpot epoxy (gray) embedded with some bright fragments of kernel debris from the grinding process can be seen filling the gap between the buffer and IPyC layers. The apparent variation in porosity in the $\mathrm{OPyC}$ layer is a polishing artifact.

Figure 22. Optical micrographs near midplane of Particle 511-RS04 showing buffer fracture and some tearing in the IPyC that did not appear to penetrate the layer......

Figure 23. SEI/BEC-paired images presenting an overview of the TRISO layers of a) Particle 511RS09 (M/C < 0.61), b) Particle 511-RS04 (M/C = 1.01), and c) Particle 511-RS37 (M/C = 1.48). Bright contrast between buffer and IPyC is from charging of backpot epoxy

Figure 24. SEI/BEC-paired images of the $\mathrm{SiC}$ layer of a) Particle 511-RS09 (M/C $<0.61), \mathrm{b})$ Particle 511-RS04 (M/C = 1.01), and c) Particle 511-RS37 (M/C = 1.48).

Figure 25. Backscattered-electron composition micrographs showing representative $\mathrm{IPyC} / \mathrm{SiC}$ regions from a) Particle 511-RS09 with high ${ }^{110 \mathrm{~m}} \mathrm{Ag}$ release $(\mathrm{M} / \mathrm{C}<0.61)$, and b) Particle 511-RS04 with low ${ }^{110 \mathrm{~m}} \mathrm{Ag}$ release $(\mathrm{M} / \mathrm{C}=1.01)$. Dashed diamonds or squares indicate relatively lower signal. 


\section{LIST OF TABLES}

Table 1. Summary of safety tests in ORNL CCCTF 1

Table 2. Cumulative releases of radioactive isotopes from Variant 1 fuel at the end of safety testing ....... 5

Table 3. Distribution of radioactive isotopes detected in the CCCTF furnace internals ........................... 6

Table 4. Isotopes detected at various stages of DLBL analysis ............................................................. 7

Table 5. Radioactive isotopes detected in randomly-selected and low $\mathrm{Cs} / \mathrm{Ce}$ particles from Compact

$$
5-1-1 . . .
$$

Table 6. Radioactive isotopes detected in specially-selected particles from lower end of Cs/Ce distribution.

Table 7. Enumeration of particles with failed $\mathrm{SiC}$ based on recovery of ${ }^{134} \mathrm{Cs}$ 


\section{LIST OF ACRONYMS}

$\begin{array}{ll}\text { AGR } & \text { Advanced Gas Reactor } \\ \text { ART } & \text { Advanced Reactor Technologies } \\ \text { ATR } & \text { Advanced Test Reactor } \\ \text { BEC } & \text { Backscattered-Electron Composition } \\ \text { CCCTF } & \text { Core Conduction Cooldown Test Facility } \\ \text { DLBL } & \text { Deconsolidation Leach-Burn-Leach } \\ \text { EDS } & \text { Energy Dispersive Spectroscopy } \\ \text { FIMA } & \text { Fissions per Initial Metal Atom } \\ \text { HTGR } & \text { High Temperature Gas-cooled Reactor } \\ \text { HFEF } & \text { Hot Fuel Examination Facility } \\ \text { IFEL } & \text { Irradiated Fuels Examination Laboratory (ORNL Building 3525) } \\ \text { IMGA } & \text { Irradiated Microsphere Gamma Analyzer } \\ \text { INL } & \text { Idaho National Laboratory } \\ \text { IPyC } & \text { Inner Pyrolytic Carbon (layer) } \\ \text { LEU } & \text { Low Enriched Uranium } \\ \text { M/C } & \text { Measured versus Calculated ratio } \\ \text { MTS } & \text { Methyltrichlorosilane } \\ \text { OPyC } & \text { Outer Pyrolytic Carbon (layer) } \\ \text { ORNL } & \text { Oak Ridge National Laboratory } \\ \text { PIE } & \text { Post-Irradiation Examination } \\ \text { RS } & \text { Randomly-Selected particles } \\ \text { SEI } & \text { Secondary-Electron Imaging } \\ \text { SEM } & \text { Scanning Electron Microscope } \\ \text { SiC } & \text { Silicon Carbide (layer) } \\ \text { SP } & \text { Specially-selected Particles } \\ \text { QC } & \text { Quality Control } \\ \text { TAVA } & \text { Time-Averaged/Volume-Averaged temperature } \\ \text { TRISO } & \text { TRistructural-ISOtropic (coated particles) } \\ \text { UCO } & \text { Uranium Carbide/uranium Oxide (kernels) } \\ \text { Z } & \text { Atomic number }\end{array}$





\section{INTRODUCTION}

Post-irradiation examination (PIE) is being performed in support of tristructural isotropic (TRISO) coated particle fuel development and qualification for High-Temperature Gas-cooled Reactors (HTGRs). AGR-1 was the first in a series of TRISO fuel irradiation experiments initiated in 2006 under the Advanced Gas Reactor (AGR) Fuel Development and Qualification Program; this work continues to be funded by the Department of Energy's Office of Nuclear Energy as part of the Advanced Reactor Technologies (ART) initiative. AGR-1 fuel compacts were fabricated at Oak Ridge National Laboratory (ORNL) in 2006 and irradiated for three years in the Idaho National Laboratory (INL) Advanced Test Reactor (ATR) to demonstrate and evaluate fuel performance under HTGR irradiation conditions. PIE is being performed at INL and ORNL to study how the fuel behaved during irradiation, and to examine fuel performance during exposure to elevated temperatures at or above temperatures that could occur during a depressurized conduction cooldown event. This report summarizes safety testing of irradiated AGR-1 Compact 5-1-1 in the ORNL Core Conduction Cooldown Test Facility (CCCTF) and post-safety testing PIE.

Compact 5-1-1 was the fourteenth and final CCCTF test of AGR-1 fuel. ORNL started the first AGR-1 post-irradiation compact safety test in 2011 and these tests continued through the end of 2014. Safety tests at ORNL were performed on AGR-1 Baseline, Variant 1, and Variant 3 fuel (Table 1). The AGR-1 Variant 1 particles were similar to AGR-1 baseline, with the exception that the inner pyrocarbon layer was deposited at $\sim 25^{\circ} \mathrm{C}$ higher temperature; this process change resulted in a lower average IPyC sink/float density $\left(1.853 \mathrm{~g} / \mathrm{cm}^{3}\right.$ compared to $\left.1.907 \mathrm{~g} / \mathrm{cm}^{3}\right)$. Variant 3 fuel employed the addition of an argon diluent to the hydrogen and methyltrichlorosilane (MTS) used to deposit the SiC layer. The addition of argon results in a finer-grained $\mathrm{SiC}$ microstructure that is deemed to be desirable for optimum fuel performance; this coating variation has been adopted as the standard for AGR production-scale coating.

Table 1. Summary of safety tests in ORNL CCCTF

\begin{tabular}{|c|c|c|c|c|c|}
\hline $\begin{array}{c}\text { ORNL } \\
\text { Test }\end{array}$ & $\begin{array}{l}\text { Compact } \\
\text { ID }\end{array}$ & Composite & $\begin{array}{c}\text { Safety Test } \\
\text { Temperature }\end{array}$ & $\begin{array}{c}\text { Safety Test } \\
\text { Summary Report }\end{array}$ & PIE Summary Report \\
\hline 1 & $6-4-3$ & Baseline & $1600^{\circ} \mathrm{C}$ & HTR2012-3-027 & \multirow{2}{*}{ ORNL/LTR-2012/397 } \\
\hline 2 & $3-3-2$ & Baseline & $1600^{\circ} \mathrm{C}$ & \multirow{3}{*}{ ORNL/LTR-2012/396 } & \\
\hline 3 & $3-2-2$ & Baseline & $1600^{\circ} \mathrm{C}$ & & ORNL/LTR-2012/928 \\
\hline 4 & $6-2-1$ & Baseline & $1600^{\circ} \mathrm{C}$ & & \multirow{3}{*}{ ORNL/LTR-2013/291 } \\
\hline 5 & $3-3-1$ & Baseline & $1700^{\circ} \mathrm{C}$ & ORNL/LTR-2012/926 & \\
\hline 7 & $4-4-1$ & Variant 3 & $1800^{\circ} \mathrm{C}$ & \multirow{3}{*}{ ORNL/LTR-2013/290 } & \\
\hline 6 & $4-1-2$ & Variant 3 & $1600^{\circ} \mathrm{C}$ & & \multirow{2}{*}{ ORNL/LTR-2014/101 } \\
\hline 8 & $4-4-3$ & Variant 3 & $1700^{\circ} \mathrm{C}$ & & \\
\hline 9 & $5-3-3$ & Variant 1 & $1600^{\circ} \mathrm{C}$ & \multirow{2}{*}{ ORNL/LTR-2013/603 } & \multirow{3}{*}{ ORNL/TM-2014/484 } \\
\hline 10 & $5-1-3$ & Variant 1 & $1800^{\circ} \mathrm{C}$ & & \\
\hline 11 & $3-2-3$ & Baseline & $1800^{\circ} \mathrm{C}$ & ORNL/TM-2014/484 & \\
\hline 12 & $4-2-2$ & Variant 3 & $1000-1600^{\circ} \mathrm{C}^{\mathrm{a}}$ & ORNL/LTR-2014/485 & ORNL/TM-2015/033 \\
\hline 13 & $4-4-2^{b}$ & Variant 3 & $1800^{\circ} \mathrm{C}$ & ORNL/LTR-2014/486 & ORNL/TM-2015/161 \\
\hline 14 & $5-1-1$ & Variant 1 & $1700^{\circ} \mathrm{C}$ & ORNL/TM-2015/317 & ORNL/TM-2015/317 \\
\hline
\end{tabular}

${ }^{\mathrm{a}}$ Compact 4-2-2 was tested at seven temperature from $1000-1600^{\circ} \mathrm{C}$.

${ }^{\mathrm{b}}$ Test was conducted using 75 TRISO particles deconsolidated from Compact 4-4-2.

Compact 5-1-1 was fabricated using AGR-1 Variant 1 TRISO fuel particles [Hunn and Lowden 2006], which contained 350- $\mu \mathrm{m}$-diameter kernels of mixed uranium carbide/uranium oxide (UCO) [Kercher and Hunn 2005]. The fabrication identification for Compact 5-1-1 was LEU01-47T-Z008; fabrication information and properties of the pre-irradiated compact are available in [Hunn, Montgomery, and Pappano 2006] and [Hunn, Savage, and Silva 2012]. 
AGR-1 Compact 5-1-1 was irradiated at the ATR to an average calculated burnup of $18.2 \%$ fissions per initial metal atom (FIMA) and an average calculated fast fluence of $3.76 \cdot 10^{25} \mathrm{n} / \mathrm{m}^{2}$, at a calculated timeaveraged and volume-averaged (TAVA) temperature of approximately $1041^{\circ} \mathrm{C}$. After capsule disassembly in the INL Hot Fuel Examination Facility (HFEF), metrology [Demkowicz et al. 2010] and gamma scanning [Harp 2013] were performed. The compact was then shipped to ORNL for safety testing and additional PIE. The Compact 5-1-1 safety test ran from December 9-23, 2014.

Irradiated Compact 5-1-1 was loaded into the CCCTF and heated in helium atmosphere to a temperature of $1700^{\circ} \mathrm{C}$, and held at that temperature for $300 \mathrm{~h}$ while monitoring for fission product release. After completion of the safety test, the compact was examined with a standard set of analyses that included the following: (1) detection of exposed fission products by Deconsolidation-Leach-Burn-Leach (DLBL), (2) measurement of the gamma-emitting isotopic inventory within individual particles with the ORNL Irradiated Microsphere Gamma Analyzer (IMGA), and (3) microstructural examination by highresolution x-ray tomography and materialography. The equipment and methods used for the safety testing and post-safety testing PIE were the same as those summarized in a recent report on similar tests performed on other AGR-1 compacts [Hunn et al. 2014-1] and have been described in detail in [Baldwin et al. 2012] and [Hunn et al. 2013-1]. In addition to standard imaging with a scanning electron microscope (SEM) and energy dispersive spectroscopy (EDS) for elemental analysis (as described in [Hunn et al. 2013-1]), a new Oxford X-Max 50 Silicon Drift Detector EDS system using AZtec acquisition software was used for elemental mapping. Secondary-electron imaging (SEI) and backscattered-election composition (BEC) imaging were used, with the two complimentary techniques conducted in parallel when possible.

\footnotetext{
${ }^{1}$ In this report, the term "fission product" is used in a general sense to refer to all the post-fission isotopes remaining at the end of the irradiation test. These include: isotopes directly generated by the fission process, isotopes generated by neutron activation, isotopes generated by radioactive decay, and residual uranium.
} 


\section{SAFETY TESTING RESULTS}

The time-dependent results of the Compact 5-1-1 safety test are shown in Figure 1 and Figure 2, using a logarithmic and linear scale, respectively. The plotted fractional release values are the cumulative amount of each fission product collected on the deposition cups, adjusted for radioactive decay and average collection efficiency, and divided by the predicted compact inventory for each fission product at the end of the irradiation [Sterbentz 2013]. Figure 3 shows the average release rate of the various isotopes for each deposition cup exchange period. The fission product release from Compact 5-1-1 during the $1700^{\circ} \mathrm{C}$ safety test was qualitatively similar to other AGR-1 safety tests.

Most of the silver was released as the compact was heated, followed by a significant decrease in the ${ }^{110 \mathrm{~m}} \mathrm{Ag}$ release rate after the first $1600^{\circ} \mathrm{C}$ cup change. No ${ }^{110 \mathrm{~m}} \mathrm{Ag}$ could be detected on the deposition cups after the cup change at 142 hours into the test due to the very low silver release during the later part of the test, coupled with the fact that the compact's ${ }^{110 \mathrm{~m}} \mathrm{Ag}$ inventory was nearly exhausted after 7.5 half lives since the end of the irradiation. Release of silver as compacts are heated to the safety test temperature has been observed in all the AGR-1 safety tests and is presumed to be dominated by release from the matrix and outer pyrolytic carbon (OPyC) of silver previously released through intact $\mathrm{SiC}$ during irradiation. Conversely, europium and strontium release rates increased over the first 100 hours at $1700^{\circ} \mathrm{C}$ and then were fairly constant throughout the remainder of the test. Based on DLBL data from as-irradiated compacts, this europium and strontium release is also thought to be dominated by slow release from the matrix and $\mathrm{OPyC}$, although additional diffusive release from $\mathrm{SiC}$ has not been ruled out and seems to be indicated by the safety testing results at $1800^{\circ} \mathrm{C}$ [Hunn et al. 2013-2, page 9; Hunn et al. 2014-1, page 7].

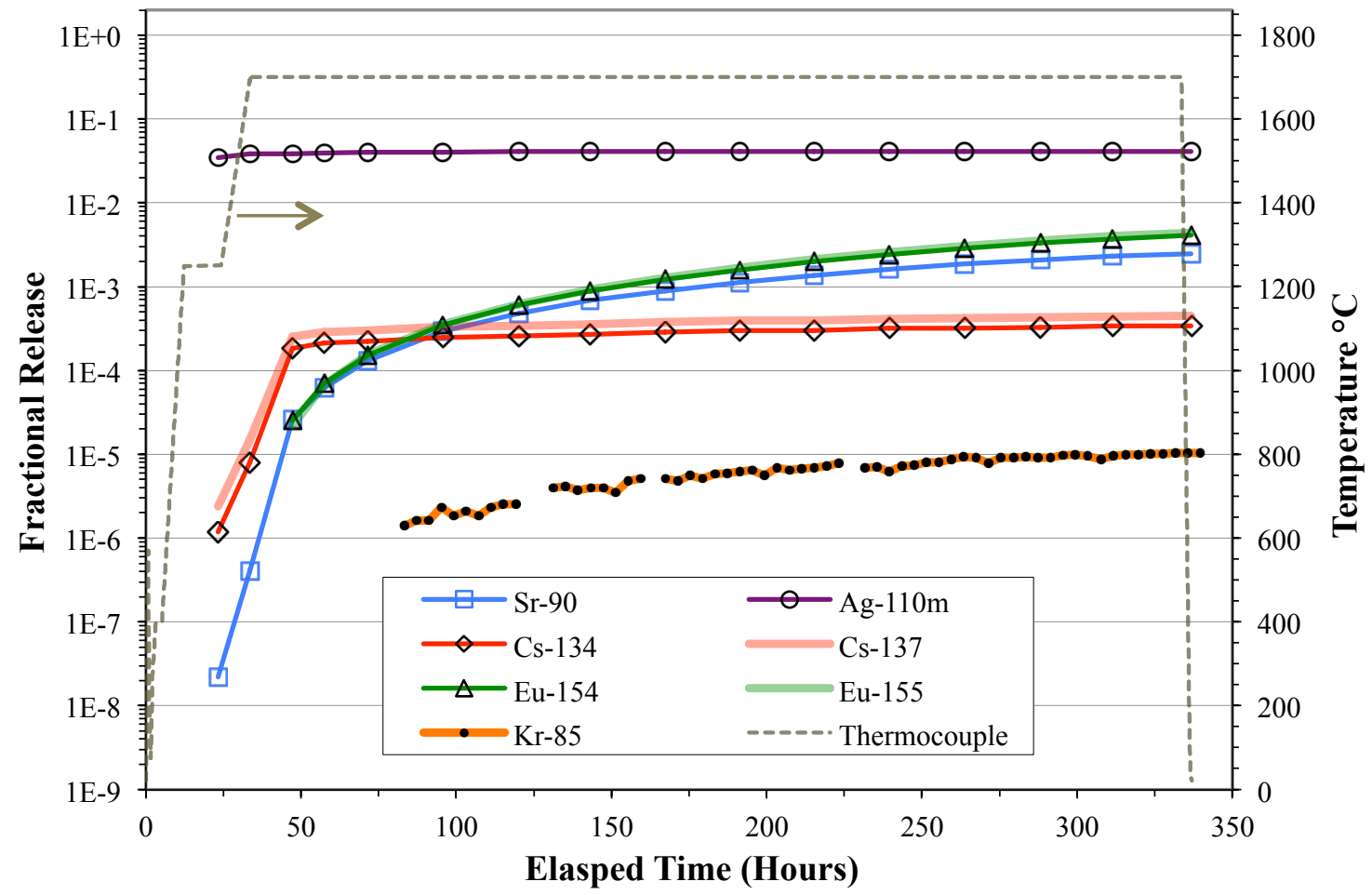

Figure 1. Release of fission products from Compact 5-1-1 during safety testing to $1700^{\circ} \mathrm{C}$, plotted on a logarithmic scale. 


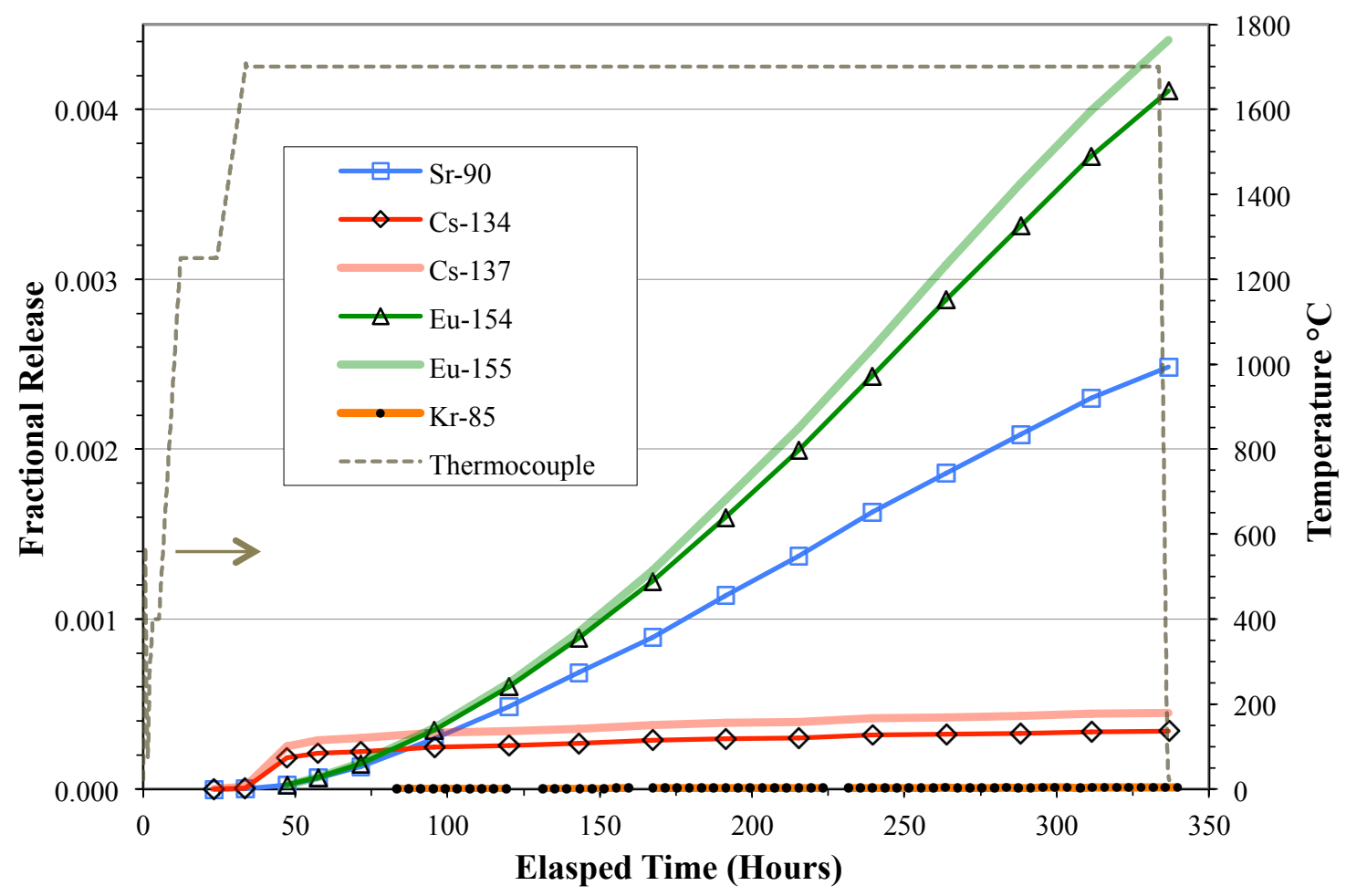

Figure 2. Release of fission products from Compact 5-1-1 during safety testing to $1700^{\circ} \mathrm{C}$, plotted on a linear scale.

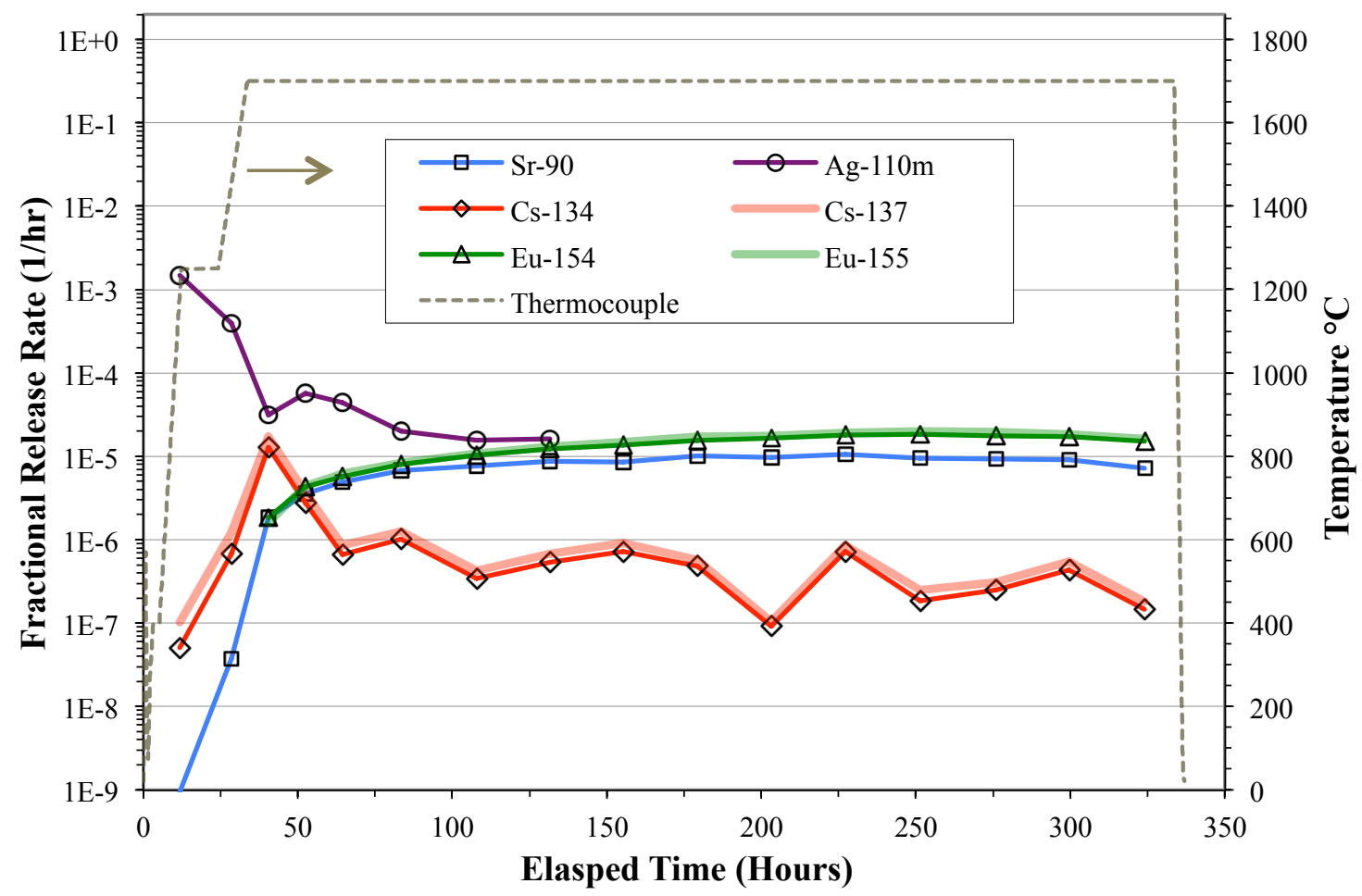

Figure 3. Release rates of fission products from Compact 5-1-1 during safety testing to $1700^{\circ} \mathrm{C}$.

The cesium release rate was highest during the 14-hour period immediately after reaching the $1700^{\circ} \mathrm{C}$ test temperature. The amount of cesium released during this period was typical for cesium release from two or three particles with failed SiC. After the initial burst of cesium release, the release rate dropped off by an 
order of magnitude and there was no additional significant increase in the release rate that would indicate additional $\mathrm{SiC}$ failure later in the test. The small increase in ${ }^{110 \mathrm{~m}} \mathrm{Ag}$ release rate on the cup following the peak cesium release rate may be from silver escaping through the failed $\mathrm{SiC}$. A slow release of krypton was observed that was well below the level that would indicate a failed TRISO coating, only reaching a cumulative fraction equivalent to a few percent of one particle's inventory. It is hypothesized that this krypton came from slow diffusion through the intact OPyC of the few particles that were releasing cesium. This type of krypton release has been observed in all the AGR-1 CCCTF safety tests at $1800^{\circ} \mathrm{C}$ (all of which had particles with failed $\mathrm{SiC}$ ) and in the $1700^{\circ} \mathrm{C}$ safety test of AGR-1 Compact 3-3-1 [Hunn et al. 2013-2, page 7], which also exhibited cesium release from particles with failed SiC.

Table 2 lists the total detected fission product releases at the end of the Compact 5-1-1 safety test, with a comparison to the other two safety-tested Variant 1 compacts irradiated in Capsule 5 [Hunn et al. 2014-1]. The magnitudes of the cumulative releases from Compact 5-1-1 were bracketed by the observed values for the other Variant 1 compacts tested at 1600 and $1800^{\circ} \mathrm{C}$. Compacts 5-1-1 and 5-1-3 were neighbors in the AGR-1 test train and experienced very similar irradiation conditions; therefore these compacts are expected to have very similar fission product distributions at the end of irradiation and comparison of the fission product release during safety testing provides some insight into the impact of the safety test temperature. Silver release was about the same for these two compacts, which is consistent with the presumption that silver release during safety testing is dominated by release from the matrix and OPyC of silver previously released through intact $\mathrm{SiC}$ during irradiation. Cesium and krypton releases were higher at $1800^{\circ} \mathrm{C}$, and this is related to the number of particles that experienced $\mathrm{SiC}$ failure during these safety tests. The average AGR-1 SiC failure fraction during safety testing increased as a function of temperature from $1600-1800^{\circ} \mathrm{C}$ [Hunn et al. 2014-2], and the three Capsule 5 compacts followed that trend. Higher strontium and europium release from Compact 5-1-3 at $1800^{\circ} \mathrm{C}$ is consistent with the conclusion that some measurable diffusion through intact $\mathrm{SiC}$ was occurring, and at a higher rate than in Compact 5-1-1 at $1700^{\circ} \mathrm{C}$.

Table 2. Cumulative releases of radioactive isotopes from Variant 1 fuel at the end of safety testing

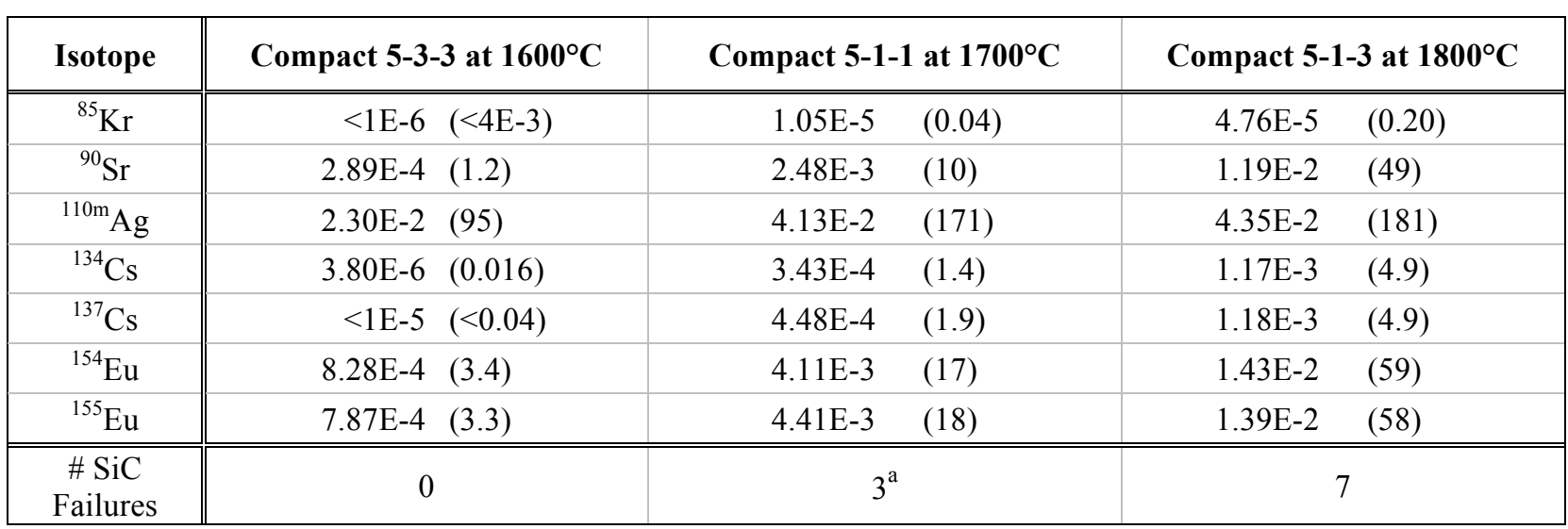

Release values are reported as a fraction of the calculated post-irradiation compact inventory [from Sterbentz 2013], with the equivalent number of exposed kernels shown in parentheses, which was calculated as the compact inventory fraction times the average number of particles in the compact (4150).

${ }^{\text {a }}$ As-discussed below, one of the Compact 5-1-1 SiC failures was due to an as-fabricated defect.

Table 3 shows the measured fraction of the various isotopes collected on the deposition cups. This collection efficiency was used to calculate the time-dependent fractional releases plotted above. Collection efficiency was uniformly low for the Compact 5-1-1 safety test; this is thought to be due to the combined effects of reduced heat transfer from the deposition cup to the cold finger and reduced cooling water flow through the furnace. Deposition cups used for this test had an inside radius that was contacting the bottom lip of the cold finger, which left a small gap between the bottom of the cold finger and the cup; measurements were made after the Compact 5-1-1 safety test that showed this gap resulted in a higher surface temperature on the deposition cup. Reduced cooling water flow to the furnace shell and 
flanges was due to a clogged outlet line. Silver and cesium collection efficiency in the CCCTF is usually much higher than was observed for the Compact 5-1-1 safety test (typically 90-100\%). Europium and strontium collection efficiencies tend to vary from test to test, and the efficiencies for the Compact 5-1-1 test were very similar to the $1600^{\circ} \mathrm{C}$ test of Compact 6-2-1 [Hunn et al. 2013-2, page 6]. Lower collection efficiencies can be expected to result in an increased uncertainty in the time-dependent results, but do not significantly affect the cumulative release data presented in Table 2.

Table 3. Distribution of radioactive isotopes detected in the CCCTF furnace internals

\begin{tabular}{|c|c|c|c|c|c|c|}
\hline Component & ${ }^{90} \mathrm{Sr}$ & ${ }^{110 \mathrm{~m}} \mathrm{Ag}$ & ${ }^{134} \mathrm{Cs}$ & ${ }^{137} \mathrm{Cs}$ & ${ }^{154} \mathbf{E u}$ & ${ }^{155} \mathbf{E u}$ \\
\hline Deposition cups & $18.4 \%$ & $34.2 \%$ & $12.4 \%$ & $10.8 \%$ & $9.9 \%$ & $8.3 \%$ \\
\hline Tantalum parts & $54.1 \%$ & $65.8 \%$ & $87.6 \%$ & $89.1 \%$ & $33.2 \%$ & $32.4 \%$ \\
\hline Graphite holder & $27.5 \%$ & $0 \%$ & $0 \%$ & $0 \%$ & $56.9 \%$ & $59.3 \%$ \\
\hline
\end{tabular}

\section{DLBL RESULTS}

Table 4 summarizes the results of the Compact 5-1-1 post-safety test DLBL analyses for some of the key isotopes generated by the irradiation test, and compares these results to those obtained after safety testing of Compacts 5-3-3 and 5-1-3. These results indicate how much of each isotope not contained within intact $\mathrm{SiC}$ was detected in the compacts before and after the burn step, where the burn step oxidizes exposed carbon and most exposed metallic elements not previously leached. Results are presented in terms of the compact inventory fraction and the equivalent number of exposed kernels (in parentheses). The compact inventory fraction was determined by dividing the measured amount of each isotope by the amount that was calculated to be in the fuel as a result of the three-year irradiation and subsequent radioactive decay, assuming no isotopic release during irradiation [Sterbentz 2013]. The equivalent number of exposed kernels was determined from the compact inventory fraction by multiplying by the average number of particles in each compact (4150 [Hunn, Savage, and Silva 2012]).

In Table 4, pre-burn data is presented in two parts. The first column of pre-burn data was obtained using the two standard pre-burn Soxhlet extractions [Hunn et al. 2013-1]. The second column of pre-burn data was obtained from analysis of the rinse solution collected after a water rinse of the particles and Soxhlet apparatus following the second pre-burn leach (and an additional alcohol rinse of the sieved particles for Compact 5-1-3). Post-burn data is given for matrix and particle leaching separately for the compacts that had failed $\mathrm{SiC}$, because these components had been separated by sieving to recover particles for IMGA survey.

Detection of uranium during DLBL is a good indicator for exposed kernels. If none of the TRISO layers in a particle are intact at the start of DLBL, then acid will dissolve uranium in the exposed kernel during the first pre-burn leach. If intact pyrocarbon protects the kernel from acid in a particle with failed $\mathrm{SiC}$, then uranium will not be dissolved in the pre-burn leaches, but the burn step will remove the pyrocarbon and expose the kernel to post-burn leaching. Compact 5-3-3 DLBL showed no indication of exposed kernels in pre-burn or post-burn leaching; this was in good agreement with the safety test results, where krypton and cesium releases were negligible, indicating no failed TRISO or failed SiC, respectively.

Based on the amount of cesium detected on the deposition cups and the absence of ${ }^{85} \mathrm{Kr}$ in the sweep gas, Compact 5-1-1 was expected to contain particles with failed $\mathrm{SiC}$ but at least one intact pyrocarbon layer. However, uranium from what appeared to be one exposed kernel was detected in the pre-burn and matrix post-burn solutions. This indicated that an OPyC layer on one of the particles with failed SiC may have broken during the deconsolidation/pre-burn leaching. A similar uranium release was detected during Compact 5-1-3 DLBL for the same reason. X-ray imaging of the Compact 5-1-1 particles with failed SiC (discussed below) confirms that one particle had broken OPyC. 
Table 4. Isotopes detected at various stages of DLBL analysis

\begin{tabular}{|c|c|c|c|c|c|c|c|c|c|c|c|c|}
\hline \multirow[b]{2}{*}{ Isotope } & \multirow{2}{*}{$\begin{array}{c}\text { Possible } \\
\text { Background } \\
\text { (upper limit) }\end{array}$} & \multicolumn{3}{|c|}{ Compact 5-3-3 $\left(1600^{\circ} \mathrm{C}\right)$} & \multicolumn{4}{|c|}{ Compact 5-1-1 $\left(1700^{\circ} \mathrm{C}\right)$} & \multicolumn{4}{|c|}{ Compact 5-1-3 $\left(1800^{\circ} \mathrm{C}\right)$} \\
\hline & & pre-burn & $\begin{array}{l}\text { rinse after } \\
\text { pre-burn }\end{array}$ & $\begin{array}{l}\text { combined } \\
\text { post-burn }\end{array}$ & pre-burn & $\begin{array}{l}\text { rinse after } \\
\text { pre-burn }\end{array}$ & $\begin{array}{c}\text { matrix } \\
\text { post-burn }\end{array}$ & $\begin{array}{c}\text { particle } \\
\text { post-burn }\end{array}$ & pre-burn & $\begin{array}{l}\text { rinse after } \\
\text { pre-burn }\end{array}$ & $\begin{array}{c}\text { matrix } \\
\text { post-burn }\end{array}$ & $\begin{array}{c}\text { particle } \\
\text { post-burn }\end{array}$ \\
\hline${ }^{90} \mathrm{Sr}$ & $\begin{array}{c}5 \mathrm{E}-7 \\
(0.002)\end{array}$ & $\begin{array}{c}3.17 \mathrm{E}-4 \\
(1.31)\end{array}$ & $\begin{array}{c}1.88 \mathrm{E}-6 \\
(0.008)\end{array}$ & $\begin{array}{c}3.43 \mathrm{E}-4 \\
(1.42)\end{array}$ & $\begin{array}{c}7.43 \mathrm{E}-4 \\
(3.08)\end{array}$ & $\begin{array}{c}2.01 \mathrm{E}-6 \\
(0.008)\end{array}$ & $\begin{array}{c}1.00 \mathrm{E}-4 \\
(0.42)\end{array}$ & $\begin{array}{c}2.29 \mathrm{E}-3 \\
(9.52)\end{array}$ & $\begin{array}{c}1.58 \mathrm{E}-4 \\
(0.65)\end{array}$ & $\begin{array}{c}4.00 \mathrm{E}-6 \\
(0.017)\end{array}$ & $\begin{array}{c}3.77 \mathrm{E}-5 \\
(0.16)\end{array}$ & $\begin{array}{c}3.51 \mathrm{E}-4 \\
(1.46)\end{array}$ \\
\hline${ }^{105} \mathrm{Pd}$ & $\begin{array}{l}3 \mathrm{E}-4 \\
(1.2)\end{array}$ & $\begin{array}{c}1.10 \mathrm{E}-4 \\
(0.45)\end{array}$ & $\begin{array}{c}<3.13 \mathrm{E}-5 \\
(<0.13)\end{array}$ & $\begin{array}{c}2.80 \mathrm{E}-5 \\
(0.12)\end{array}$ & $\begin{array}{c}1.40 \mathrm{E}-4 \\
(0.58)\end{array}$ & $\begin{array}{c}<2.26 \mathrm{E}-5 \\
(<0.09)\end{array}$ & $\begin{array}{c}<9.15 \mathrm{E}-4 \\
(<3.80)\end{array}$ & $\begin{array}{c}2.81 \mathrm{E}-5 \\
(0.12)\end{array}$ & $\begin{array}{c}3.03 \mathrm{E}-5 \\
(0.13)\end{array}$ & $\begin{array}{c}<2.50 \mathrm{E}-5 \\
(<0.10)\end{array}$ & $\begin{array}{c}<1.36 \mathrm{E}-3 \\
(<5.65)\end{array}$ & $\begin{array}{c}2.00 \mathrm{E}-4 \\
(0.83)\end{array}$ \\
\hline${ }^{106} \mathrm{Ru}$ & $\begin{array}{c}4 \mathrm{E}-7 \\
(0.002)\end{array}$ & $\begin{array}{c}1.48 \mathrm{E}-6 \\
(0.006)\end{array}$ & $\begin{array}{l}<1.12 \mathrm{E}-6 \\
(<0.005)\end{array}$ & $\begin{array}{c}9.59 \mathrm{E}-7 \\
(0.004)\end{array}$ & $\begin{array}{c}2.59 \mathrm{E}-5 \\
(0.11)\end{array}$ & $\begin{array}{c}1.80 \mathrm{E}-5 \\
(0.07)\end{array}$ & $\begin{array}{c}2.01 \mathrm{E}-5 \\
(0.08)\end{array}$ & $\begin{array}{c}<1.52 \mathrm{E}-5 \\
(<0.06)\end{array}$ & $\begin{array}{c}2.49 \mathrm{E}-6 \\
(0.010)\end{array}$ & $\begin{array}{c}8.92 \mathrm{E}-6 \\
(0.04)\end{array}$ & $\begin{array}{c}9.89 \mathrm{E}-5 \\
(0.41)\end{array}$ & $\begin{array}{c}<2.08 \mathrm{E}-5 \\
(<0.09)\end{array}$ \\
\hline${ }^{110 m} \mathrm{Ag}$ & $\begin{array}{l}<5 \mathrm{E}-5 \\
(<0.2)\end{array}$ & $\begin{array}{c}2.76 \mathrm{E}-4 \\
(1.15)\end{array}$ & $\begin{array}{c}<1.18 \mathrm{E}-4 \\
(<0.49)\end{array}$ & $\begin{array}{c}2.25 \mathrm{E}-4 \\
(0.93)\end{array}$ & $\begin{array}{c}<2.21 \mathrm{E}-3 \\
(<9.16)\end{array}$ & $\begin{array}{c}<4.14 \mathrm{E}-4 \\
(<1.72)\end{array}$ & $\begin{array}{c}<1.47 \mathrm{E}-3 \\
(<6.11)\end{array}$ & $\begin{array}{l}<2.71 \mathrm{E}-3 \\
(<11.25)\end{array}$ & $\begin{array}{c}<4.28 \mathrm{E}-4 \\
(<1.78)\end{array}$ & $\begin{array}{c}<1.51 \mathrm{E}-4 \\
(<0.63)\end{array}$ & $\begin{array}{c}<3.66 \mathrm{E}-4 \\
(<1.52)\end{array}$ & $\begin{array}{c}<1.79 \mathrm{E}-3 \\
(<7.44)\end{array}$ \\
\hline${ }^{125} \mathrm{Sb}$ & $\begin{array}{c}1 \mathrm{E}-6 \\
(0.004)\end{array}$ & $\begin{array}{c}<5.98 \mathrm{E}-6 \\
(<0.02)\end{array}$ & $\begin{array}{l}<2.90 \mathrm{E}-6 \\
(<0.012)\end{array}$ & $\begin{array}{c}<1.06 \mathrm{E}-5 \\
(<0.04)\end{array}$ & $\begin{array}{c}<1.37 \mathrm{E}-5 \\
(<0.06)\end{array}$ & $\begin{array}{c}<4.96 \mathrm{E}-6 \\
(<0.02)\end{array}$ & $\begin{array}{c}1.03 \mathrm{E}-5 \\
(0.04)\end{array}$ & $\begin{array}{c}<2.43 \mathrm{E}-5 \\
(<0.10)\end{array}$ & $\begin{array}{l}<6.75 \mathrm{E}-7 \\
(<0.003)\end{array}$ & $\begin{array}{c}1.38 \mathrm{E}-6 \\
(0.006)\end{array}$ & $\begin{array}{c}1.23 \mathrm{E}-5 \\
(0.05)\end{array}$ & $\begin{array}{c}6.98 \mathrm{E}-6 \\
(0.03)\end{array}$ \\
\hline${ }^{134} \mathrm{Cs}$ & $\begin{array}{c}2 \mathrm{E}-7 \\
(0.0008)\end{array}$ & $\begin{array}{l}3.72 \mathrm{E}-7 \\
(0.0015)\end{array}$ & $\begin{array}{c}7.85 \mathrm{E}-8 \\
(0.0003)\end{array}$ & $\begin{array}{c}2.53 \mathrm{E}-6 \\
(0.010)\end{array}$ & $\begin{array}{c}2.50 \mathrm{E}-6 \\
(0.010)\end{array}$ & $\begin{array}{c}3.46 \mathrm{E}-6 \\
(0.014)\end{array}$ & $\begin{array}{c}7.88 \mathrm{E}-6 \\
(0.03)\end{array}$ & $\begin{array}{c}4.30 \mathrm{E}-5 \\
(0.18)\end{array}$ & $\begin{array}{c}6.92 \mathrm{E}-6 \\
(0.03)\end{array}$ & $\begin{array}{c}2.11 \mathrm{E}-6 \\
(0.009)\end{array}$ & $\begin{array}{c}1.50 \mathrm{E}-5 \\
(0.06)\end{array}$ & $\begin{array}{c}5.36 \mathrm{E}-4 \\
(2.23)\end{array}$ \\
\hline${ }^{137} \mathrm{Cs}$ & $\begin{array}{c}6 \mathrm{E}-7 \\
(0.002)\end{array}$ & $\begin{array}{c}1.76 \mathrm{E}-6 \\
(0.007)\end{array}$ & $\begin{array}{c}6.84 \mathrm{E}-7 \\
(0.003)\end{array}$ & $\begin{array}{c}4.41 \mathrm{E}-6 \\
(0.018)\end{array}$ & $\begin{array}{c}5.58 \mathrm{E}-6 \\
(0.02)\end{array}$ & $\begin{array}{c}4.95 \mathrm{E}-6 \\
(0.02)\end{array}$ & $\begin{array}{c}1.17 \mathrm{E}-5 \\
(0.05)\end{array}$ & $\begin{array}{c}5.46 \mathrm{E}-5 \\
(0.23)\end{array}$ & $\begin{array}{c}9.95 \mathrm{E}-6 \\
(0.04)\end{array}$ & $\begin{array}{c}3.43 \mathrm{E}-6 \\
(0.014)\end{array}$ & $\begin{array}{c}2.34 \mathrm{E}-5 \\
(0.10)\end{array}$ & $\begin{array}{c}6.04 \mathrm{E}-4 \\
(2.50)\end{array}$ \\
\hline${ }^{144} \mathrm{Ce}$ & $\begin{array}{c}5 \mathrm{E}-7 \\
(0.002)\end{array}$ & $\begin{array}{c}1.01 \mathrm{E}-4 \\
(0.42)\end{array}$ & $\begin{array}{c}2.03 \mathrm{E}-6 \\
(0.008)\end{array}$ & $\begin{array}{c}3.70 \mathrm{E}-4 \\
(1.54)\end{array}$ & $\begin{array}{c}6.94 \mathrm{E}-4 \\
(2.88)\end{array}$ & $\begin{array}{c}5.04 \mathrm{E}-5 \\
(0.21)\end{array}$ & $\begin{array}{c}5.13 \mathrm{E}-4 \\
(2.13)\end{array}$ & $\begin{array}{c}4.31 \mathrm{E}-4 \\
(1.79)\end{array}$ & $\begin{array}{c}9.79 \mathrm{E}-4 \\
(4.06)\end{array}$ & $\begin{array}{c}1.04 \mathrm{E}-4 \\
(0.43)\end{array}$ & $\begin{array}{c}6.16 \mathrm{E}-4 \\
(2.56)\end{array}$ & $\begin{array}{c}2.03 \mathrm{E}-3 \\
(8.42)\end{array}$ \\
\hline${ }^{154} \mathrm{Eu}$ & $\begin{array}{c}3 \mathrm{E}-6 \\
(0.01)\end{array}$ & $\begin{array}{c}4.96 \mathrm{E}-4 \\
(2.06)\end{array}$ & $\begin{array}{l}<2.59 \mathrm{E}-6 \\
(<0.011)\end{array}$ & $\begin{array}{c}1.37 \mathrm{E}-3 \\
(5.68)\end{array}$ & $\begin{array}{c}1.32 \mathrm{E}-3 \\
(5.49)\end{array}$ & $\begin{array}{c}1.04 \mathrm{E}-5 \\
(0.04)\end{array}$ & $\begin{array}{c}1.09 \mathrm{E}-3 \\
(4.51)\end{array}$ & $\begin{array}{c}6.72 \mathrm{E}-4 \\
(2.79)\end{array}$ & $\begin{array}{c}1.80 \mathrm{E}-4 \\
(0.75)\end{array}$ & $\begin{array}{c}2.09 \mathrm{E}-6 \\
(0.009)\end{array}$ & $\begin{array}{c}1.31 \mathrm{E}-4 \\
(0.54)\end{array}$ & $\begin{array}{c}4.32 \mathrm{E}-4 \\
(1.79)\end{array}$ \\
\hline${ }^{155} \mathrm{Eu}$ & $\begin{array}{c}2 \mathrm{E}-6 \\
(0.01)\end{array}$ & $\begin{array}{c}5.41 \mathrm{E}-4 \\
(2.24)\end{array}$ & $\begin{array}{c}2.66 \mathrm{E}-6 \\
(0.011)\end{array}$ & $\begin{array}{c}1.50 \mathrm{E}-3 \\
(6.23)\end{array}$ & $\begin{array}{c}1.50 \mathrm{E}-3 \\
(6.22)\end{array}$ & $\begin{array}{c}1.01 \mathrm{E}-5 \\
(0.04)\end{array}$ & $\begin{array}{c}1.22 \mathrm{E}-3 \\
(5.07)\end{array}$ & $\begin{array}{c}\text { 7.67E-4 } \\
(3.18)\end{array}$ & $\begin{array}{c}1.49 \mathrm{E}-4 \\
(0.62)\end{array}$ & $\begin{array}{l}<2.83 \mathrm{E}-6 \\
(<0.012)\end{array}$ & $\begin{array}{c}1.06 \mathrm{E}-4 \\
(0.44)\end{array}$ & $\begin{array}{c}3.79 \mathrm{E}-4 \\
(1.57)\end{array}$ \\
\hline${ }^{235} \mathrm{U}$ & $\begin{array}{c}2 \mathrm{E}-6 \\
(0.01)\end{array}$ & $\begin{array}{c}6.47 \mathrm{E}-6 \\
(0.027)\end{array}$ & $\begin{array}{l}3.87 \mathrm{E}-7 \\
(0.0016)\end{array}$ & $\begin{array}{c}1.68 \mathrm{E}-5 \\
(0.070)\end{array}$ & $\begin{array}{c}1.03 \mathrm{E}-4 \\
(0.43)\end{array}$ & $\begin{array}{c}4.60 \mathrm{E}-5 \\
(0.19)\end{array}$ & $\begin{array}{c}1.28 \mathrm{E}-4 \\
(0.53)\end{array}$ & $\begin{array}{c}2.21 \mathrm{E}-5 \\
(0.09)\end{array}$ & $\begin{array}{c}\text { 7.99E-5 } \\
(0.33)\end{array}$ & $\begin{array}{c}1.89 \mathrm{E}-4 \\
(0.79)\end{array}$ & $\begin{array}{c}3.26 \mathrm{E}-5 \\
(0.14)\end{array}$ & $\begin{array}{c}9.76 \mathrm{E}-4 \\
(4.05)\end{array}$ \\
\hline${ }^{238} \mathrm{U}$ & $\begin{array}{c}3 E-6 \\
(0.01)\end{array}$ & $\begin{array}{c}7.71 \mathrm{E}-6 \\
(0.032)\end{array}$ & $\begin{array}{l}1.20 \mathrm{E}-6 \\
(0.005)\end{array}$ & $\begin{array}{c}2.01 \mathrm{E}-5 \\
(0.083)\end{array}$ & $\begin{array}{c}9.35 \mathrm{E}-5 \\
(0.39)\end{array}$ & $\begin{array}{c}3.86 \mathrm{E}-5 \\
(0.16)\end{array}$ & $\begin{array}{c}1.26 \mathrm{E}-4 \\
(0.52)\end{array}$ & $\begin{array}{c}2.73 \mathrm{E}-5 \\
(0.11)\end{array}$ & $\begin{array}{c}8.73 \mathrm{E}-5 \\
(0.36)\end{array}$ & $\begin{array}{c}1.79 \mathrm{E}-4 \\
(0.74)\end{array}$ & $\begin{array}{c}4.80 \mathrm{E}-5 \\
(0.20)\end{array}$ & $\begin{array}{c}1.11 \mathrm{E}-3 \\
(4.59)\end{array}$ \\
\hline${ }^{239} \mathrm{Pu}$ & $\begin{array}{c}2 \mathrm{E}-6 \\
(0.01)\end{array}$ & $\begin{array}{c}2.42 \mathrm{E}-5 \\
(0.10)\end{array}$ & $\begin{array}{c}8.56 \mathrm{E}-7 \\
(0.004)\end{array}$ & $\begin{array}{c}9.35 \mathrm{E}-5 \\
(0.39)\end{array}$ & $\begin{array}{c}1.32 \mathrm{E}-4 \\
(0.55)\end{array}$ & $\begin{array}{c}5.23 \mathrm{E}-6 \\
(0.02)\end{array}$ & $\begin{array}{c}1.33 \mathrm{E}-4 \\
(0.55)\end{array}$ & $\begin{array}{c}5.85 \mathrm{E}-5 \\
(0.24)\end{array}$ & $\begin{array}{c}2.61 \mathrm{E}-4 \\
(1.08)\end{array}$ & $\begin{array}{c}7.08 \mathrm{E}-6 \\
(0.03)\end{array}$ & $\begin{array}{c}1.40 \mathrm{E}-4 \\
(0.58)\end{array}$ & $\begin{array}{c}8.18 \mathrm{E}-4 \\
(3.39)\end{array}$ \\
\hline${ }^{240} \mathrm{Pu}$ & $\begin{array}{c}3 \mathrm{E}-6 \\
(0.01)\end{array}$ & $\begin{array}{c}5.18 \mathrm{E}-5 \\
(0.22)\end{array}$ & $\begin{array}{l}<7.24 \mathrm{E}-7 \\
(<0.003)\end{array}$ & $\begin{array}{c}2.15 \mathrm{E}-4 \\
(0.89)\end{array}$ & $\begin{array}{c}2.60 \mathrm{E}-4 \\
(1.08)\end{array}$ & $\begin{array}{c}5.94 \mathrm{E}-6 \\
(0.02)\end{array}$ & $\begin{array}{c}2.25 \mathrm{E}-4 \\
(0.93)\end{array}$ & $\begin{array}{c}1.41 \mathrm{E}-4 \\
(0.58)\end{array}$ & $\begin{array}{c}4.40 \mathrm{E}-4 \\
(1.82)\end{array}$ & $\begin{array}{c}6.46 \mathrm{E}-6 \\
(0.03)\end{array}$ & $\begin{array}{c}1.99 \mathrm{E}-4 \\
(0.83)\end{array}$ & $\begin{array}{c}9.29 \mathrm{E}-4 \\
(3.86)\end{array}$ \\
\hline
\end{tabular}

Values are reported as the fraction of compact inventory and the equivalent number of exposed kernels (in parentheses).

A " $<$ " indicates the measured signal was below a minimum detectable limit.

The detection limit for ${ }^{110 \mathrm{~m}} \mathrm{Ag}$ is elevated due to decay multiplier of 7.5-8 half-lives after the end of irradiation.

Numbers in gray are below estimated upper limits for possible background from hot cell contamination, determined by analysis of acid rinses as described in [Hunn et al. 2013-1]. 


\section{IMGA RESULTS}

After deconsolidation of Compacts 5-1-1, an IMGA survey of all available particles was performed using a 220-second counting time and the 35-cm detector geometry discussed in [Hunn et al. 2014-3, page 11] to look for individual particles that may have lost a significant fraction of cesium and been responsible for the observed cesium release in the CCCTF. Figure 4 and Figure 5 are histograms of the individualparticle ${ }^{134} \mathrm{Ce}$ and ${ }^{137} \mathrm{Cs}$ content normalized by the measured average, and Figure 6 is a histogram of the ${ }^{137} \mathrm{Cs}$ content plotted as the ratio of the measured versus calculated inventory adjusted for particle-toparticle variation in fissionable material and burn-up using the measured ${ }^{144} \mathrm{Ce}$ activity $(\mathrm{M} / \mathrm{C})$; these standard approaches for presenting IMGA results are described in [Hunn et al. 2013-1, pages 20-22]. The symmetric distributions around unity indicate that the typical particle retained ${ }^{134} \mathrm{Ce}$ and ${ }^{137} \mathrm{Cs}$ well, and the calculated ${ }^{137} \mathrm{Cs}$ inventory appears to be accurate to within a few percent. Figure 6 shows that Compact 5-1-1 had three particles with abnormally low ${ }^{137} \mathrm{Cs}$ retention; these can be seen populating bins to the left of the main distribution $(\mathrm{M} / \mathrm{C}<0.8)$. These three low-Cs/Ce particles were automatically sorted out during the IMGA survey and labeled as specially-selected particles (SP) for further analysis. Two of the low Cs/Ce particles had normal cerium content (Figure 4), as expected for a particle that has failed to retain cesium due to a through-layer degradation of the $\mathrm{SiC}$ layer. The third low $\mathrm{Cs} / \mathrm{Ce}$ particle had very low inventories for both cesium and cerium; this was due to the kernel being leached during the deconsolidation-leach process prior to IMGA survey. Another particle also had low inventories of both cerium and cesium (M/C of 0.22-0.24), but an above average $\mathrm{Cs} / \mathrm{Ce}$ ratio (Figure 6); similar particles have been observed in other AGR-1 compacts, and appear to have abnormally-low as-fabricated ${ }^{235} \mathrm{U}$ enrichment [Hunn et al. 2013-1, page 36]. A few other particles with normalized cesium and cerium activities outside the main distribution are not labeled in Figure 4 and Figure 5, and were not subjected to additional PIE, because their $\mathrm{Cs} / \mathrm{Ce}$ ratios were normal; these were probably particles with under-sized kernels. Pre-irradiation characterization of Variant 1 fuel found 20 out of 49799 particles $(\leq 5.9 \mathrm{E}-4$ at $95 \%$ confidence) had kernel diameters less than $300 \mu \mathrm{m}$ [Hunn, Montgomery, and Pappano 2006].

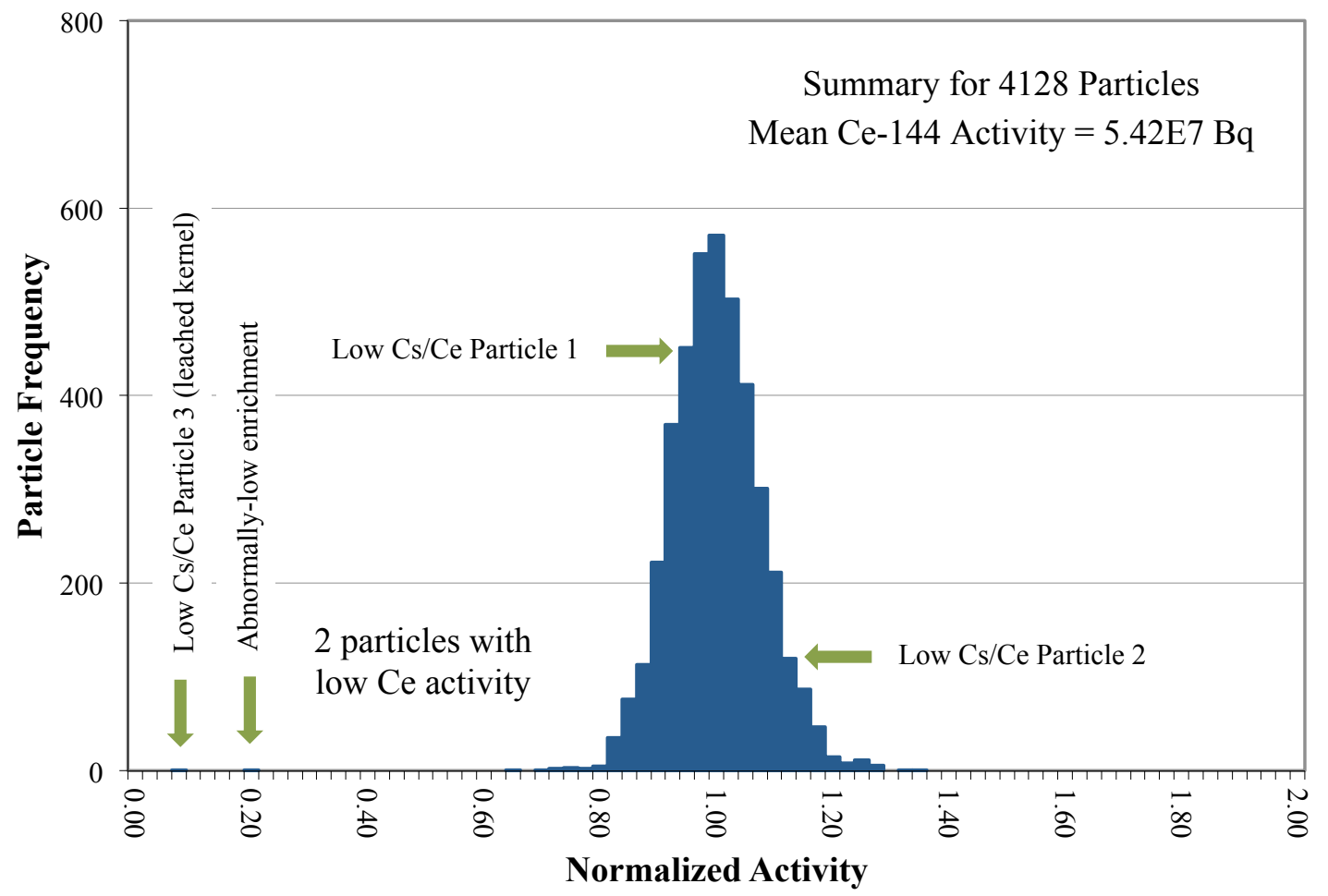

Figure 4. Normalized ${ }^{144} \mathrm{Ce}$ activity in particles from Compact 5-1-1. Arrows show location of particles of interest. 


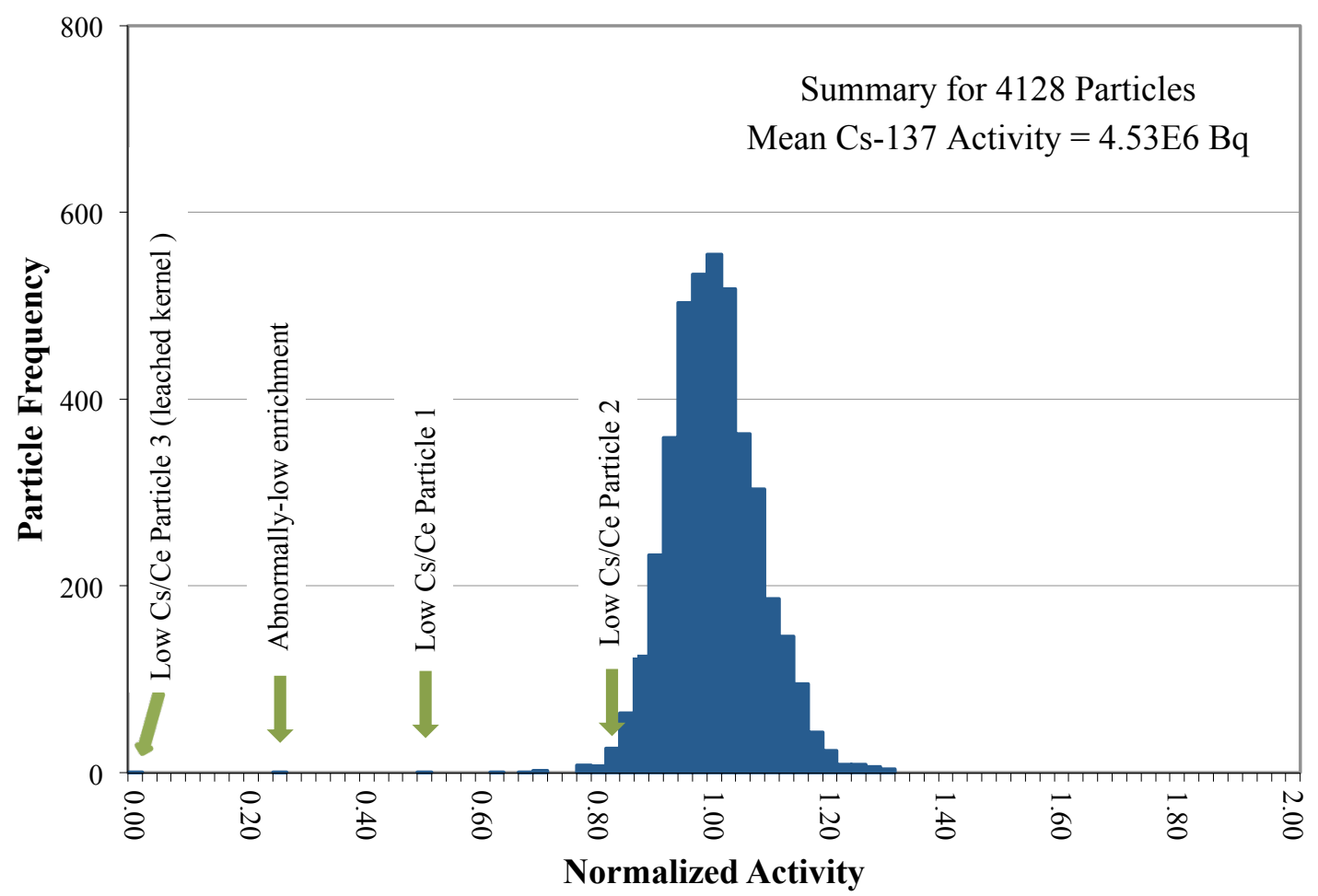

Figure 5. Normalized ${ }^{137} \mathrm{Cs}$ activity in particles from Compact 5-1-1. Arrows show location of particles of interest.

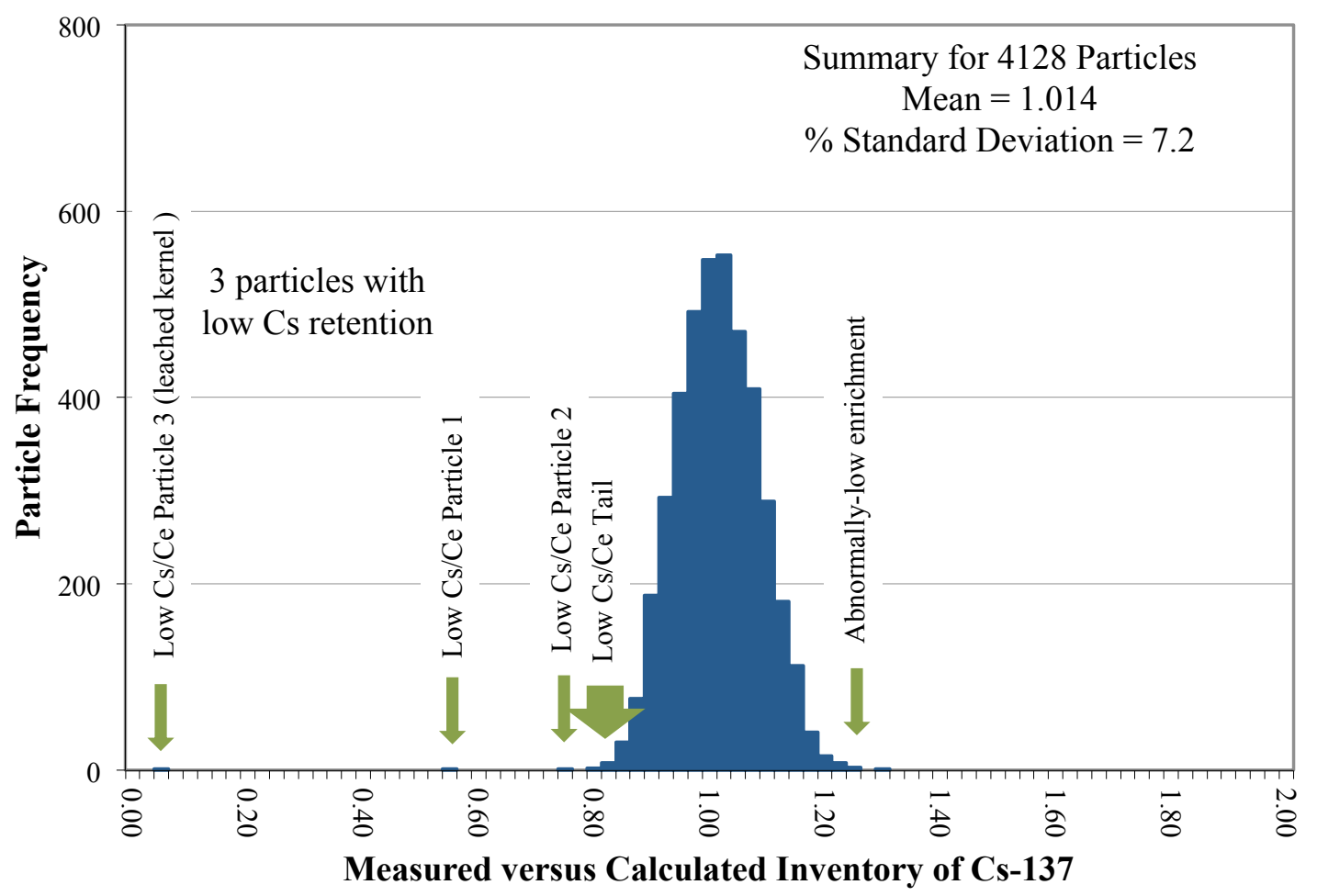

Figure 6. Estimated fraction of ${ }^{137} \mathrm{Cs}$ retained in particles from Compact 5-1-1, based on calculated inventory and adjusted for variation in fissionable material and burn-up using the measured ${ }^{144} \mathrm{Ce}$ activity. Arrows show location of particles of interest. 
In addition to the three low $\mathrm{Cs} / \mathrm{Ce}$ particles and one particle with low-fissile inventory, twenty particles were specially-selected for further analysis based on their below-average $\mathrm{Cs} / \mathrm{Ce}$ inventory; these particles appear in the low-end tail of Figure 6. The 24 specially-selected particles from Compacts 5-1-1, along with a sample of 45 randomly-selected particles (RS) were loaded into individual vials and subjected to 6hour gamma scanning. This longer scan time provided better quantitative analysis of the cesium and cerium content, and also allowed for analysis of other lower activity gamma-emitting isotopes, such as silver and europium. By handling particles in separate vials, the individual identity of each particle was maintained throughout the remainder of the PIE.

Table 5 show the average measured radioisotope activities in the 45 randomly-selected particles from Compact 5-1-1. All activities are decay-corrected to one day after the end of irradiation (11/07/2009 at 1200 GMT). The average measured inventories can be compared to the calculated inventories for an average particle in each compact (also provided in the table); values in parentheses are the ratios of the measured inventories to the average calculated inventories, but these ratios do not include the adjustment for variation in fissile material or burnup used in the IMGA histograms. The randomly-selected particles exhibited good retention of all measured radioisotopes except ${ }^{110 \mathrm{~m}} \mathrm{Ag}$ (which presumably was released through intact $\mathrm{SiC}$ during the irradiation test). The range in average activity for ${ }^{110 \mathrm{~m}} \mathrm{Ag}$ was calculated by assuming the particles with undetectable ${ }^{110 \mathrm{~m}} \mathrm{Ag}$ contained either zero silver (to establish the lower bound) or contained ${ }^{110 \mathrm{~m}} \mathrm{Ag}$ equal to the detection limit (to establish the upper bound). Figure 7 shows the distribution of measured ${ }^{110 \mathrm{~m}} \mathrm{Ag}$, with 26 particles having activities below the detection limit. Note however that the detection limit was extremely high $(<0.59-0.75)$ due to the $7.5-8$ half-lives that had passed since the end of the irradiation. The measured to calculated ratios for ${ }^{125} \mathrm{Sb}$ and ${ }^{154} \mathrm{Eu}$ were less than one, but this was due to a positive bias in the calculated inventories and does not represent measurable loss of these isotopes from the particles [Harp 2013].

Table 5. Radioactive isotopes detected in randomly-selected and low Cs/Ce particles from Compact 5-1-1

\begin{tabular}{|c||cc|c|c|c|c|c|}
\hline \multicolumn{1}{|c|}{} & \multicolumn{7}{|c|}{ Activity of select gamma-emitting isotopes in Bq/particle } \\
\cline { 2 - 9 } & ${ }^{\mathbf{1 0 6}} \mathbf{R u}$ & ${ }^{\mathbf{1 1 0} \mathbf{m} \mathbf{A g}}$ & ${ }^{\mathbf{1 2 5}} \mathbf{S b}$ & ${ }^{\mathbf{1 3 4}} \mathbf{C s}$ & ${ }^{\mathbf{1 3 7}} \mathbf{C s}$ & ${ }^{144} \mathbf{C e}$ & ${ }^{154} \mathbf{E u}$ \\
\hline \hline $\begin{array}{c}\text { Calculated inventory for an } \\
\text { average particle from 5-1-1 }\end{array}$ & $1.41 \mathrm{E} 7$ & $5.70 \mathrm{E} 4$ & $3.30 \mathrm{E} 5$ & $5.77 \mathrm{E} 6$ & $4.47 \mathrm{E} 6$ & $5.17 \mathrm{E} 7$ & $1.84 \mathrm{E} 5$ \\
\hline $\begin{array}{c}\text { Average measured inventory } \\
\text { of 45 random particles }\end{array}$ & $\begin{array}{c}1.39 \mathrm{E} 7 \\
(0.99)\end{array}$ & $\begin{array}{c}2.4-4.5 \mathrm{E} 4 \\
(0.42-0.79)\end{array}$ & $\begin{array}{c}2.26 \mathrm{E} 5 \\
(0.68)\end{array}$ & $\begin{array}{c}5.94 \mathrm{E} 6 \\
(1.03)\end{array}$ & $\begin{array}{c}4.54 \mathrm{E} 6 \\
(1.01)\end{array}$ & $\begin{array}{c}5.18 \mathrm{E} 7 \\
(1.00)\end{array}$ & $\begin{array}{c}1.56 \mathrm{E} 5 \\
(0.85)\end{array}$ \\
\hline $\begin{array}{c}\text { Percent standard deviation in } \\
\text { average measured inventory }\end{array}$ & 8.55 & & 6.41 & 9.38 & 5.91 & 5.13 & 9.63 \\
\hline $\begin{array}{c}\text { Low-Cs/Ce Particle 1 } \\
\text { (511-SP03) }\end{array}$ & $\begin{array}{c}1.55 \mathrm{E} 7 \\
(1.09)\end{array}$ & $\begin{array}{c}<2.20 \mathrm{E} 4 \\
(<0.39)\end{array}$ & $\begin{array}{c}2.45 \mathrm{E} 5 \\
(0.74)\end{array}$ & $\begin{array}{c}2.92 \mathrm{E} 6 \\
(0.51)\end{array}$ & $\begin{array}{c}2.30 \mathrm{E} 6 \\
(0.51)\end{array}$ & $\begin{array}{c}5.05 \mathrm{E} 7 \\
(0.98)\end{array}$ & $\begin{array}{c}5.82 \mathrm{E} 3 \\
(0.03)\end{array}$ \\
\hline $\begin{array}{c}\text { Low-Cs/Ce Particle 2 } \\
\text { (511-SP04) }\end{array}$ & $\begin{array}{c}1.40 \mathrm{E} 7 \\
(0.99)\end{array}$ & $\begin{array}{c}<3.01 \mathrm{E} 4 \\
(<0.53)\end{array}$ & $\begin{array}{c}2.41 \mathrm{E} 5 \\
(0.73)\end{array}$ & $\begin{array}{c}4.66 \mathrm{E} 6 \\
(0.81)\end{array}$ & $\begin{array}{c}3.76 \mathrm{E} 6 \\
(0.84)\end{array}$ & $\begin{array}{c}5.80 \mathrm{E} 7 \\
(1.12)\end{array}$ & $\begin{array}{c}1.17 \mathrm{E} 5 \\
(0.64)\end{array}$ \\
\hline $\begin{array}{c}\text { Low-Cs/Ce Particle 3 } \\
\text { (511-SP02) }\end{array}$ & $\begin{array}{c}5.96 \mathrm{E} 6 \\
(0.42)\end{array}$ & $\begin{array}{c}<1.26 \mathrm{E} 4 \\
(<0.22)\end{array}$ & $\begin{array}{c}1.89 \mathrm{E} 5 \\
(0.57)\end{array}$ & $\begin{array}{c}1.58 \mathrm{E} 4 \\
(0.003)\end{array}$ & $\begin{array}{c}1.30 \mathrm{E} 4 \\
(0.003)\end{array}$ & $\begin{array}{c}3.74 \mathrm{E} 6 \\
(0.07)\end{array}$ & $\begin{array}{c}<4.20 \mathrm{E} 2 \\
(<0.002)\end{array}$ \\
\hline
\end{tabular}

Values in parentheses are the measured/calculated ratios; highlighted cells indicate a measurable isotopic release.

Table 5 also lists the measured activities of the three low-cesium retention particles detected by IMGA, for comparison to the calculated inventories and average measured inventories in the randomly-selected particles. Low-Cs/Ce Particles 1 and 2 had normal inventories of ${ }^{106} \mathrm{Ru},{ }^{125} \mathrm{Sb}$, and ${ }^{144} \mathrm{Ce}$, but were low in ${ }^{110 \mathrm{~m}} \mathrm{Ag}$ and ${ }^{154} \mathrm{Eu}$, in addition to having released cesium. Low-Cs/Ce Particle 3 was low in all measured radioisotopes; this is clearly explained by the x-ray imaging discussed below, which showed that this particle was missing most if its kernel material. 
ORNL/TM-2015/317-R0

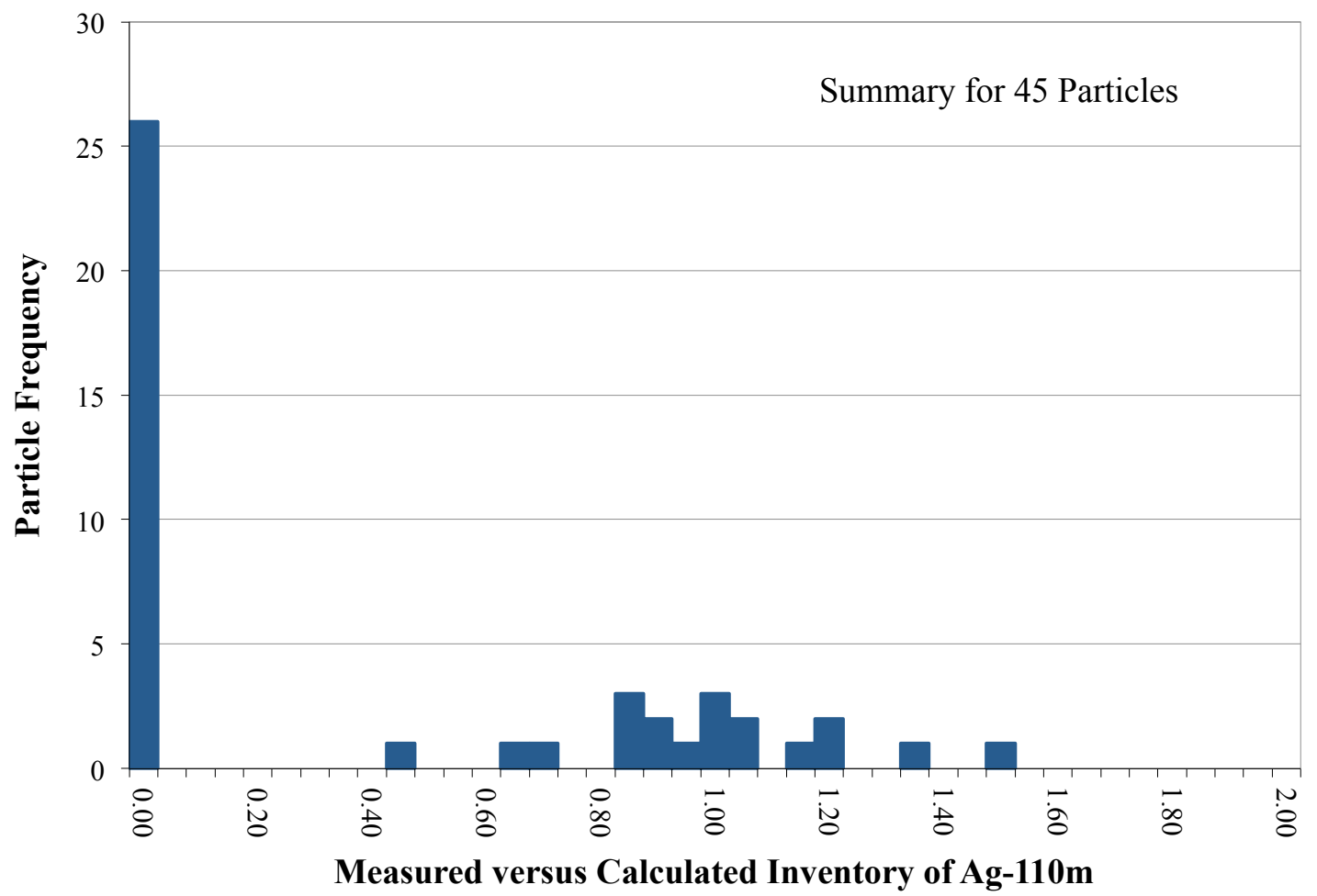

Figure 7. Ratio of ${ }^{110 \mathrm{~m}} \mathrm{Ag}$ retained in 45 particles randomly-selected from Compact 5-1-1. Note that the ${ }^{110 \mathrm{~m}} \mathrm{Ag}$ activity in these particles was very low at the time of analysis and uncertainty in peak analysis ranged from $30 \%$ for particles with more silver to $78 \%$ for particles with barely detectable silver. The 26 particles with undetectable inventory contained less than a minimum detectable $\mathrm{M} / \mathrm{C}$ of $<0.59-0.75$.

Table 6 lists the measured activities of the 20 particles from the low-end tail of the $\mathrm{Cs} / \mathrm{Ce}$ distribution shown in Figure 6. Comparison of the inventories in these 20 specially-selected particles to those in the 45-particle sample of randomly-selected particles shows that the 20 particles from the low-end tail tended to have below-average cesium and above-average cerium inventories, which combined to put them at the lower-end of the calculated ratio for ${ }^{137} \mathrm{Cs} /{ }^{144} \mathrm{Ce}$. The average measured ${ }^{106} \mathrm{Ru}$ and ${ }^{125} \mathrm{Sb}$ inventories in these particles were not significantly different than in the randomly-selected particles; however, the average ${ }^{154} \mathrm{Eu}$ inventory was also inexplicably lower. Three of the 20 specially-selected particles from the low-end tail of the $\mathrm{Cs} / \mathrm{Ce}$ distribution with the lowest measurable ${ }^{137} \mathrm{Cs} /{ }^{144} \mathrm{Ce}$ ratios $(\mathrm{SP} 17, \mathrm{SP} 18$, and SP20) were imaged with three-dimensional x-ray tomography, as discussed below, to look for any indication of $\mathrm{SiC}$ degradation that might explain the relatively-lower cesium and europium content; no $\mathrm{SiC}$ degradation was observed.

Prior to IMGA survey, all the particles recovered from each compact were imaged and counted. The total number of individual particles recovered from Compact 5-1-1 was 4149, which is in good agreement with the average Variant 1 particle loading of $4150 \pm 5$ determined as part of the quality control (QC) inspection for uranium dispersion in particles from twelve as-fabricated compacts [Hunn, Montgomery, and Pappano 2006-2]. The number of particles successfully gamma scanned with IMGA was 4128, indicating 21 particles were not scanned with IMGA, presumably due to loss during automated particle handling. Loss of particles during IMGA handling occurs when more than one particle is picked up by the vacuum needle, which sometimes results in particles being dropped between the storage vials and gamma counting station; optimization of the way the needle captures particles has minimized the occurrence of particles being dropped in this way, but has not been able to eliminate the possibility. Given that IMGA successfully identified three particles that released cesium and the residual inventory in these three particles added to the DLBL data matched the cesium release in the CCCTF (as discussed below), the fact that 21 particles were not surveyed by IMGA is not expected to impact the conclusions. 
Table 6. Radioactive isotopes detected in specially-selected particles from lower end of Cs/Ce distribution

\begin{tabular}{|c|c|c|c|c|c|c|c|}
\hline & \multicolumn{7}{|c|}{ Activity of select gamma-emitting isotopes in $\mathrm{Bq} /$ particle } \\
\hline & ${ }^{106} \mathrm{Ru}$ & ${ }^{110 m} \mathrm{Ag}$ & ${ }^{125} \mathrm{Sb}$ & ${ }^{134} \mathrm{Cs}$ & ${ }^{137} \mathrm{Cs}$ & ${ }^{144} \mathrm{Ce}$ & ${ }^{154} \mathbf{E u}$ \\
\hline $\begin{array}{l}\text { Average measured inventory } \\
\text { of } 45 \text { random particles }\end{array}$ & $\begin{array}{l}1.39 \mathrm{E} 7 \\
(0.99)\end{array}$ & $\begin{array}{c}2.4-4.5 \mathrm{E} 4 \\
(0.42-0.79)\end{array}$ & $\begin{array}{c}2.26 \mathrm{E} 5 \\
(0.68)\end{array}$ & $\begin{array}{l}5.94 \mathrm{E} 6 \\
(1.03)\end{array}$ & $\begin{array}{l}4.54 \mathrm{E} 6 \\
(1.01)\end{array}$ & $\begin{array}{l}5.18 \mathrm{E} 7 \\
(1.00)\end{array}$ & $\begin{array}{l}1.56 \mathrm{E} 5 \\
(0.85)\end{array}$ \\
\hline $\begin{array}{l}\text { Average measured inventory } \\
\text { Particles SP05-SP24 }\end{array}$ & $\begin{array}{l}1.33 \mathrm{E} 7 \\
(0.94)\end{array}$ & $\begin{array}{c}0.7-3.4 \mathrm{E} 4 \\
(0.12-0.59)\end{array}$ & $\begin{array}{l}2.20 \mathrm{E} 5 \\
(0.67)\end{array}$ & $\begin{array}{l}5.04 \mathrm{E} 6 \\
(0.87)\end{array}$ & $\begin{array}{l}4.28 \mathrm{E} 6 \\
(0.96)\end{array}$ & $\begin{array}{l}5.60 \mathrm{E} 7 \\
(1.08)\end{array}$ & $\begin{array}{l}1.35 \mathrm{E} 5 \\
(0.73)\end{array}$ \\
\hline $\begin{array}{l}\text { Particle from low-Cs/Ce tail } \\
\text { (511-SP05) }\end{array}$ & $\begin{array}{l}1.31 \mathrm{E} 7 \\
(0.93)\end{array}$ & $\begin{array}{l}0.00 \mathrm{E} 0 \\
(0.00)\end{array}$ & $\begin{array}{l}2.21 \mathrm{E} 5 \\
(0.67)\end{array}$ & $\begin{array}{l}5.45 \mathrm{E} 6 \\
(0.94)\end{array}$ & $\begin{array}{l}4.47 \mathrm{E} 6 \\
(1.00)\end{array}$ & $\begin{array}{l}5.48 \mathrm{E} 7 \\
(1.06)\end{array}$ & $\begin{array}{l}1.44 \mathrm{E} 5 \\
(0.78)\end{array}$ \\
\hline $\begin{array}{l}\text { Particle from low-Cs/Ce tail } \\
\text { (511-SP06) }\end{array}$ & $\begin{array}{l}1.25 \mathrm{E} 7 \\
(0.88)\end{array}$ & $\begin{array}{c}2.85 \mathrm{E} 4 \\
(0.50)\end{array}$ & $\begin{array}{l}2.18 \mathrm{E} 5 \\
(0.66)\end{array}$ & $\begin{array}{c}4.86 \mathrm{E} 6 \\
(0.84)\end{array}$ & $\begin{array}{l}4.14 \mathrm{E} 6 \\
(0.93)\end{array}$ & $\begin{array}{l}5.12 \mathrm{E} 7 \\
(0.99)\end{array}$ & $\begin{array}{l}1.20 \mathrm{E} 5 \\
(0.65)\end{array}$ \\
\hline $\begin{array}{l}\text { Particle from low-Cs/Ce tail } \\
\text { (511-SP07) }\end{array}$ & $\begin{array}{l}1.29 \mathrm{E} 7 \\
(0.91)\end{array}$ & $\begin{array}{c}0.00 \mathrm{E} 0 \\
(0.00)\end{array}$ & $\begin{array}{c}2.16 \mathrm{E} 5 \\
(0.65)\end{array}$ & $\begin{array}{l}4.97 \mathrm{E} 6 \\
(0.86)\end{array}$ & $\begin{array}{l}4.24 \mathrm{E} 6 \\
(0.95)\end{array}$ & $\begin{array}{l}5.41 \mathrm{E} 7 \\
(1.05)\end{array}$ & $\begin{array}{l}1.36 \mathrm{E} 5 \\
(0.74)\end{array}$ \\
\hline $\begin{array}{l}\text { Particle from low-Cs/Ce tail } \\
\text { (511-SP08) }\end{array}$ & $\begin{array}{l}1.44 \mathrm{E} 7 \\
(1.02)\end{array}$ & $\begin{array}{c}6.83 \mathrm{E} 4 \\
(1.20)\end{array}$ & $\begin{array}{c}2.37 \mathrm{E} 5 \\
(0.72)\end{array}$ & $\begin{array}{l}5.40 \mathrm{E} 6 \\
(0.94)\end{array}$ & $\begin{array}{l}4.69 \mathrm{E} 6 \\
(1.05)\end{array}$ & $\begin{array}{l}5.98 \mathrm{E} 7 \\
(1.16)\end{array}$ & $\begin{array}{c}1.34 \mathrm{E} 5 \\
(0.73)\end{array}$ \\
\hline $\begin{array}{l}\text { Particle from low-Cs/Ce tail } \\
\text { (511-SP09) }\end{array}$ & $\begin{array}{l}1.34 \mathrm{E} 7 \\
(0.95)\end{array}$ & $\begin{array}{c}0.00 \mathrm{E} 0 \\
(0.00)\end{array}$ & $\begin{array}{l}2.21 \mathrm{E} 5 \\
(0.67)\end{array}$ & $\begin{array}{c}5.29 \mathrm{E} 6 \\
(0.92)\end{array}$ & $\begin{array}{l}4.38 \mathrm{E} 6 \\
(0.98)\end{array}$ & $\begin{array}{l}5.65 \mathrm{E} 7 \\
(1.09)\end{array}$ & $\begin{array}{c}1.39 \mathrm{E} 5 \\
(0.76)\end{array}$ \\
\hline $\begin{array}{l}\text { Particle from low-Cs/Ce tail } \\
\text { (511-SP10) }\end{array}$ & $\begin{array}{l}1.33 \mathrm{E} 7 \\
(0.94)\end{array}$ & $\begin{array}{c}0.00 \mathrm{E} 0 \\
(0.00)\end{array}$ & $\begin{array}{r}2.21 \mathrm{E} 5 \\
(0.67)\end{array}$ & $\begin{array}{c}5.31 \mathrm{E} 6 \\
(0.92)\end{array}$ & $\begin{array}{c}4.40 \mathrm{E} 6 \\
(0.98)\end{array}$ & $\begin{array}{l}5.72 \mathrm{E} 7 \\
(1.10)\end{array}$ & $\begin{array}{l}1.43 \mathrm{E} 5 \\
(0.78) \\
\end{array}$ \\
\hline $\begin{array}{l}\text { Particle from low-Cs/Ce tail } \\
\text { (511-SP11) }\end{array}$ & $\begin{array}{l}1.35 \mathrm{E} 7 \\
(0.96)\end{array}$ & $\begin{array}{c}0.00 \mathrm{E} 0 \\
(0.00)\end{array}$ & $\begin{array}{c}2.23 \mathrm{E} 5 \\
(0.67) \\
\end{array}$ & $\begin{array}{c}5.32 \mathrm{E} 6 \\
(0.92) \\
\end{array}$ & $\begin{array}{c}4.52 \mathrm{E} 6 \\
(1.01) \\
\end{array}$ & $\begin{array}{l}5.72 \mathrm{E} 7 \\
(1.11) \\
\end{array}$ & $\begin{array}{l}1.28 \mathrm{E} 5 \\
(0.70) \\
\end{array}$ \\
\hline $\begin{array}{l}\text { Particle from low-Cs/Ce tail } \\
\text { (511-SP12) }\end{array}$ & $\begin{array}{l}1.40 \mathrm{E} 7 \\
(0.99)\end{array}$ & $\begin{array}{l}4.07 \mathrm{E} 4 \\
(0.71)\end{array}$ & $\begin{array}{l}2.27 \mathrm{E} 5 \\
(0.69)\end{array}$ & $\begin{array}{l}4.97 \mathrm{E} 6 \\
(0.86)\end{array}$ & $\begin{array}{l}4.41 \mathrm{E} 6 \\
(0.99)\end{array}$ & $\begin{array}{l}5.79 \mathrm{E} 7 \\
(1.12)\end{array}$ & $\begin{array}{l}1.35 \mathrm{E} 5 \\
(0.74)\end{array}$ \\
\hline $\begin{array}{l}\text { Particle from low-Cs/Ce tail } \\
\text { (511-SP13) }\end{array}$ & $\begin{array}{l}1.17 \mathrm{E} 7 \\
(0.83)\end{array}$ & $\begin{array}{l}0.00 \mathrm{E} 0 \\
(0.00)\end{array}$ & $\begin{array}{l}1.92 \mathrm{E} 5 \\
(0.58)\end{array}$ & $\begin{array}{l}4.58 \mathrm{E} 6 \\
(0.79)\end{array}$ & $\begin{array}{l}3.86 \mathrm{E} 6 \\
(0.86)\end{array}$ & $\begin{array}{l}5.35 \mathrm{E} 7 \\
(1.03)\end{array}$ & $\begin{array}{c}1.25 \mathrm{E} 5 \\
(0.68)\end{array}$ \\
\hline $\begin{array}{l}\text { Particle from low-Cs/Ce tail } \\
\text { (511-SP14) }\end{array}$ & $\begin{array}{l}1.34 \mathrm{E} 7 \\
(0.94)\end{array}$ & $\begin{array}{l}0.00 \mathrm{E} 0 \\
(0.00)\end{array}$ & $\begin{array}{l}2.26 \mathrm{E} 5 \\
(0.68)\end{array}$ & $\begin{array}{l}5.20 \mathrm{E} 6 \\
(0.90)\end{array}$ & $\begin{array}{l}4.44 \mathrm{E} 6 \\
(0.99)\end{array}$ & $\begin{array}{l}5.97 \mathrm{E} 7 \\
(1.15)\end{array}$ & $\begin{array}{l}1.41 \mathrm{E} 5 \\
(0.77)\end{array}$ \\
\hline $\begin{array}{l}\text { Particle from low-Cs/Ce tail } \\
(511-\mathrm{SP} 15)\end{array}$ & $\begin{array}{l}1.31 \mathrm{E} 7 \\
(0.93) \\
\end{array}$ & $\begin{array}{c}0.00 \mathrm{E} 0 \\
(0.00)\end{array}$ & $\begin{array}{c}2.08 \mathrm{E} 5 \\
(0.63) \\
\end{array}$ & $\begin{array}{c}4.59 \mathrm{E} 6 \\
(0.80) \\
\end{array}$ & $\begin{array}{c}4.08 \mathrm{E} 6 \\
(0.91) \\
\end{array}$ & $\begin{array}{l}5.46 \mathrm{E} 7 \\
(1.05)\end{array}$ & $\begin{array}{r}1.28 \mathrm{E} 5 \\
(0.69) \\
\end{array}$ \\
\hline $\begin{array}{l}\text { Particle from low-Cs/Ce tail } \\
\text { (511-SP16) }\end{array}$ & $\begin{array}{l}1.28 \mathrm{E} 7 \\
(0.91)\end{array}$ & $\begin{array}{c}0.00 \mathrm{E} 0 \\
(0.00)\end{array}$ & $\begin{array}{c}2.10 \mathrm{E} 5 \\
(0.64)\end{array}$ & $\begin{array}{l}5.02 \mathrm{E} 6 \\
(0.87)\end{array}$ & $\begin{array}{l}4.16 \mathrm{E} 6 \\
(0.93)\end{array}$ & $\begin{array}{l}5.22 \mathrm{E} 7 \\
(1.01)\end{array}$ & $\begin{array}{c}1.35 \mathrm{E} 5 \\
(0.73)\end{array}$ \\
\hline $\begin{array}{l}\text { Particle from low-Cs/Ce tail } \\
\text { (511-SP17) }\end{array}$ & $\begin{array}{l}1.24 \mathrm{E} 7 \\
(0.88) \\
\end{array}$ & $\begin{array}{l}0.00 \mathrm{E} 0 \\
(0.00)\end{array}$ & $\begin{array}{l}2.16 \mathrm{E} 5 \\
(0.65) \\
\end{array}$ & $\begin{array}{l}4.34 \mathrm{E} 6 \\
(0.75) \\
\end{array}$ & $\begin{array}{c}3.72 \mathrm{E} 6 \\
(0.83) \\
\end{array}$ & $\begin{array}{l}5.15 \mathrm{E} 7 \\
(1.00) \\
\end{array}$ & $\begin{array}{l}1.18 \mathrm{E} 5 \\
(0.64) \\
\end{array}$ \\
\hline $\begin{array}{l}\text { Particle from low-Cs/Ce tail } \\
\text { (511-SP18) }\end{array}$ & $\begin{array}{l}1.22 \mathrm{E} 7 \\
(0.86) \\
\end{array}$ & $\begin{array}{c}0.00 \mathrm{E} 0 \\
(0.00) \\
\end{array}$ & $\begin{array}{l}2.02 \mathrm{E} 5 \\
(0.61) \\
\end{array}$ & $\begin{array}{l}4.50 \mathrm{E} 6 \\
(0.78) \\
\end{array}$ & $\begin{array}{c}3.93 \mathrm{E} 6 \\
(0.88) \\
\end{array}$ & $\begin{array}{l}5.13 \mathrm{E} 7 \\
(0.99) \\
\end{array}$ & $\begin{array}{l}1.24 \mathrm{E} 5 \\
(0.68) \\
\end{array}$ \\
\hline $\begin{array}{l}\text { Particle from low-Cs/Ce tail } \\
\text { (511-SP19) }\end{array}$ & $\begin{array}{l}1.41 \mathrm{E} 7 \\
(1.00) \\
\end{array}$ & $\begin{array}{l}0.00 \mathrm{E} 0 \\
(0.00)\end{array}$ & $\begin{array}{l}2.30 \mathrm{E} 5 \\
(0.70) \\
\end{array}$ & $\begin{array}{l}5.24 \mathrm{E} 6 \\
(0.91) \\
\end{array}$ & $\begin{array}{l}4.55 \mathrm{E} 6 \\
(1.02) \\
\end{array}$ & $\begin{array}{l}5.96 \mathrm{E} 7 \\
(1.15)\end{array}$ & $\begin{array}{r}1.41 \mathrm{E} 5 \\
(0.76) \\
\end{array}$ \\
\hline $\begin{array}{l}\text { Particle from low-Cs/Ce tail } \\
(511-\mathrm{SP} 20)\end{array}$ & $\begin{array}{l}1.43 \mathrm{E} 7 \\
(1.01)\end{array}$ & $\begin{array}{l}0.00 \mathrm{E} 0 \\
(0.00)\end{array}$ & $\begin{array}{r}2.27 \mathrm{E} 5 \\
(0.69)\end{array}$ & $\begin{array}{l}4.55 \mathrm{E} 6 \\
(0.79)\end{array}$ & $\begin{array}{l}4.11 \mathrm{E} 6 \\
(0.92)\end{array}$ & $\begin{array}{l}5.88 \mathrm{E} 7 \\
(1.14)\end{array}$ & $\begin{array}{l}1.28 \mathrm{E} 5 \\
(0.70)\end{array}$ \\
\hline $\begin{array}{l}\text { Particle from low-Cs/Ce tail } \\
\text { (511-SP21) }\end{array}$ & $\begin{array}{l}1.33 \mathrm{E} 7 \\
(0.94)\end{array}$ & $\begin{array}{c}0.00 \mathrm{E} 0 \\
(0.00)\end{array}$ & $\begin{array}{c}2.17 \mathrm{E} 5 \\
(0.66)\end{array}$ & $\begin{array}{l}5.15 \mathrm{E} 6 \\
(0.89)\end{array}$ & $\begin{array}{c}4.28 \mathrm{E} 6 \\
(0.96)\end{array}$ & $\begin{array}{l}5.78 \mathrm{E} 7 \\
(1.12)\end{array}$ & $\begin{array}{l}1.39 \mathrm{E} 5 \\
(0.76)\end{array}$ \\
\hline $\begin{array}{l}\text { Particle from low-Cs/Ce tail } \\
\text { (511-SP22) }\end{array}$ & $\begin{array}{l}1.30 \mathrm{E} 7 \\
(0.92)\end{array}$ & $\begin{array}{c}0.00 \mathrm{E} 0 \\
(0.00)\end{array}$ & $\begin{array}{c}2.10 \mathrm{E} 5 \\
(0.64)\end{array}$ & $\begin{array}{c}5.06 \mathrm{E} 6 \\
(0.88)\end{array}$ & $\begin{array}{c}4.23 \mathrm{E} 6 \\
(0.95)\end{array}$ & $\begin{array}{l}5.62 \mathrm{E} 7 \\
(1.09)\end{array}$ & $\begin{array}{l}1.37 \mathrm{E} 5 \\
(0.74) \\
\end{array}$ \\
\hline $\begin{array}{l}\text { Particle from low-Cs/Ce tail } \\
\text { (511-SP23) }\end{array}$ & $\begin{array}{l}1.34 \mathrm{E} 7 \\
(0.95)\end{array}$ & $\begin{array}{c}0.00 \mathrm{E} 0 \\
(0.00)\end{array}$ & $\begin{array}{c}2.26 \mathrm{E} 5 \\
(0.68)\end{array}$ & $\begin{array}{c}5.37 \mathrm{E} 6 \\
(0.93)\end{array}$ & $\begin{array}{l}4.42 \mathrm{E} 6 \\
(0.99)\end{array}$ & $\begin{array}{l}5.48 \mathrm{E} 7 \\
(1.06)\end{array}$ & $\begin{array}{l}1.46 \mathrm{E} 5 \\
(0.79) \\
\end{array}$ \\
\hline $\begin{array}{l}\text { Particle from low-Cs/Ce tail } \\
\text { (511-SP24) }\end{array}$ & $\begin{array}{l}1.45 \mathrm{E} 7 \\
(1.03)\end{array}$ & $\begin{array}{c}0.00 \mathrm{E} 0 \\
(0.00)\end{array}$ & $\begin{array}{l}2.46 \mathrm{E} 5 \\
(0.74)\end{array}$ & $\begin{array}{l}5.58 \mathrm{E} 6 \\
(0.97)\end{array}$ & $\begin{array}{l}4.65 \mathrm{E} 6 \\
(1.04)\end{array}$ & $\begin{array}{l}6.08 \mathrm{E} 7 \\
(1.18)\end{array}$ & $\begin{array}{l}1.54 \mathrm{E} 5 \\
(0.84)\end{array}$ \\
\hline
\end{tabular}

Values in parentheses are the measured/calculated ratios.

Shaded particles were imaged with x-ray. 


\section{MICROSTRUCTURAL ANALYSIS OF INDIVIDUAL PARTICLES}

\section{Analysis of particles that released cesium during safety testing}

As mentioned in the IMGA discussion, Low-Cs/Ce Particle 3 (511-SP02) exhibited a measurably-low inventory for all the radioisotopes detected with IMGA. X-ray tomographs of this particle (Figure 8), show that it was missing most of its kernel material. This particle is an example of a fluidization defect sometimes called a $\mathrm{SiC}$ soot inclusion. The abnormal $\mathrm{SiC}$ layer structure was caused by the particle getting temporarily trapped somewhere in the coater, such that it spent a significant fraction of the 140-minute $\mathrm{SiC}$ deposition period not circulating through the primary coating region. The x-ray tomographs in Figure 8 show a thin dense SiC layer at the IPyC interface, another thin dense layer at the $\mathrm{OPyC}$ interface, and an abnormal layer sandwiched between. This structure was presumably formed when the particle was temporarily ejected from the fluidized particle bed and stuck in the carbon soot on the walls of the upper coater section. The particle then apparently returned to the fluidized bed near the end of the $\mathrm{SiC}$ deposition period and received a normal OPyC coating. Irradiation test data [Collins 2015] and post-irradiation inspection of the Capsule 5 graphite holder [Harp 2013] indicate that this as-fabricated defect survived the three-year AGR-1 irradiation test without releasing significant quantities of cesium or krypton, only experiencing a through-layer $\mathrm{SiC}$ failure during the $1700^{\circ} \mathrm{C}$ safety testing. Because there was no large release of krypton during the safety test, it is reasonable to assume that the OPyC crack, visible in Figure 8b, did not occur until the deconsolidation or pre-burn acid leaching; at which time acid apparently penetrated to the kernel and removed material.
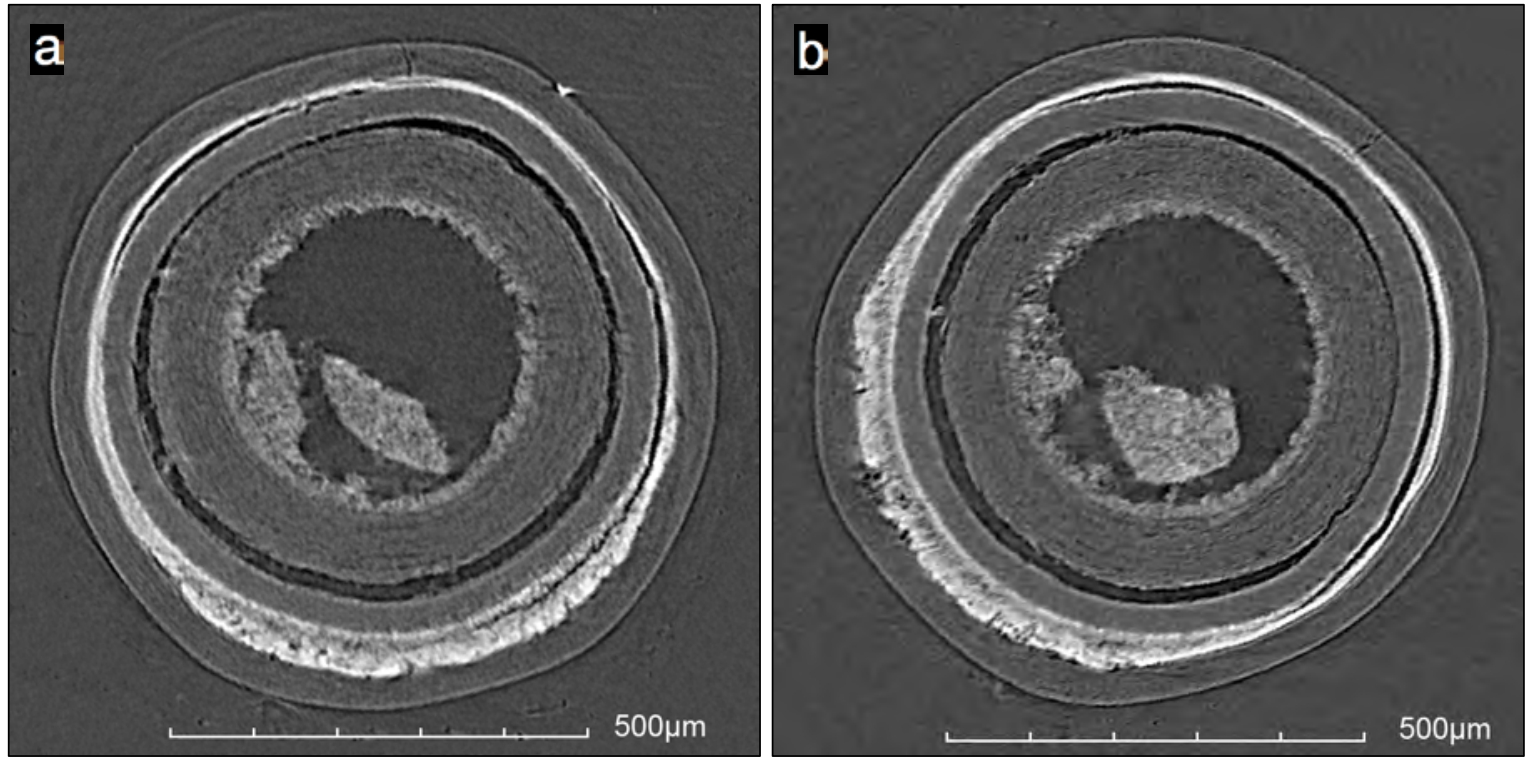

Figure 8. Low Cs/Ce Particle 3 (511-SP02): oblique orthogonal x-ray tomographs showing a gross SiC inclusion (pre-irradiation defect), and only residual kernel material remaining after pre-burn leaching.

The other two particles that released cesium during safety testing exhibited the typical degraded $\mathrm{SiC}$ and general particle microstructure that has been identified in other particles with $\mathrm{SiC}$ failure during 1700 and $1800^{\circ} \mathrm{C}$ safety testing [Hunn et al. 2014-2]; namely, localized $\mathrm{SiC}$ degradation by palladium where radiation-induced shrinking of the buffer has led to IPyC cracking and exposure of the inside surface of the SiC. Low-Cs/Ce Particle 1 showed extensive SiC degradation where it was exposed by a fracture through the buffer and IPyC layer, which remain bonded to each other where the fracture occurred (Figure 9). Kernel protrusion into the fracture gap resulted in a significant amount of kernel material coming in contact with the SiC. Metallic fission products can be seen within the degraded $\mathrm{SiC}$ and piled up in the OPyC outside the $\mathrm{SiC}$ penetration point (Figure 10). This pileup in the OPyC has not been previously observed, and is discussed further below in conjunction with the electron microscopy results. 

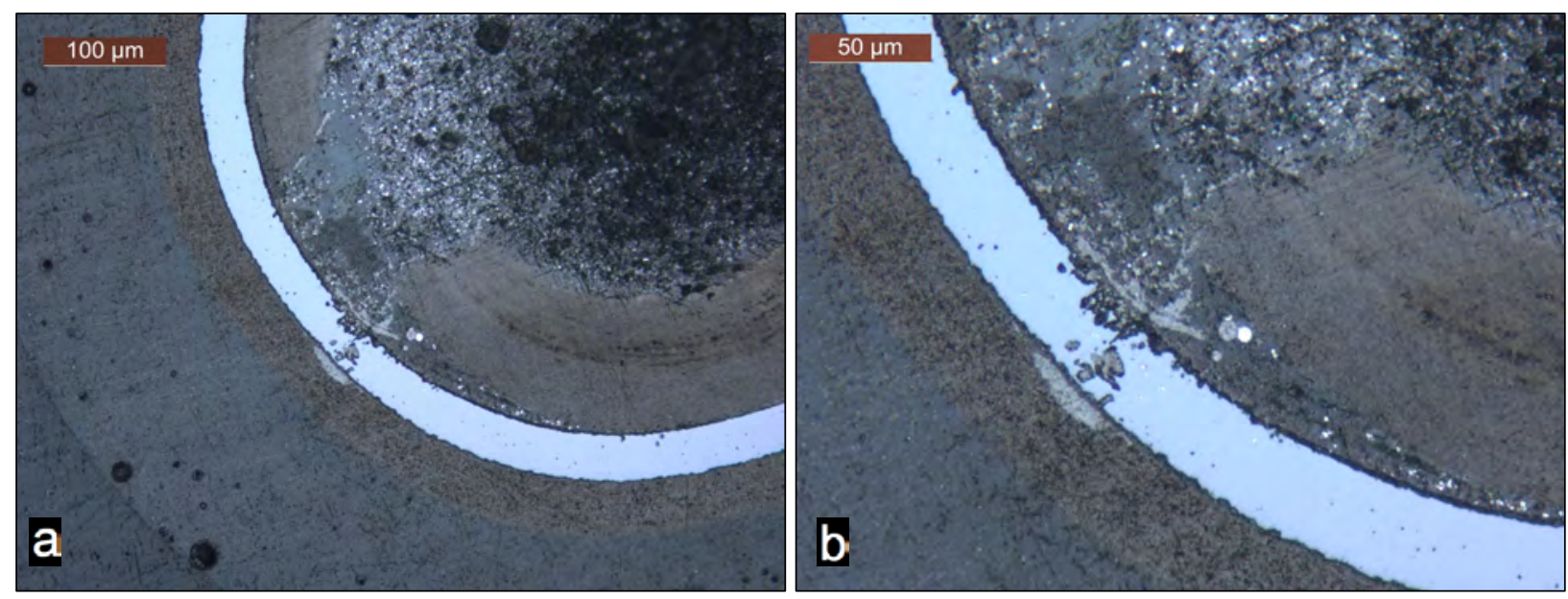

Figure 9. Low-Cs/Ce Particle 1 (511-SP03): optical micrographs showing buffer and IPyC fracture, $\mathrm{IPyC} / \mathrm{SiC}$ delamination, kernel protrusion reaching the $\mathrm{SiC}$, and localized $\mathrm{SiC}$ degradation by palladium.

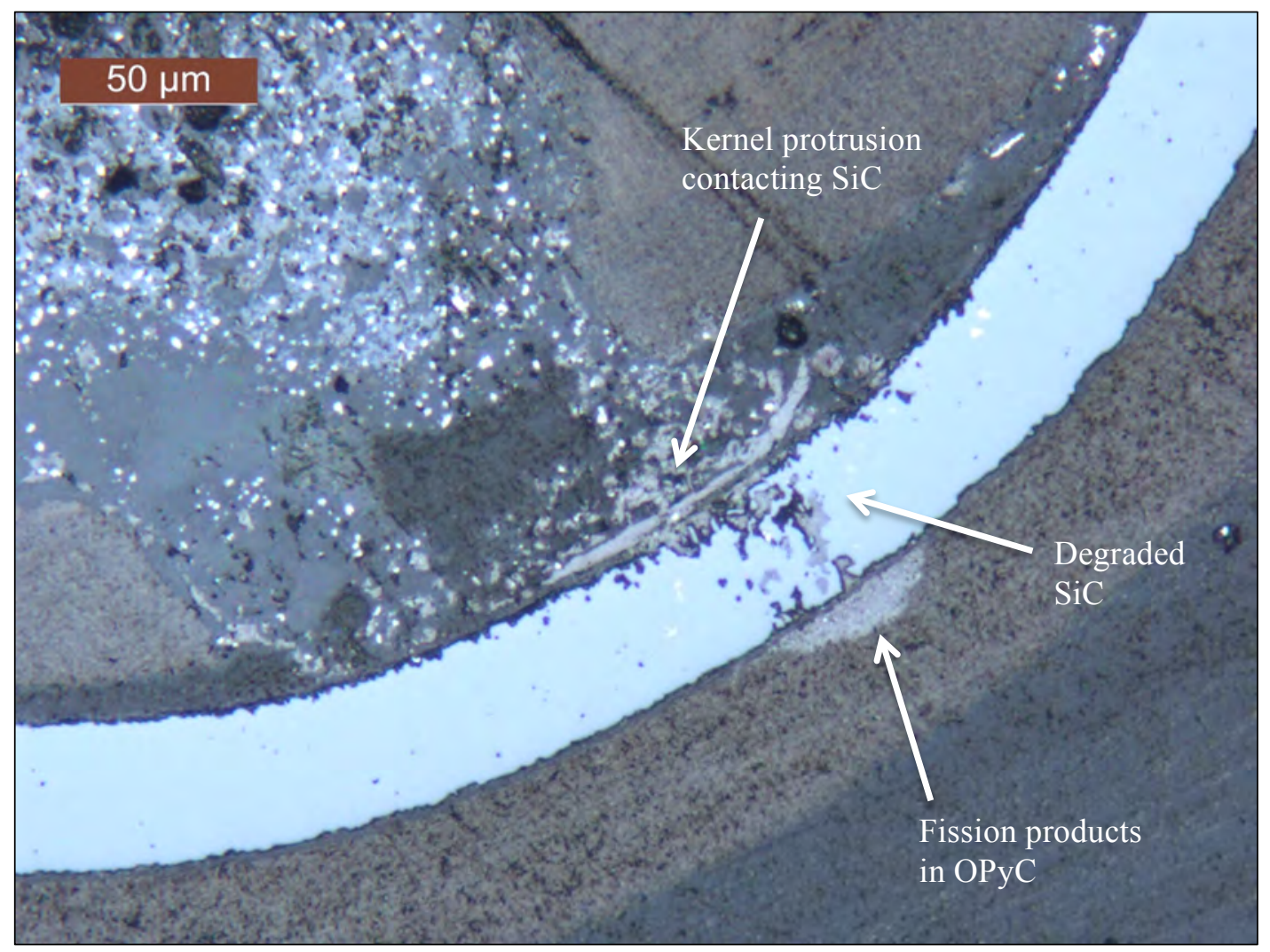

Figure 10. Low-Cs/Ce Particle 1 (511-SP03): optical micrograph showing same region as Figure 9 after additional polishing; a significant concentration of fission products can be seen in the OPyC layer, adjacent to the degraded $\mathrm{SiC}$.

Images of select areas of interest in Low-Cs/Ce Particle 1 are presented in Figure 11 using SEM secondary-electron imaging (SEI) and backscattered-election composition (BEC) image pairs to highlight the anomalies. The contrast observed in BEC imaging is dependent on the atomic number (Z), with low-Z regions appearing dark and high- $Z$ regions appearing bright. The BEC imaging is ideal for identifying high-Z fission products clustered in the low-Z TRISO layers. The SEI imaging is more topographically sensitive and allows for differentiation of surface features such as hot cell contamination and polishing artifacts from actual embedded fission products. Three distinct features were observed involving the 
distribution of high-Z elements within the particle. Significant redistribution or protrusion of the kernel material into open areas formed by buffer and IPyC fracture is apparent in Figure 11a-c and Figure 11e, where high-Z kernel material can be seen to have migrated all the way to the SiC layer through the failed buffer and IPyC. A second feature of interest is the layer of high-Z material lining the IPyC and SiC layers in the region where the IPyC delaminated from the SiC layer, shown in Figure 11b and Figure 11d. The last region of interest is the $\mathrm{SiC}$ degradation region. The $\mathrm{SiC}$ degradation was adjacent to the largest IPyC failure and most-prominent kernel protrusion; BEC imaging shows a large buildup of fission product features in and around the degraded $\mathrm{SiC}$.
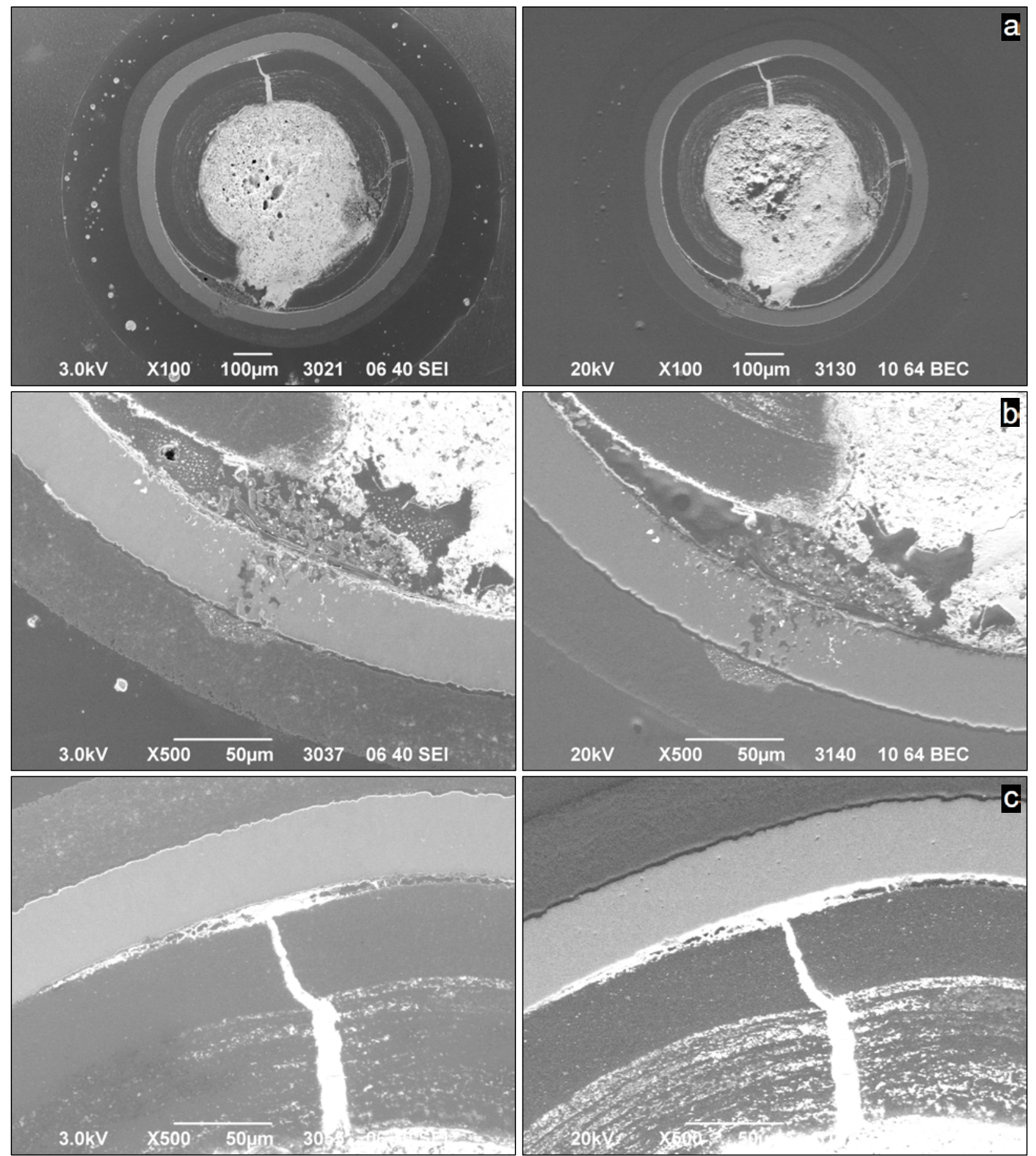

Figure 11. SEI/BEC-paired images of Low-Cs/Ce Particle 1 (511-SP03): a) particle overview, b) kernel protrusion adjacent to $\mathrm{SiC}$ degradation, and c) fission products filling IPyC crack. 

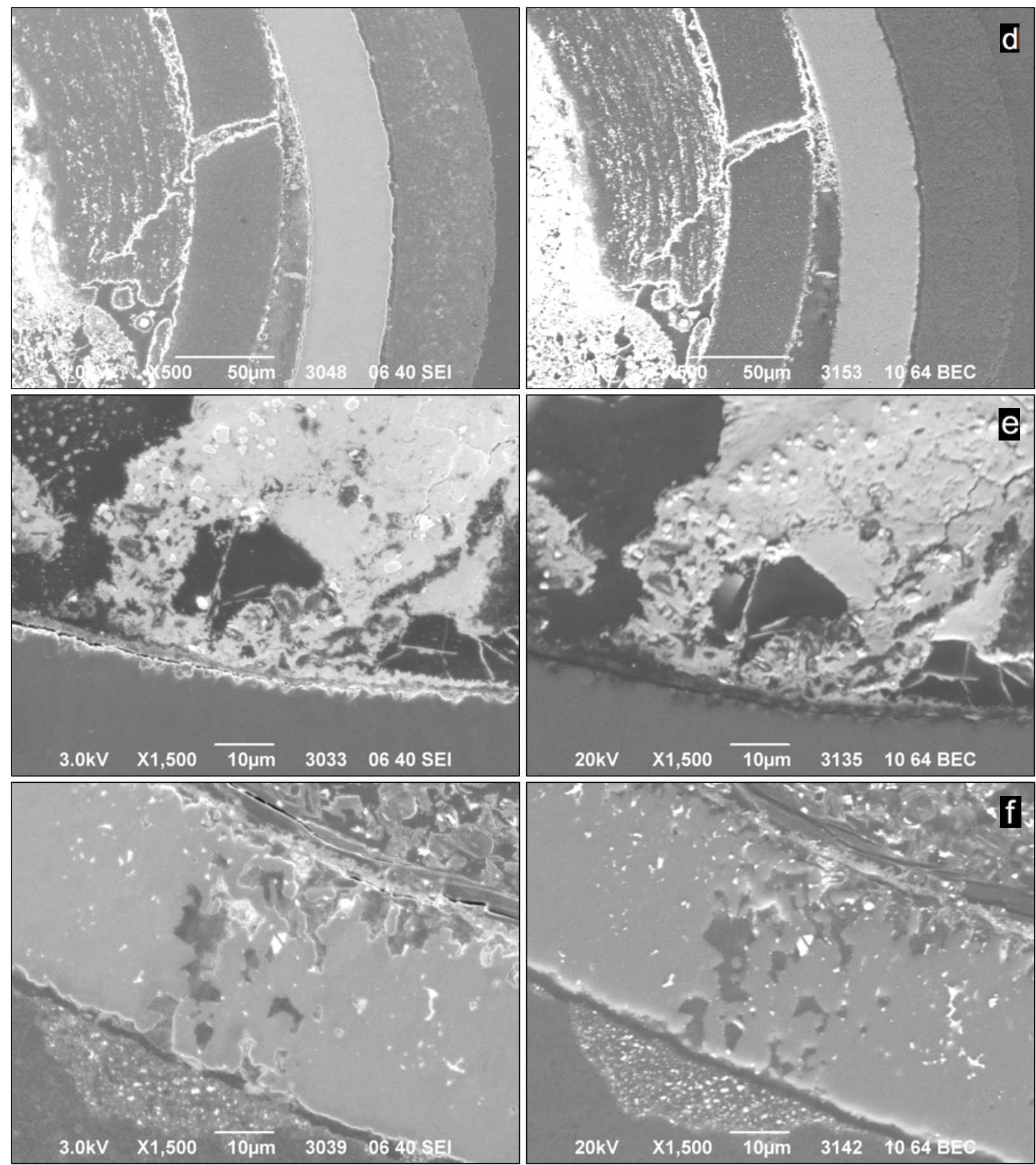

Figure 11 (continued) SEI/BEC-paired images of Low-Cs/Ce Particle 1 (511-SP03): d) IPyC crack and $\mathrm{IPyC} / \mathrm{SiC}$ delamination lined with fission products, e) kernel in contact with $\mathrm{SiC}$, and $\mathrm{f}$ ) $\mathrm{SiC}$ degradation with fission products in OPyC.

Analysis with EDS was employed on all features of interest identified in Figure 11. Elemental maps of the protruded kernel are shown in Figure 12; both features are primarily mixtures of uranium and molybdenum with included oxygen and carbon. (Uranium is not shown in Figure 12a, as its intensity limits the ability to visualize the distribution of ruthenium and zirconia.) The large segregation of a Mo-rich phase has not been noted in previous observations of kernel protrusions, which typically have elemental content consistent with the bulk of the kernel. The EDS map of Figure 12a indicates secondary $\mathrm{Zr}$-rich phases in the kernel, as well as a buildup of ruthenium near and within the $\mathrm{SiC}$ degradation. 
Analysis of randomly selected particles from Compact 5-1-1 showed finely-dispersed secondary Mo-rich and Zr-rich phases distributed throughout the kernel. The observation of a segregated U-Mo phase in Low-Cs/Ce Particle 1 indicates significant kernel chemistry changes occurred.
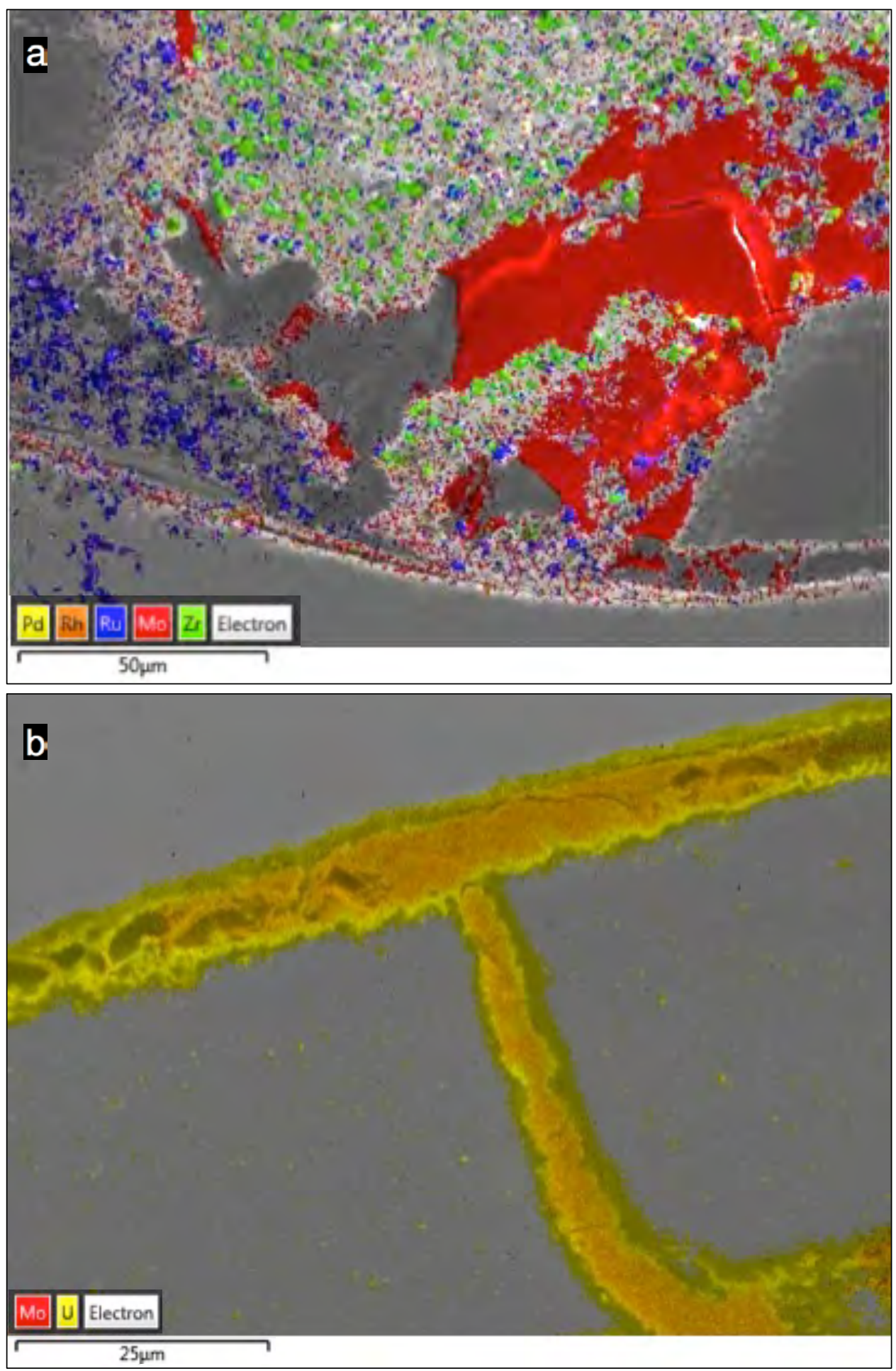

Figure 12. Low-Cs/Ce Particle 1 (511-SP03): EDS elemental-intensity maps overlaid on SEI reference images of a) the large kernel protrusion near the degraded $\mathrm{SiC}$ region (Figure $11 \mathrm{~b}$ and e), and $\mathrm{b}$ ) fission products in the IPyC crack shown in Figure 11c. U is not shown in (a) as its intensity limits observable details in Mo, $\mathrm{Ru}$, and $\mathrm{Zr}$ distributions. 
Figure 13 shows an EDS map of the high-Z material lining the IPyC and SiC layers in the region where the IPyC is delaminated from the $\mathrm{SiC}$ (Figure 11d). The map confirms the layer is uranium. No significant molybdenum or contribution from other elements was noted. The reason for the different elemental distribution in the two IPyC crack regions shown in Figure 12b and Figure 13 is not explicitly known. Notable differences included the fact that the Mo-rich material in Figure $12 \mathrm{~b}$ is in contact with the kernel while the U-rich layer in Figure 13 does not have a directly observable pathway to the kernel.

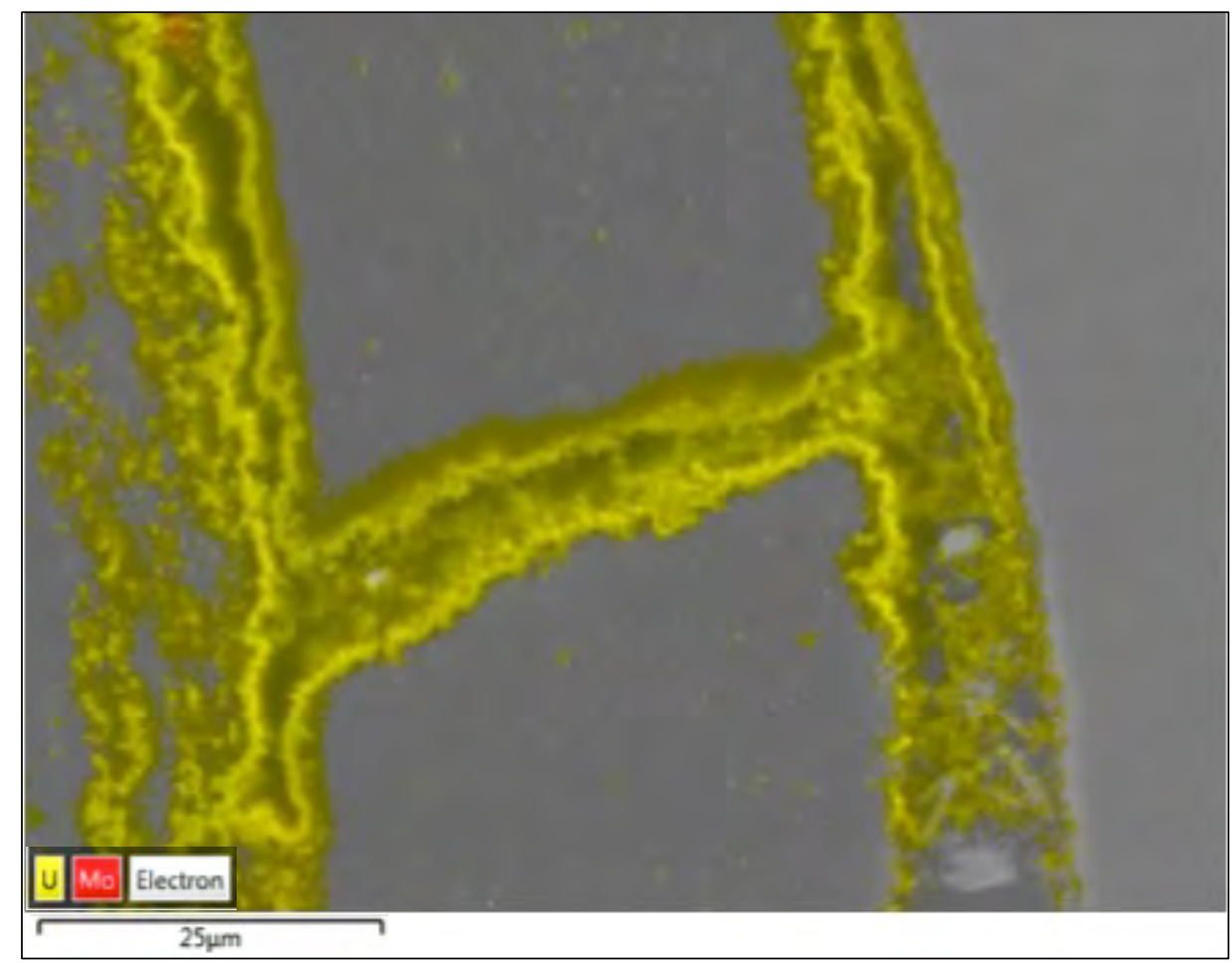

Figure 13. Low-Cs/Ce Particle 1 (511-SP03): EDS map of the IPyC crack with high-Z lining shown in Figure 11d.

The $\mathrm{SiC}$ degradation in Low-Cs/Ce Particle 1 presents a unique case, as the presence of fission products in the OPyC layer surrounding a region of $\mathrm{SiC}$ degradation (Figure 10 and Figure 11f) have not been previously observed. The primary features of the $\mathrm{SiC}$ degradation remained consistent with previouslyobserved degraded $\mathrm{SiC}$; namely, high-Z fission product features surround the $\mathrm{SiC}$ degradation and appear to advance in front of $\mathrm{C}$-rich phases in the $\mathrm{SiC}$ layer, where silicon has presumably been removed by formation and out-diffusion of silicide [Hunn et al. 2014-1; Hunn et al. 2014-2]. Figure 14 shows a set of single-element EDS maps of the higher-concentration elements found in the degraded area. Collocated with these predominant elements were measurable amounts of rhodium, zirconium, molybdenum, and palladium. Lighter-areas visible in the $\mathrm{SiC}$ (without color assigned during EDS mapping) were also identified as fission product features by longer-count EDS point analysis. In the SEI and BEC images in Figure 11f, darker areas in the $\mathrm{SiC}$ correspond to higher-intensity regions in the Figure 14 carbon map and show greatly-reduced intensity in the silicon map, confirming that these regions are C-rich, Si-depleted zones. Ruthenium and uranium were the dominant fission products remaining in the degraded area with U-rich features at the $\mathrm{IPyC} / \mathrm{SiC}$ interface and $\mathrm{Ru}$-rich features in the $\mathrm{SiC}$ and OPyC. The fission products in the $\mathrm{OPyC}$ surrounding the $\mathrm{SiC}$ degradation zone are suggested to be silicides of ruthenium, uranium, and rhodium. Oxygen and carbon were also identified in this area; however, accurate confirmation of the contributions from these elements is difficult due to matrix effects and low- $Z$ sensitivity challenges. The relative composition of the features in the $\mathrm{OPyC}$ layer is estimated to be $28.5 \% \mathrm{Ru}, 12.1 \% \mathrm{U}, 6.9 \% \mathrm{Rh}$, and $52.5 \% \mathrm{Si}$ (assuming insignificant oxygen or carbon content). The features in the $\mathrm{SiC}$ degradation zone were similar in composition, but also contained measurable palladium. Within the SiC layer, the presence of silicon, carbon, or oxygen could not be directly determined due to matrix effects and poor 
low-Z sensitivity. Assuming a similar composition of silicides, the relative concentration of the constituent fission product elements would be $21.5 \% \mathrm{Ru}, 17.1 \% \mathrm{U}, 6.2 \% \mathrm{Rh}$, and $2.7 \% \mathrm{Pd}$; as such, the composition is very similar to the features in the OPyC layer, with the exception of the presence of palladium and an increase in uranium content at the expense of ruthenium. The majority of features at the $\mathrm{IPyC} / \mathrm{SiC}$ interface are U-rich. Ruthenium, molybdenum, and zirconium were also observed with uranium in some interface features. A few other features at the IPyC/SiC interface had similar composition to the features observed in the $\mathrm{SiC}$ degradation region. The reason for the higher concentration of elements other than the palladium and uranium usually observed in degraded $\mathrm{SiC}$ is not explicitly known, but appears to be related to the greater out-diffusion of fission products into the OPyC.
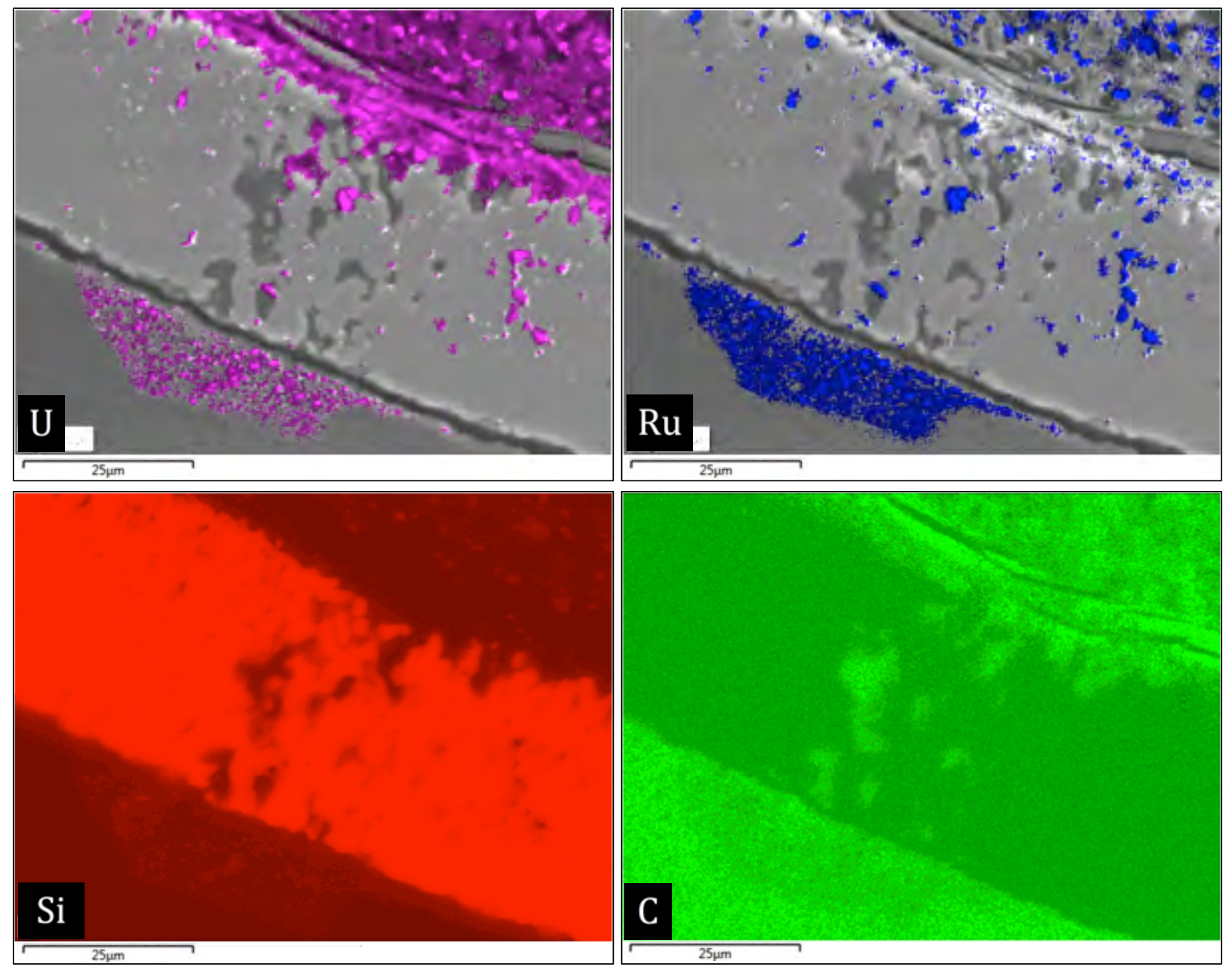

Figure 14. Low-Cs/Ce Particle 1 (511-SP03): EDS maps of SiC degradation area (Figure 11d) showing distributions of the higher-concentration fission products.

Low-Cs/Ce Particle 2 also experienced buffer fracture due to the radiation-induced shrinkage in this lowdensity carbon layer. X-ray tomographs in Figure 15 show kernel protrusion into the buffer fracture, but the $\mathrm{SiC}$ degradation is not related to this kernel protrusion. A low-density penetration of the $\mathrm{SiC}$ can be seen in a region where partial delamination of the buffer from the IPyC led to IPyC cracking and SiC failure; this is more evident in the optically-imaged cross sections in Figure 16. The buffer tore away from the IPyC on either side of a buffer fracture, and this buffer/IPyC delamination appears to terminate on one side at a crack through the IPyC. Fission product pileup and eventual SiC degradation occurred at the tip of the IPyC crack, where the SiC interface was exposed. The localized nature of this $\mathrm{SiC}$ degradation is illustrated in Figure 16 by the fact that additional polishing, which probably removed $10-20 \mu \mathrm{m}$ from the polished surface, resulted in polishing almost all the way through the degraded zone. 

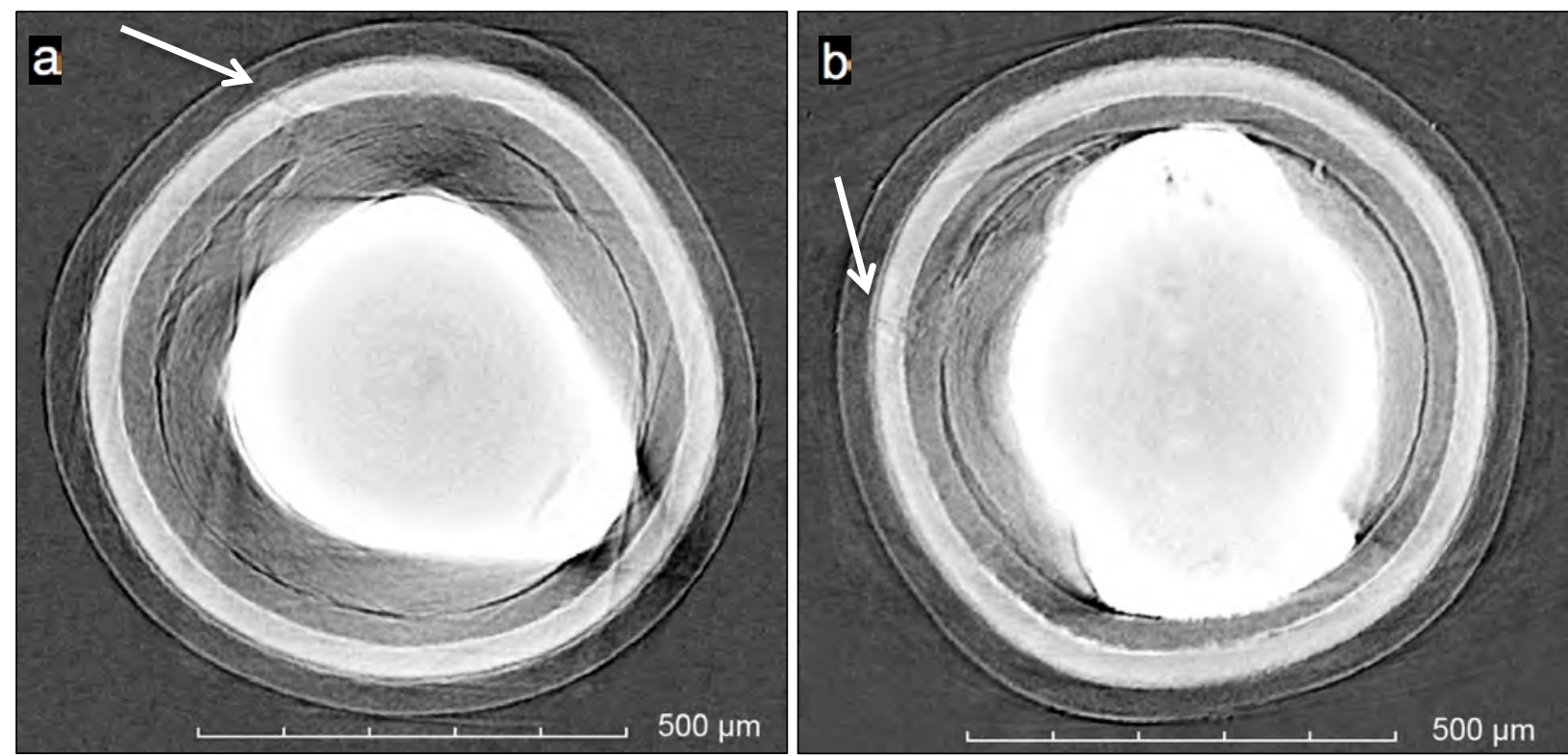

Figure 15. Low-Cs/Ce Particle 2 (511-SP04): oblique orthogonal x-ray tomographs showing fractured buffer, kernel protrusion, partial buffer/IPyC delamination, and $\mathrm{SiC}$ degradation (identified by arrows).
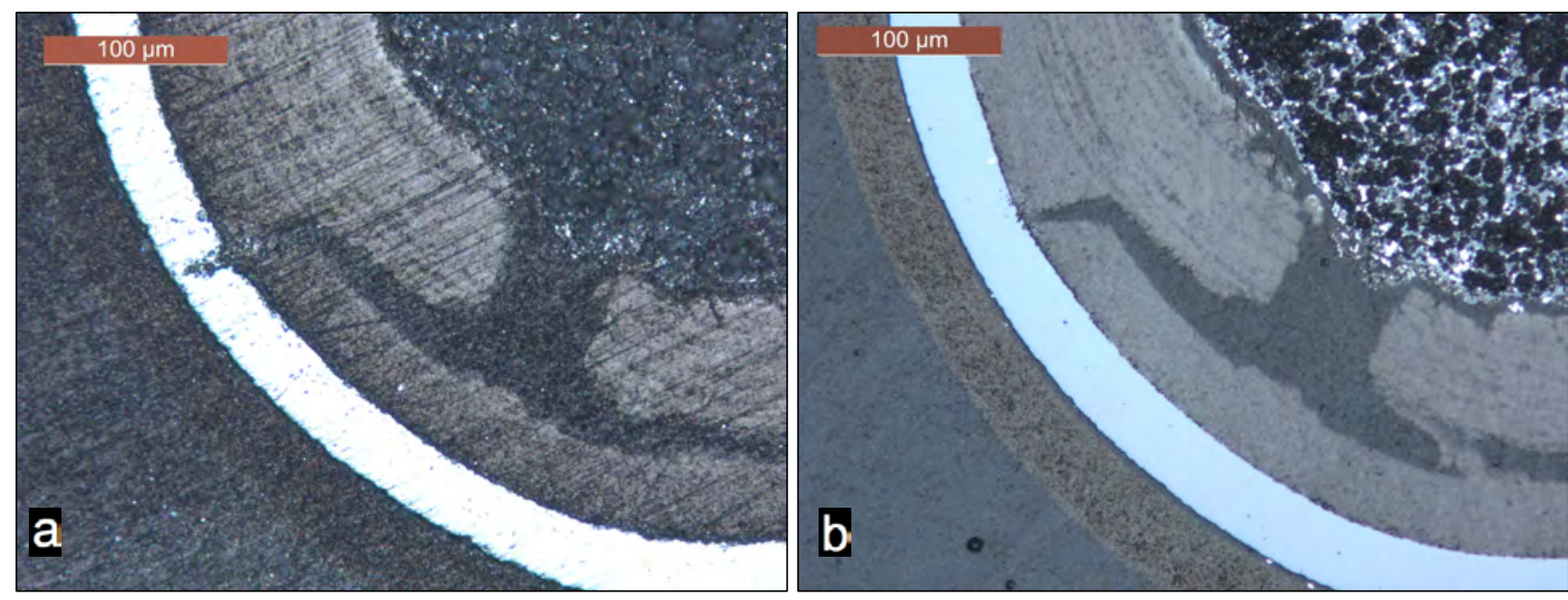

Figure 16. Low-Cs/Ce Particle 2 (511-SP04): a) optical micrograph taken during grinding showing buffer fracture, incomplete buffer/IPyC delamination, IPyC crack at the edge of buffer/IPyC delamination, and localized $\mathrm{SiC}$ degradation; and b) optical micrograph of fully-polished plane showing same region, but just beyond point where the $\mathrm{SiC}$ degradation penetrated the layer.

Figure 17 shows SEI/BEC-image pairs of the IPyC crack and SiC degradation area that remained after final polishing of Low-Cs/Ce Particle 2. The projection of the $\mathrm{SiC}$ degradation area observed in this cross section does not traverse the entire $\mathrm{SiC}$ layer thickness; however, it does provide indication of a $\mathrm{SiC}$ degradation mechanism consistent with what has been observed in most AGR-1 particles with failed SiC. Large fission product features are present in the $\mathrm{SiC}$ layer surrounding $\mathrm{C}$-rich regions, similar to features previously observed in other particles with degraded SiC [Hunn et al. 2014-1, Hunn et al. 2014-2]. The area around the IPyC crack is depleted of the segregated fission product features seen elsewhere in the $\mathrm{IPyC}$, indicating their higher mobility near the crack, which appears to facilitate the transport of fission product species to the degradation site and the transport of products of the degradation reaction away from the site. Figure 17a also indicates a thinning of the $\mathrm{SiC}$ layer in the immediate vicinity surrounding the $\mathrm{SiC}$ degradation area, in conjunction with an absence of the normally-interlaced $\mathrm{IPyC} / \mathrm{SiC}$ interface. 
There also appears to be a variation in the IPyC structure adjacent to the degraded $\mathrm{SiC}$ region that has been observed in other particles with noted SiC degradation areas [Hunn et al. 2014].
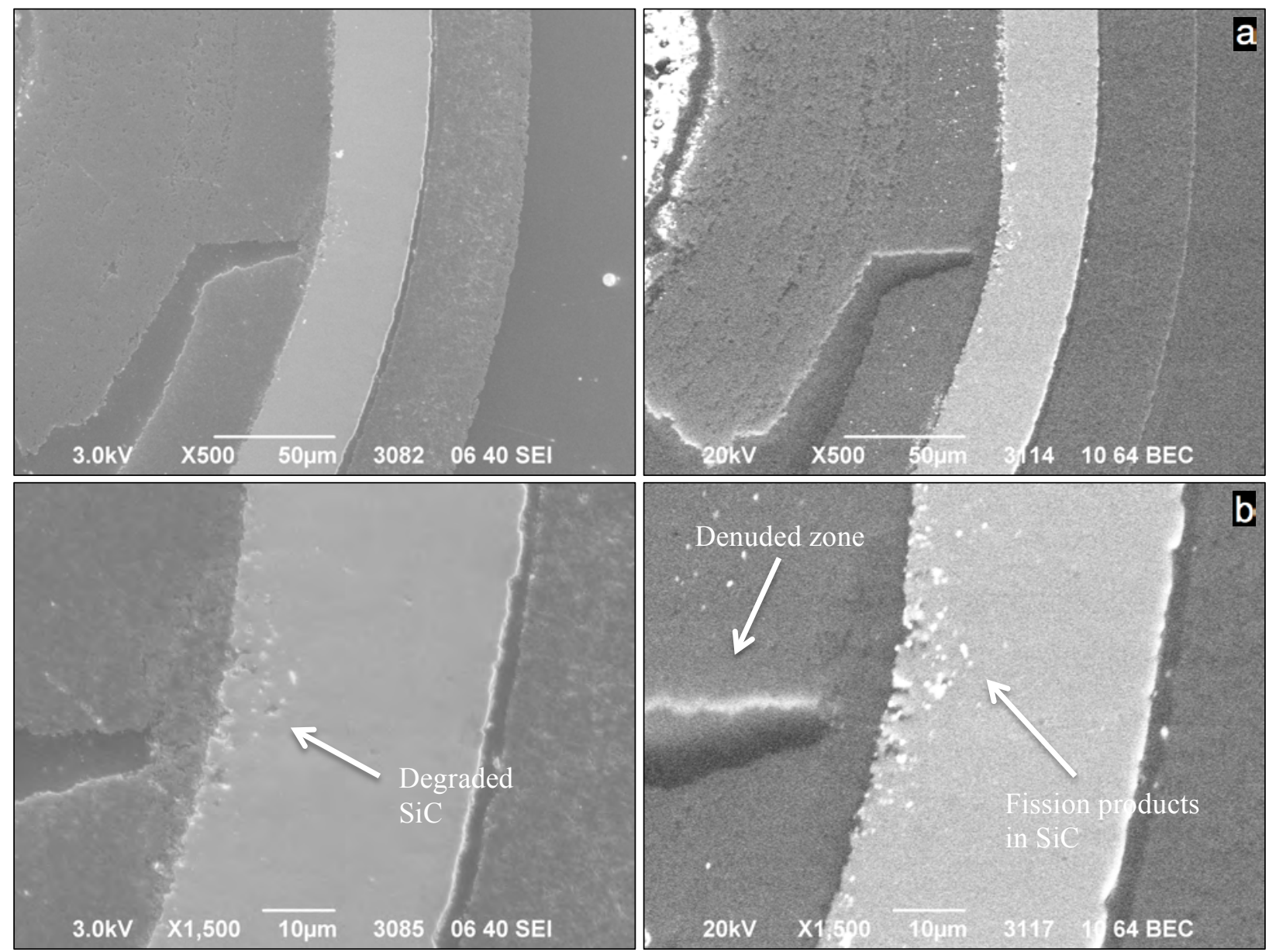

Figure 17. SEI/BEC-paired images of Low-Cs/Ce Particle 2 (511-SP04): a) IPyC crack and SiC degradation area overview and $\mathrm{b}$ ) closeup of the $\mathrm{SiC}$ degradation area.

Elemental analysis of the $\mathrm{SiC}$ degradation area in Low $\mathrm{Cs} / \mathrm{Ce}$ Particle 2 predominantly indicated the presence of palladium, uranium, and rhodium in the fission product clusters in the immediate vicinity of the $\mathrm{SiC}$ degradation site. Carbon and silicon were also identified in all features, but due to matrix contributions, accurate insight into their content within the fission product clusters cannot be determined. However based on the analysis of larger features, which limit matrix contribution, it is suggested the features were silicides based on their Si-rich nature. Oxygen was also identified in a majority of the features, but, as already mentioned, accurate analysis of oxygen is problematic. Figure 18 shows an EDS mapping of the palladium, uranium, and rhodium, which were mostly-located in features less than $10 \mu \mathrm{m}$ from the IPyC/SiC interface. Neodymium and plutonium were also identified in select clusters in the $\mathrm{SiC}$ degradation area; however, direct confirmation of plutonium is limited due to peak overlap with uranium. The finer-scale fission product features deeper in the $\mathrm{SiC}$ layer were observed to be primarily palladium and uranium. Rhodium was not identified; however, it cannot be ruled out due to a minimum interaction volume limiting the sensitivity limits of the EDS system for these smaller features. At the IPyC/SiC interface away from the $\mathrm{SiC}$ degradation site, the fission product features were primarily palladium and uranium, or just uranium; although a few fission product clusters also showed zirconium and neodymium or a mixture of palladium, uranium, and rhodium. 


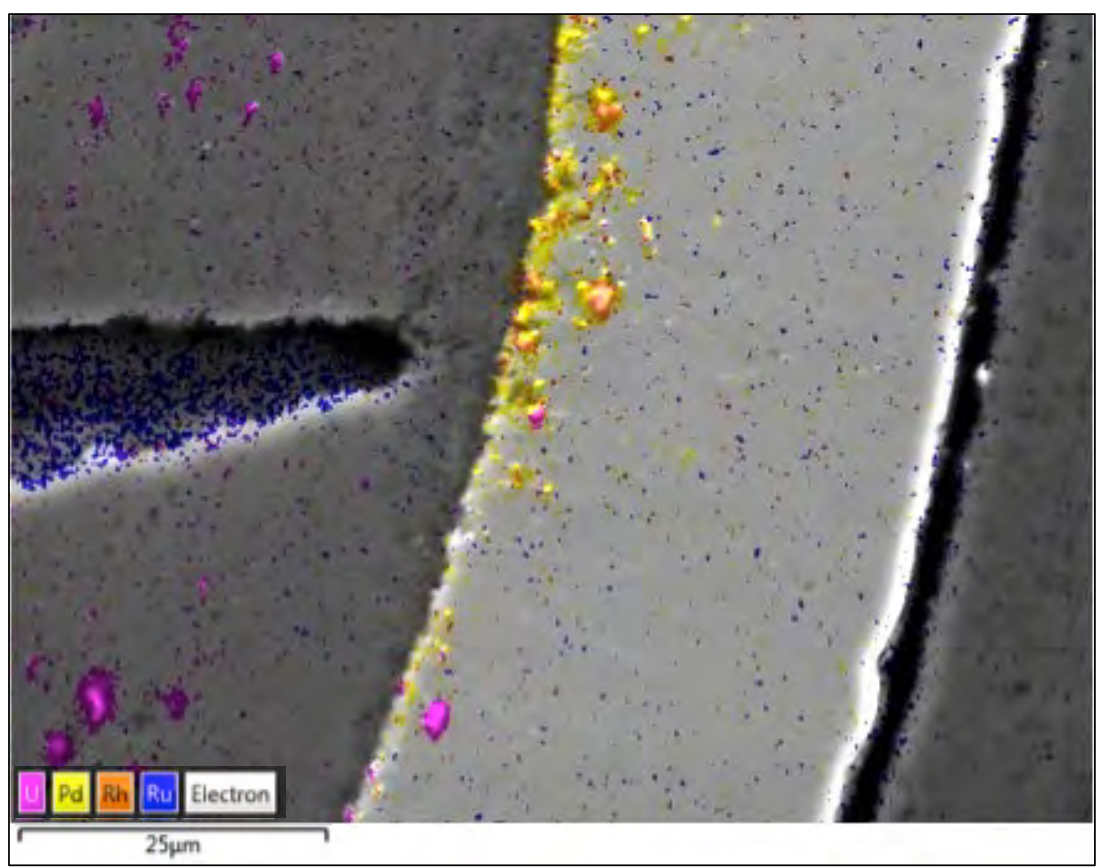

Figure 18. Low-Cs/Ce Particle 2 (511-SP04) EDS map of SiC degradation area, element intensity is color coded and overlaid on the SEI reference image. 


\section{Analysis of particles specially-selected from the low-end tail of the Cs/Ce distribution}

X-ray tomography was used to image three particles from the lower end of the Cs/Ce distribution (see Table 6 and Figure 6). All three particles exhibited similar, defect-free microstructures (Figure 19), where buffer densification resulted in clean delamination between the buffer and IPyC layers, with buffer layers remaining intact. No damage or degradation was evident in the outer three coating layers that would indicate these particles would experience below-average cesium retention, which leads to the conclusion that the below-average cesium inventory in these particles was most likely due to variations in initial fissile content or burnup, as opposed to cesium release.
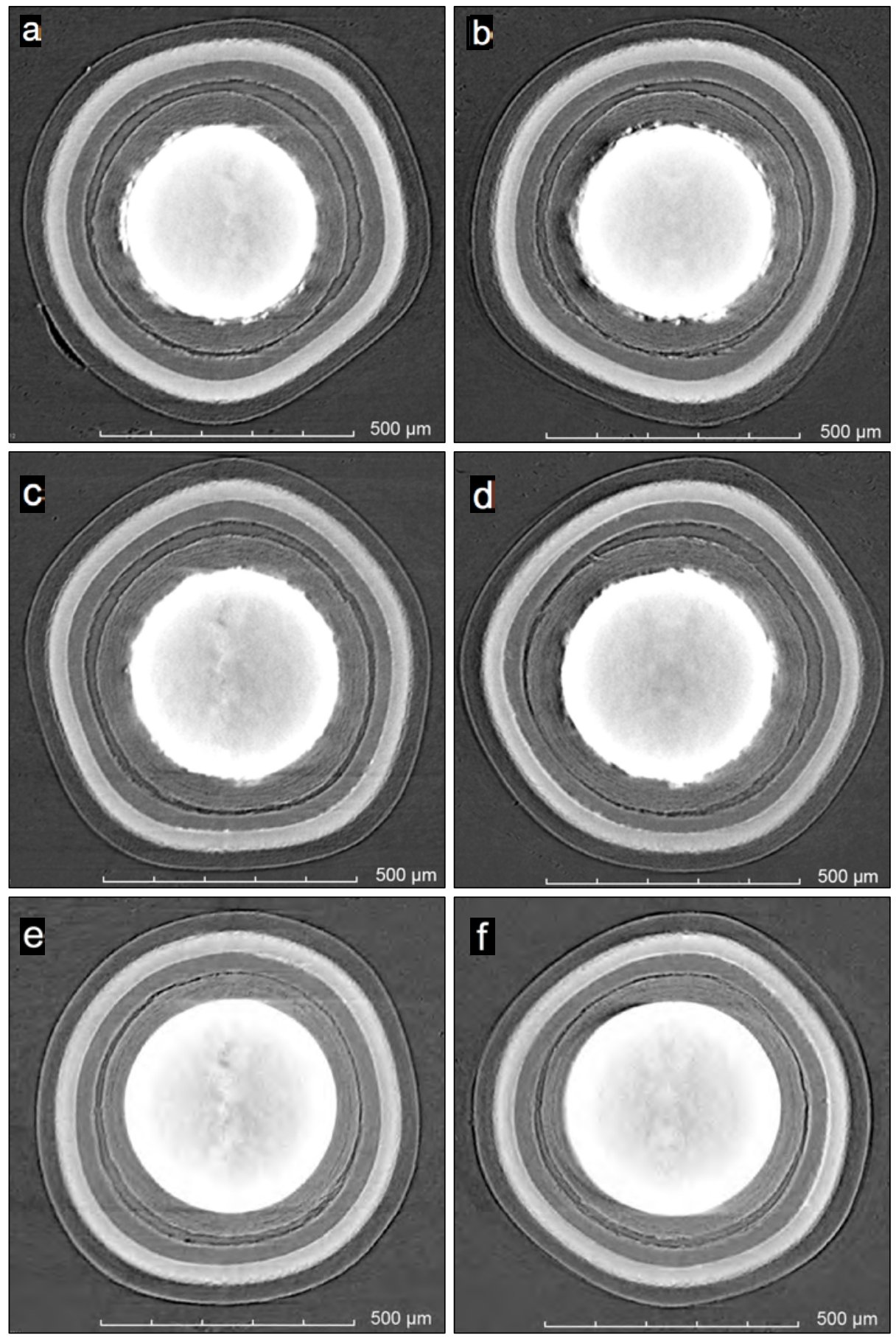

Figure 19. Orthogonal x-ray tomographs near midplane of Particle 511-SP17 (a and b), Particle 511-SP18 (c and d), and Particle 511-SP20 (e and f) showing typical buffer shrinkage and delamination from IPyC. 


\section{Analysis of randomly-selected particles}

Two of the particles randomly-selected for IMGA measurement were imaged with x-ray tomography (Figure 20). Particle 511-RS03 had an average radioisotopic inventory, including a ${ }^{110 \mathrm{~m}} \mathrm{Ag} \mathrm{M} / \mathrm{C}=0.99$; while Particle 511-RS05 had a similar average radioisotopic inventory, except for ${ }^{110 \mathrm{~m}} \mathrm{Ag}$, which was below a detection limit of $\mathrm{M} / \mathrm{C}<0.65$. Both particles exhibited defect-free microstructures similar to those in Figure 19, where buffer densification resulted in delamination between the buffer and IPyC layers, but no buffer fracture. Again, no damage or degradation was evident in the outer three coating layers other than a slight separation between the $\mathrm{SiC}$ and OPyC which has been observed in most of the AGR-1 particles, especially after safety testing. This $\mathrm{SiC} / \mathrm{OPyC}$ gap has been attributed to the shrinking matrix pulling the $\mathrm{OPyC}$ away from the $\mathrm{SiC}$ due to the stronger interface bond between the matrix and porous OPyC, compared to the OPyC and non-porous SiC [Hunn et al. 2013-2, page 27].
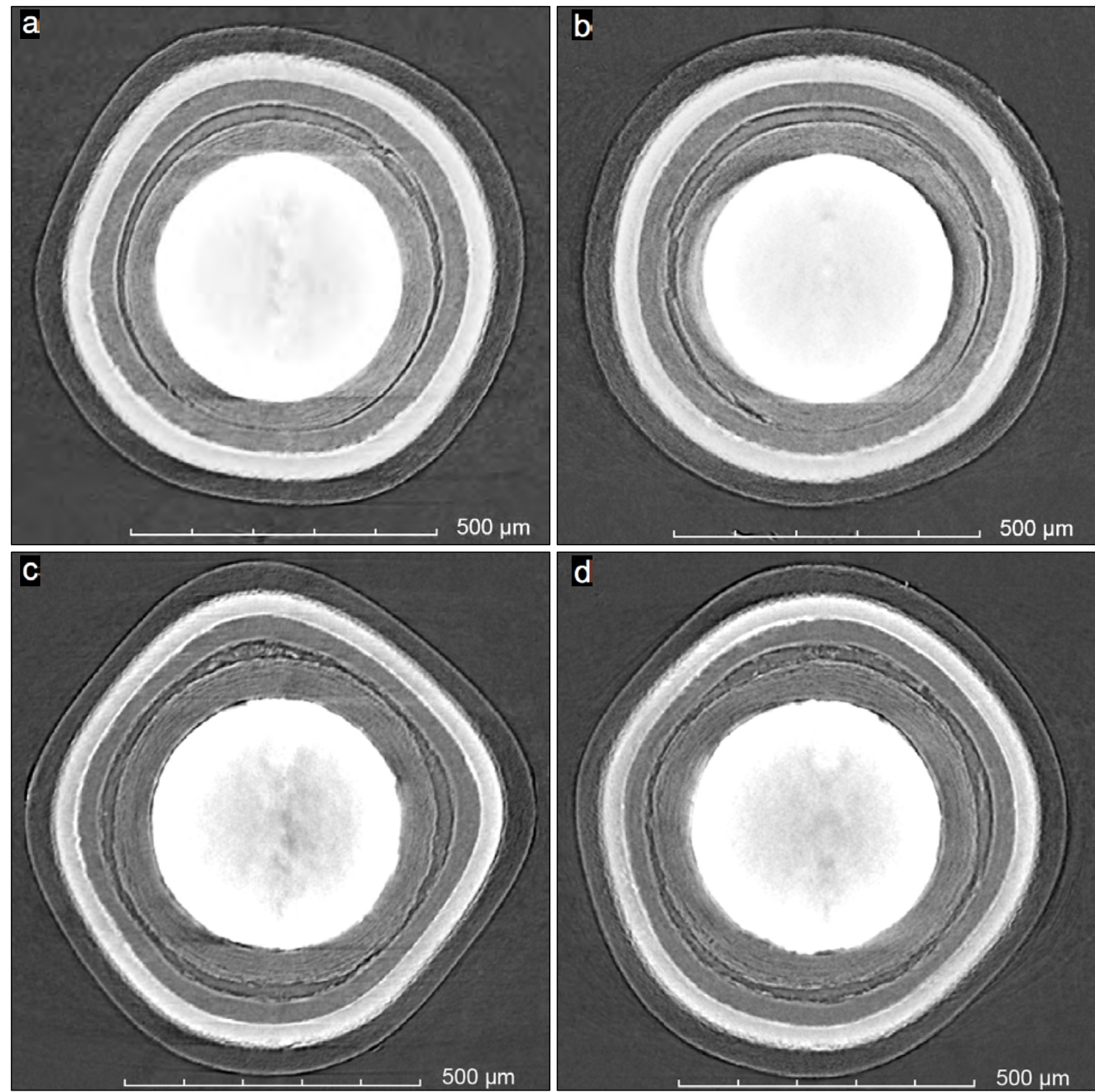

Figure 20. Orthogonal tomographs near midplane of Particle 511-RS03 (a and b) and Particle 511-RS05 (c and d) showing typical buffer shrinkage and delamination from IPyC. 
Two additional particles randomly-selected for IMGA measurement were ground and polished near midplane and imaged with optical microscopy. Particle 511-RS09 had an average radioisotopic inventory, except for ${ }^{110 \mathrm{~m}} \mathrm{Ag}$, which was below a detection limit of $\mathrm{M} / \mathrm{C}<0.61$; this particle also exhibited the common buffer shrinkage causing delamination from the IPyC and narrow gap between the $\mathrm{SiC}$ and OPyC (Figure 21).

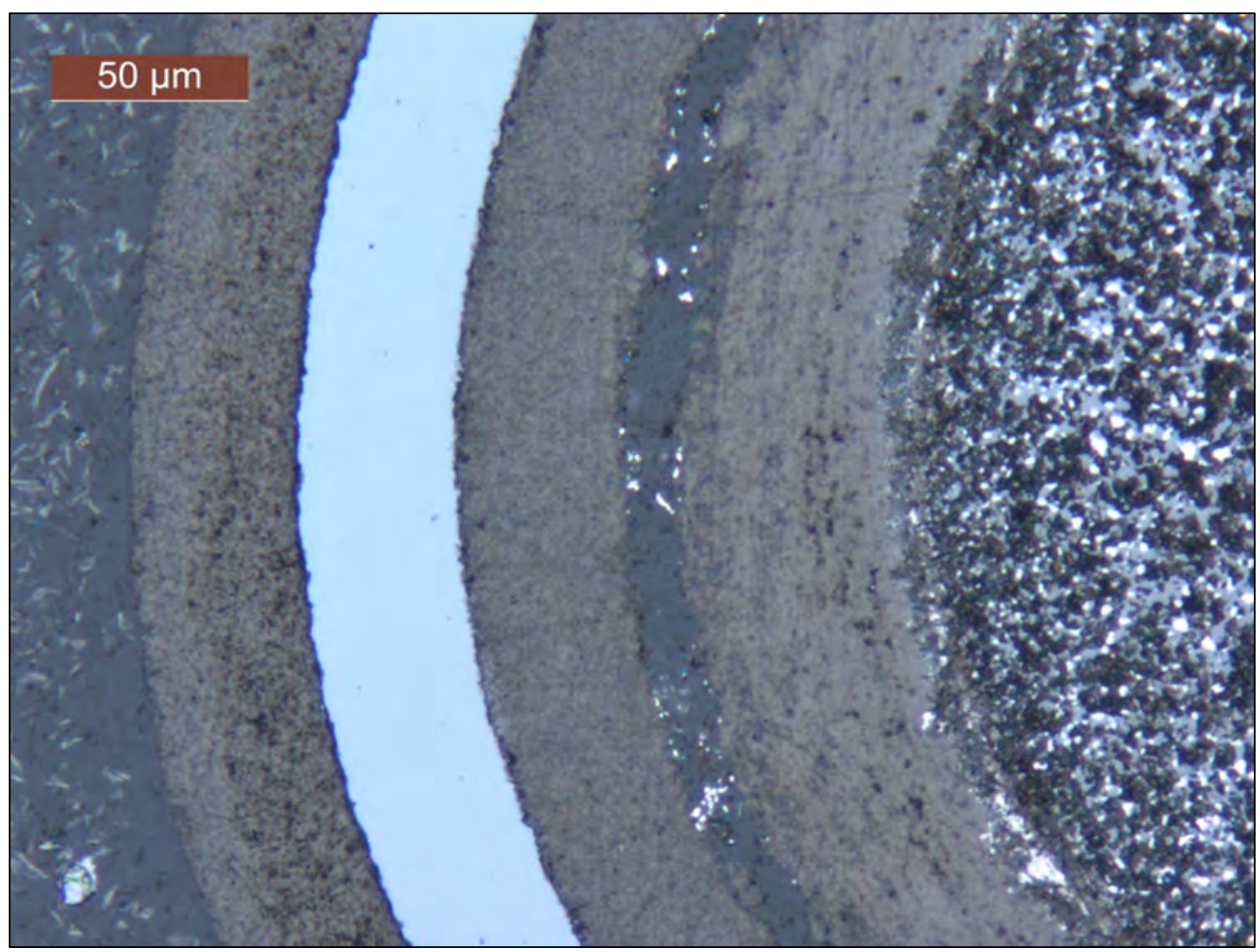

Figure 21. Optical micrograph near midplane of Particle 511-RS09 showing typical buffer shrinkage and delamination from IPyC. Backpot epoxy (gray) embedded with some bright fragments of kernel debris from the grinding process can be seen filling the gap between the buffer and IPyC layers. The apparent variation in porosity in the $\mathrm{OPyC}$ layer is a polishing artifact.

Particle 511-RS04 had an average radioisotopic inventory, including a ${ }^{110 \mathrm{~m}} \mathrm{Ag} \mathrm{M} / \mathrm{C}=1.01$. Figure 22 shows that this particle had a different internal microstructure than the other randomly-selected particles that were analyzed by x-ray or optical microscopy. Particle 511-RS04 had multiple fractures in the buffer layer accompanied by apparent complete debonding from the IPyC (at least in the single observed polish plane). This structure has been observed in other AGR-1 particles, and has been labeled as Type Af [Ploger et al. 2012]. Figure 22b and Figure 22c show several locations where cracks have formed in the IPyC layer, which appear to have been caused by the buffer as it tore away from the inner surface of the IPyC. In this single imaged plane, the IPyC cracks do not penetrate through to the SiC. There is also no evidence of fission product pileup, which is often observed near IPyC fractures in particles with degraded $\mathrm{SiC}$. 

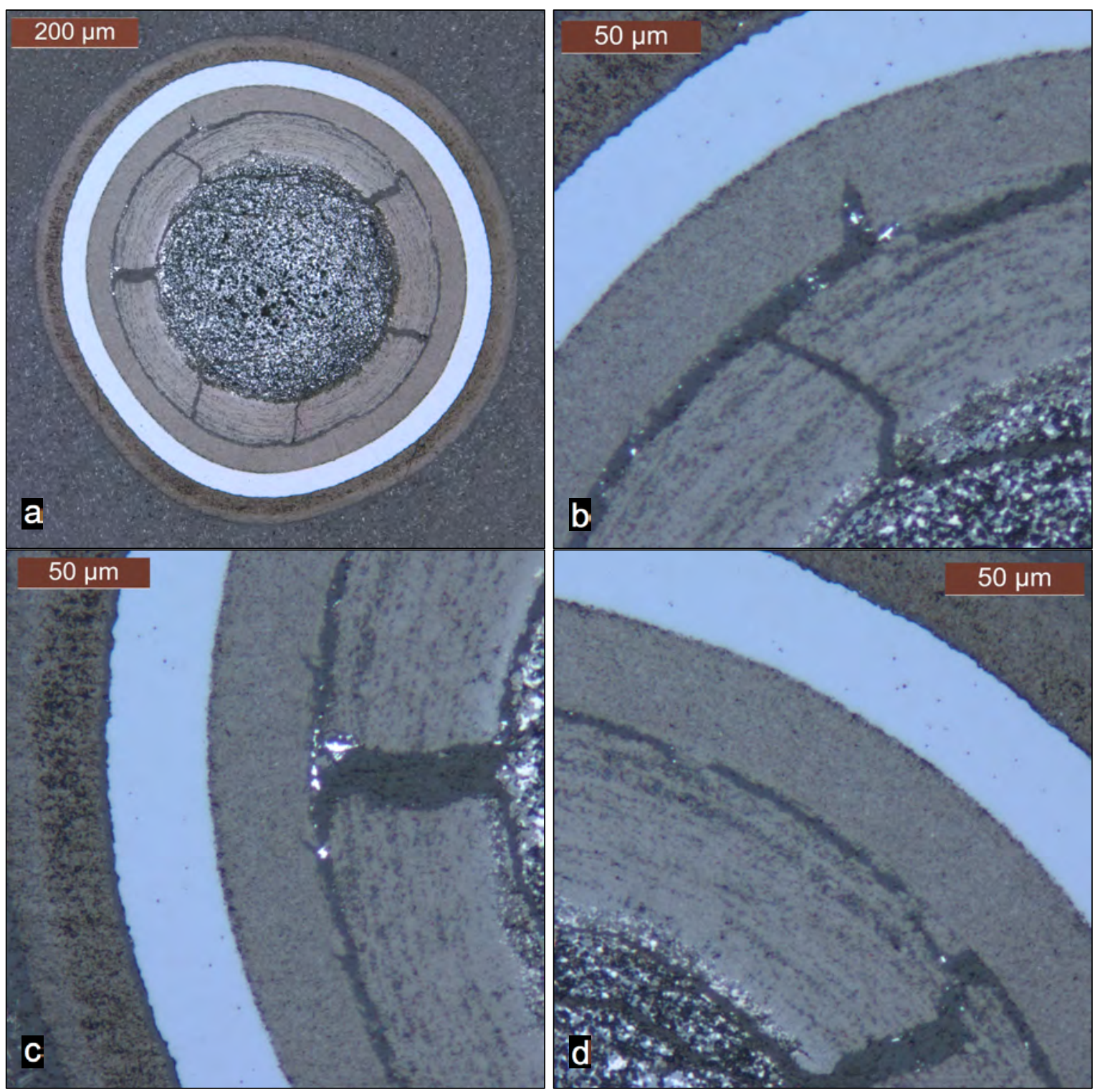

Figure 22. Optical micrographs near midplane of Particle 511-RS04 showing buffer fracture and some tearing in the IPyC that did not appear to penetrate the layer.

SEM analysis of randomly-selected particles was conducted on Particle 511-RS09 (M/C < 0.61), Particle 511-RS04 $(\mathrm{M} / \mathrm{C}=1.01)$, and Particle 511-RS37 $(\mathrm{M} / \mathrm{C}=1.48)$; these particles all had average radioisotopic inventories, but exhibited a variation in ${ }^{110 \mathrm{~m}} \mathrm{Ag}$ retention behavior. The overview images in Figure 23 show fission product features segregated in the IPyC layer and piled up at the IPyC/SiC interface, this is consistent with previous observations from SEM analysis of other safety-tested particles [Hunn et al. 2014-1; Hunn et al. 2014-3]. Figure 24 shows parallel image sets of the $\mathrm{SiC}$ layer for these three particles. Fission product features are again observed in the IPyC and piled up at the IPyC/SiC (more obvious in the BEC images), while the higher magnification also allows for identification of fission product features isolated in the $\mathrm{SiC}$ layer. The SEI analysis indicates the surfaces are free of debris and the local high-Z areas are truly embedded fission product features. A qualitative assessment indicates a greater frequency of fission product features distributed in the $\mathrm{SiC}$ layer of the particle with the lowest silver inventory (511-RS09) relative to the other two particles, which retained most of their silver. Fission product features were also observed deeper in the $\mathrm{SiC}$ layer, near the $\mathrm{SiC} / \mathrm{OPyC}$ interface, in the analysis of low-silver Particle 511-RS09. This trend for both higher concentration and observation of fission products throughout the thickness of the $\mathrm{SiC}$ layer in particles with low silver retention has been observed 
throughout the AGR-1 PIE campaign and is discussed in [Hunn et al. 2014-4] for particles from compacts safety tested at $1600^{\circ} \mathrm{C}$ and $1700^{\circ} \mathrm{C}$. It is worth noting that some variation in fission product concentration and distribution is also sometimes observed when comparing particles with high silver retention. Figure 24 shows that Particle 511-RS37 with the highest M/C value has more fission products in the $\mathrm{SiC}$ than Particle 511-RS04. Difference in fission product distribution in particles that have not yet released significant quantities of silver may simply indicate the progressive nature of the release.
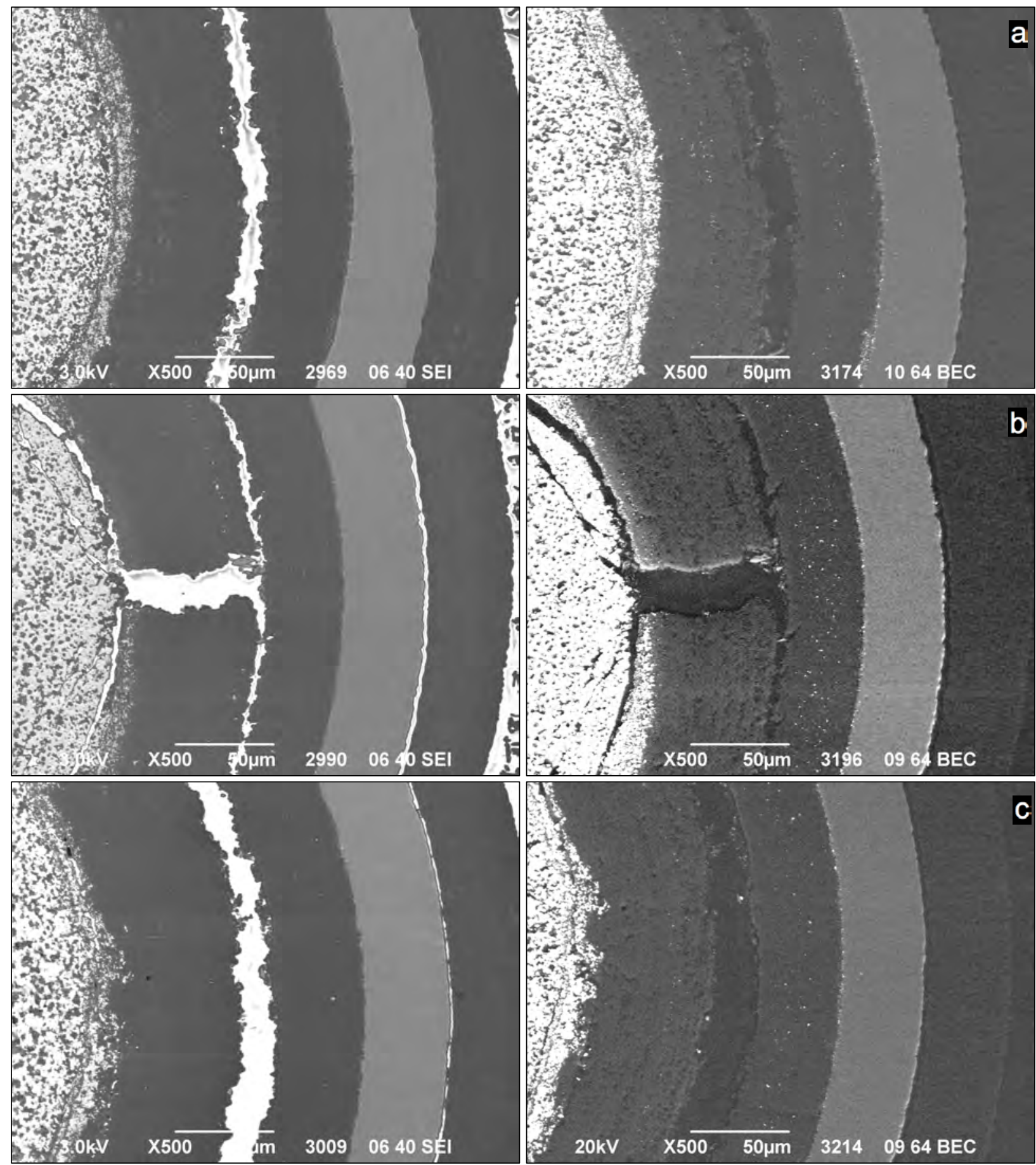

Figure 23. SEI/BEC-paired images presenting an overview of the TRISO layers of a) Particle 511-RS09 $(\mathrm{M} / \mathrm{C}<0.61)$, b) Particle 511-RS04 $(\mathrm{M} / \mathrm{C}=1.01)$, and c) Particle 511-RS37 $(\mathrm{M} / \mathrm{C}=1.48)$. Bright contrast between buffer and IPyC is from charging of backpot epoxy. 

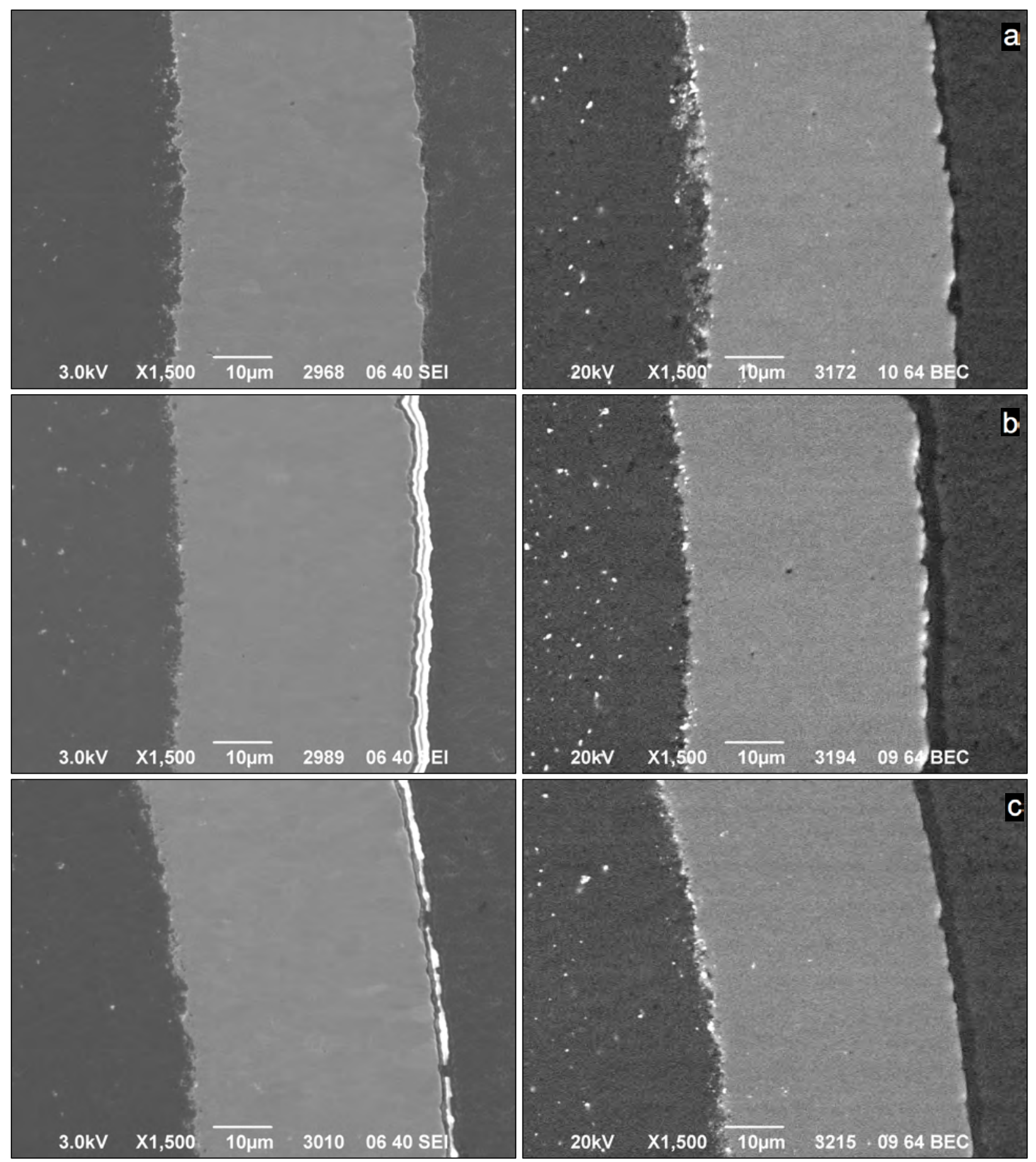

Figure 24. SEI/BEC-paired images of the SiC layer of a) Particle 511-RS09 (M/C < 0.61), b) Particle 511-RS04 (M/C = 1.01), and c) Particle 511-RS37 (M/C = 1.48).

Elemental analysis was conducted on select fission product features in the IPyC and SiC layer. High-Z clusters analyzed by EDS are indicated in Figure 25 for Particle 511-RS09 and Particle 511-RS04, the composition of the features is indicated by diamonds $(\mathrm{Pd})$ and squares $(\mathrm{U})$, with dashed lines indicating relatively-lower peak intensity. In the high-Ag release particle (511-RS09), palladium was found in every analyzed cluster within the $\mathrm{SiC}$ layer. Uranium was often observed collocated with the palladium in the clusters less than $10 \mu \mathrm{m}$ from the IPyC/SiC interface and sometimes in features further out into the SiC. The IPyC/SiC interface features in Particle 511-RS09 contained both uranium and palladium, with relatively-higher uranium content than clusters in the SiC. Particle 511-RS04, which released little to no 
silver, exhibited significantly fewer fission product clusters in the SiC. Limited quantities of palladium were observed, and features at the $\mathrm{IPyC} / \mathrm{SiC}$ interface were almost exclusively uranium-bearing. This comparison further corroborates the trend for particles with low silver retention exhibiting significant differences in palladium and uranium distribution within the $\mathrm{SiC}$ layer and at the IPyC/SiC interface. Other elements (not shown) were sometimes observed in the analyzed features located in the interlaced region between the IPyC and $\mathrm{SiC}$, or in spots in the IPyC layer away from the $\mathrm{SiC}$.
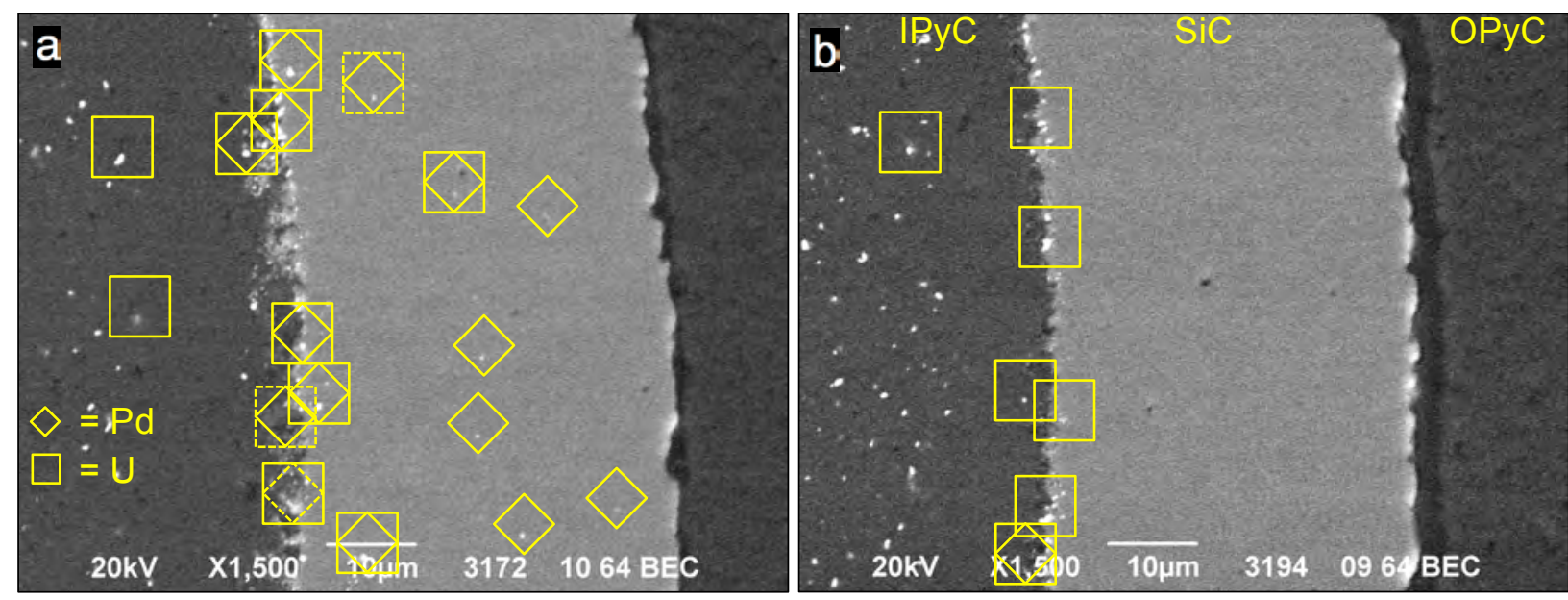

Figure 25. Backscattered-electron composition micrographs showing representative IPyC/SiC regions from a) Particle 511-RS09 with high ${ }^{110 \mathrm{~m}} \mathrm{Ag}$ release $(\mathrm{M} / \mathrm{C}<0.61)$, and b) Particle 511-RS04 with low ${ }^{110 \mathrm{~m}} \mathrm{Ag}$ release $(\mathrm{M} / \mathrm{C}=1.01)$. Dashed diamonds or squares indicate relatively lower signal.

\section{ENUMERATION OF PARTICLES WITH FAILED SIC}

Determination of the number of particles in each compact with failed $\mathrm{SiC}$ was discussed in a summary paper describing the detection and analysis of all the failed-SiC particles detected in AGR-1 irradiation testing and post-irradiation safety testing [Hunn et al. 2014-2]. The method was based on summing the amount of cesium released from the compact (measured with the CCCTF), the amount of exposed cesium still in the compact outside of intact SiC layers (measured by DLBL), and the amount of cesium retained by the particles with failed $\mathrm{SiC}$ that were separated out and measured with the IMGA. An accounting of the ${ }^{134} \mathrm{Cs}$ detected during Compact 5-1-1 safety testing and subsequent DLBL and IMGA indicates that all the particles that released cesium during safety testing were detected and sorted out during the IMGA survey. Table 7 shows that the ${ }^{134} \mathrm{Cs}$ released from the compact during safety testing, added to the residual exposed ${ }^{134} \mathrm{Cs}$ still in the compact after safety testing and the ${ }^{134} \mathrm{Cs}$ inventory remaining in the three low $\mathrm{Cs} / \mathrm{Ce}$ particles found by the IMGA sums to the average calculated ${ }^{134} \mathrm{Cs}$ inventory in three particles.

Table 7. Enumeration of particles with failed SiC based on recovery of ${ }^{134} \mathrm{Cs}$

\begin{tabular}{|l|c|}
\hline & Compact 5-1-1 \\
\hline \hline Number of particles worth of ${ }^{134} \mathrm{Cs}$ detected outside compact in CCCTF & 1.42 \\
Number of particles worth of ${ }^{134} \mathrm{Cs}$ detected outside intact SiC by DLBL & 0.26 \\
\hline Number of particles worth of ${ }^{134} \mathrm{Cs}$ retained in three low Cs/Ce particles found with IMGA & 1.32 \\
\hline Total number of particles worth of ${ }^{134} \mathrm{Cs}$ presumed to be associated with failed $\mathrm{SiC}$ & 3.00 \\
Estimated number of particles with failed SiC based on IMGA survey and x-ray & $\mathbf{3}$ \\
\hline
\end{tabular}




\section{SUMMARY AND CONCLUSIONS}

This report summarizes the safety testing and post-safety testing PIE of AGR-1 Compact 5-1-1. Safety testing was performed at $1700^{\circ} \mathrm{C}$ and this was the fourteenth and last AGR-1 safety tests performed in the ORNL CCCTF. Post-safety testing PIE consisted of DLBL, IMGA, x-ray tomography, and mechanical cross sectioning followed by optical and electron microscopy. Data was obtained on radioisotope retention and microstructural changes that occurred during irradiation and the subsequent safety testing.

Three particles experienced $\mathrm{SiC}$ failure during safety testing (Table 7). These three particle released a significant fraction of their cesium, which is not well-retained by the carbon layers, and a few percent of their krypton, which can slowly diffuse through gas-tight carbon layers at $1700^{\circ} \mathrm{C}$ (Table 2). Silver, europium, and strontium were released at levels above what would come from just the three particles with failed $\mathrm{SiC}$ (Figure 1). Silver was released rapidly as the compact was heated to $1700^{\circ} \mathrm{C}$ and little silver was released later in the test (Figure 3), which indicates this silver was already outside of the intact $\mathrm{SiC}$ layers at the start of the safety test. Europium and strontium were released more slowly and at an almost constant rate while at $1700^{\circ} \mathrm{C}$ (Figure 2 and Figure 3). This release may also have been dominated by inventory already outside of the intact $\mathrm{SiC}$ layers at the start of the safety test, given the fact that these elements move slowly through the matrix at $1700^{\circ} \mathrm{C}$ and similar exposed levels of europium and strontium have been measured in as-irradiated compacts [Demkowicz et al. 2014]. However, it cannot be ruled out that some measurable amount of the detected europium and strontium may have come through the $\mathrm{SiC}$ during the safety test, and safety testing at $1800^{\circ} \mathrm{C}$ provides additional evidence that this may be occurring [Hunn et al. 2013-4]. The overall $1700^{\circ} \mathrm{C}$ safety test performance of Compact 5-1-1 was very similar to $1700^{\circ} \mathrm{C}$ safety-tested Compact 3-1-1 in terms of fission product release [Hunn et al. 2012-1] and number of $\mathrm{SiC}$ failures (four in Compact 3-3-1) [Hunn et al. 2013-2]. Compact 5-1-1 safety test performance also fell in between that observed for the other two Capsule 5 Variant 1 compacts tested at $1600^{\circ} \mathrm{C}$ and $1800^{\circ} \mathrm{C}$ (Table 2).

The three particles from Compact 5-1-1 with failed $\mathrm{SiC}$ were successfully detected and sorted out with IMGA for further analysis. The OPyC layer in one particle was damaged during deconsolidation, resulting in acid leaching of most of the kernel, but x-ray tomography of the leached particle showed it to be an as-fabricated defect (Figure 8). This was the third AGR-1 particle identified with a failed SiC layer due to an as-fabricated defect; the other two were found after $1600^{\circ} \mathrm{C}$ safety testing of Compact 3-3-2 [Hunn et al. 2012-2] and Compact 4-1-2 [Hunn et al 2013-3]. All three of the PIE-observed AGR-1 asfabricated defects were due to fluidization anomalies during coating.

The other two Compact 5-1-1 particles with SiC failure (Figure 10 and Figure 16) exhibited the same degradation mechanism that has been observed in all the other AGR-1 particles with SiC failure during irradiation or safety testing [Hunn et al. 2014-2]. In these particles, dimensional changes in the buffer and kernel due to buffer densification and kernel expansion led to cracking of the IPyC layer. Two general mechanisms for IPyC cracking were buffer fracture propagating directly into an attached IPyC layer and buffer layer delamination resulting in damage to the IPyC as the buffer layer was tearing away. IPyC cracks did not always result in $\mathrm{SiC}$ failure, but $\mathrm{SiC}$ failure appeared to always be related to IPyC cracking. Exposure of the $\mathrm{SiC}$, either along the edge of the IPyC crack or where the IPyC crack led to delamination at the IPyC/SiC interface, allowed fission products (predominantly palladium and uranium) to pileup and react with the $\mathrm{SiC}$ layer. Degradation of the exposed $\mathrm{SiC}$ eventually resulted in a localized penetration of the layer. Removal of silicon along this penetration pathway left behind a low-density, C-rich material through which cesium could escape. Elemental mapping of the degraded SiC in Particle 511-SP03 showed large regions in the $\mathrm{SiC}$ that were $\mathrm{C}$-rich and Si-poor (Figure 14). This particle also exhibited previously unobserved pileup of fission products (mainly ruthenium and uranium) in the OPyC layer adjacent to the $\mathrm{SiC}$ degradation (Figure 11f), as well as unusual concentrations of molybdenum in the kernel protrusion closest to the $\mathrm{SiC}$ degradation (on the other side of the $\mathrm{SiC}$ ).

While the degradation of the SiC occurred at high temperature during the post-irradiation safety testing, structural changes observed in randomly-selected Compact 5-1-1 particles examined after safety testing 
probably occurred during the irradiation before the safety test. Microstructures observed in randomlyselected particles extracted from Compact 5-1-1 after safety testing were similar to those seen in asirradiated fuel [Ploger, Demkowicz, and Hunn 2012; Hunn, Savage, and Kehn 2012; Hunn et al. 2013-1; Hunn et al. 2014-3]. Shrinkage of the buffer layer and swelling of the kernel were common to all particles. Most of the randomly-selected particles from Compact 5-1-1 showed complete delamination between the buffer and IPyC (Figure 20), and only one particle had a fractured buffer (Figure 22). None of these microstructures seemed to be directly related to the varied amount of silver released from the particles selected for examination. The large variation in silver retention observed in the randomlyselected particles from Compacts 5-1-1 (Figure 7) was similar to that observed in other AGR-1 compacts and is believed to be primarily related to particle temperature, which varied as a function of both time and position within each compact over the three-year irradiation test [Demkowicz et al. 2014].

SEM imaging and EDS analysis of the SiC layers in randomly-selected particles showed palladium and uranium were piled up in clusters at the $\mathrm{IPyC} / \mathrm{SiC}$ interface and within the $\mathrm{SiC}$ layer itself (Figure 25). Particle 511-RS09 exhibited lower retention of ${ }^{110 \mathrm{~m}} \mathrm{Ag}$ and had numerous clusters of palladium scattered throughout the layer, while particles with ${ }^{110 \mathrm{~m}} \mathrm{Ag}$ inventories higher than the calculated average had $\mathrm{SiC}$ layers relatively void of palladium clusters more than $10 \mu \mathrm{m}$ away from the IPyC/SiC interface. Uranium tended to be constrained to clusters close to the IPyC/SiC interface, and uranium in the $\mathrm{SiC}$ was collocated with palladium. These trends for palladium and uranium distribution in the SiC layer were consistent with those observed in as-irradiated compacts (Hunn et al. 2013-1; Hunn et al. 2014-3) and other safety-tested compacts [Hunn et al. 2014-4].

\section{ACKNOWLEDGMENTS}

This work was supported by the U.S. Department of Energy, Office of Nuclear Energy, under the INL Advanced Reactor Technologies Technology Development Office/Advanced Gas Reactor Fuel Development and Qualification Program. Analysis of leach solutions and CCCTF furnace components was provided by the ORNL Nuclear Analytical Chemistry \& Isotopics Laboratory. Hot cell activities were supported by the staff of the ORNL Irradiated Fuels Examination Laboratory (IFEL).

\section{REFERENCES}

Baldwin, C.A., P.A. Demkowicz 2012. "First Elevated Temperature Performance Testing of Coated Particle Fuel Compacts from the AGR-1 Irradiation Experiment." Paper HTR2012-3-027. Proceedings of the HTR 2012. Tokyo, Japan October 28-November 1, 2012.

Collin, B.P. 2015. AGR-1 Irradiation Test Final As-Run Report. INL/EXT-10-18097, Rev. 3. Idaho National Laboratory, Idaho Falls, ID.

Demkowicz, P.A., L.T. Cole, S.A. Ploger, and P.L. Winston 2010. "AGR-1 Irradiation test Train Preliminary Inspection and Disassembly First Look." INL/EXT-10-20722. Idaho National Laboratory, Idaho Falls, ID.

Demkowicz, P.A., J.D. Hunn, S.A. Ploger, R.N. Morris, C.A. Baldwin, J.M. Harp, P.L. Winston, T.J. Gerczak, I.J. van Rooyen, F.C. Montgomery, and C.M. Silva 2014. "Irradiation Performance of AGR-1 High Temperature Reactor Fuel." Paper HTR2014-31182. Proceedings of the HTR 2014. Weihai, China, October 27-31, 2014.

Harp, J.M. 2013. Analysis of Individual Compact Fission Product Inventory and Burnup of the AGR-1 TRISO Experiment Using Gamma Spectrometry. INL/ECAR-1682, Rev. 2. Idaho National Laboratory, Idaho Falls, ID.

Hunn, J.D., and R.A. Lowden 2006. Data Compilation for AGR-1 Variant 1 Coated Particle Composite LEU01-47T. ORNL/TM-2006/020, Rev. 1. Oak Ridge National Laboratory, Oak Ridge, TN.

Hunn, J.D., F.C. Montgomery, and P.J. Pappano 2006. Data Compilation for AGR-1 Variant 1 Compact Lot LEU01-47T-Z. ORNL/TM-2006/508. Oak Ridge National Laboratory, Oak Ridge, TN. 
Hunn, J.D., T.W. Savage, and J.S. Kehn 2012. AGR-1 Irradiated Compact 6-4-2 PIE Report: Preparation and Analysis of Polished Compact Sections. ORNL/TM-2012/285. Oak Ridge National Laboratory, Oak Ridge, TN.

Hunn, J.D., T.W. Savage, and C.M. Silva 2012. AGR-1 Fuel Compact Pre-Irradiation Characterization Summary Report. ORNL/TM-2012/295. Oak Ridge National Laboratory, Oak Ridge, TN.

Hunn, J.D., R.N. Morris, C.A. Baldwin, F.C. Montgomery 2012-1. Summary of Safety Test on Irradiated AGR-1 Compact 3-3-1. ORNL/LTR-2012/926. Oak Ridge National Laboratory, Oak Ridge, TN.

Hunn, J.D., R.N. Morris, C.A. Baldwin, F.C. Montgomery, and C.M. Silva 2012-2. PIE on Five Irradiated AGR-1 Compacts. ORNL/LTR-2012/397. Oak Ridge National Laboratory, Oak Ridge, TN.

Hunn, J.D., R.N. Morris, C.A. Baldwin, F.C. Montgomery, C.M. Silva, and T.J. Gerczak 2013-1. AGR-1 Irradiated Compact 4-4-2 PIE Report: Evaluation of As-Irradiated Fuel Performance with Leach Burn Leach, IMGA, Materialography, and X-ray Tomography. ORNL/TM-2013/236. Oak Ridge National Laboratory, Oak Ridge, TN.

Hunn, J.D., R.N. Morris, C.A. Baldwin, F.C. Montgomery, C.M. Silva, and T.J. Gerczak 2013-2. PIE on Three Irradiated AGR-1 Compacts in FY2013. ORNL/LTR-2013/291. Oak Ridge National Laboratory, Oak Ridge, TN.

Hunn, J.D., R.N. Morris, C.A. Baldwin, and F.C. Montgomery 2013-3. Safety Tests on Irradiated AGR-1 Compacts 4-1-2, 4-4-3, and 4-4-1. ORNL/LTR-2013/290. Oak Ridge National Laboratory, Oak Ridge, TN.

Hunn, J.D., R.N. Morris, C.A. Baldwin, F.C. Montgomery 2013-4. Safety Tests on Irradiated AGR-1 Compacts 5-3-3 and 5-1-3. ORNL/LTR-2013/603. Oak Ridge National Laboratory, Oak Ridge, TN.

Hunn, J.D., R.N. Morris, C.A. Baldwin, F.C. Montgomery, and T.J. Gerczak 2014-1. PIE on SafetyTested AGR-1 Compacts 5-3-3, 5-1-3, and 3-2-3. ORNL/TM-2014/484. Oak Ridge National Laboratory, Oak Ridge, TN.

Hunn, J.D., C.A. Baldwin, T.J. Gerczak, F.C. Montgomery, R.N. Morris, C.M. Silva, P.A. Demkowicz, J.M. Harp, S.A. Ploger, I.J. van Rooyen, and K.E. Wright 2014-2. "Detection and Analysis of Particles with Failed SiC in AGR-1 Fuel Compacts." Paper HTR2014-31254. Proceedings of the HTR 2014. Weihai, China, October 27-31, 2014.

Hunn, J.D., C.A. Baldwin, T.J. Gerczak, F.C. Montgomery, R.N. Morris, and C.M. Silva 2014-3. AGR-1 Irradiated Compacts 5-2-3 and 5-2-1 PIE Report: Evaluation of As-Irradiated Fuel Performance with Leach Burn Leach, IMGA, Materialography, and X-ray Tomography. ORNL/TM-2014/171. Oak Ridge National Laboratory, Oak Ridge, TN.

Hunn, J.D., R.N. Morris, C.A. Baldwin, F.C. Montgomery, and T.J. Gerczak 2014-4. PIE on SafetyTested AGR-1 Compacts 4-1-2 and 4-4-3. ORNL/LTR-2014/101. Oak Ridge National Laboratory, Oak Ridge, TN.

Kercher, A.K., and J.D. Hunn 2005. Results from ORNL Characterization of Nominal $350 \mu \mathrm{m}$ LEUCO Kernels from the BWXT G73D-20-69302 Composite. ORNL/TM-2005/517. Oak Ridge National Laboratory, Oak Ridge, TN.

Ploger, S.A., P.A. Demkowicz, and J.D. Hunn 2012. Ceramographic Examinations of Irradiated AGR-1 Fuel Compacts. INL/EXT-12-25301, Rev. 1. Idaho National Laboratory, Idaho Falls, ID.

Sterbentz, J.W. 2013. JMOCUP As-Run Daily Depletion Calculation for the AGR-1 Experiment in ATR B-10 Position. INL/ECAR-958, Rev. 2. Idaho National Laboratory, Idaho Falls, ID. 